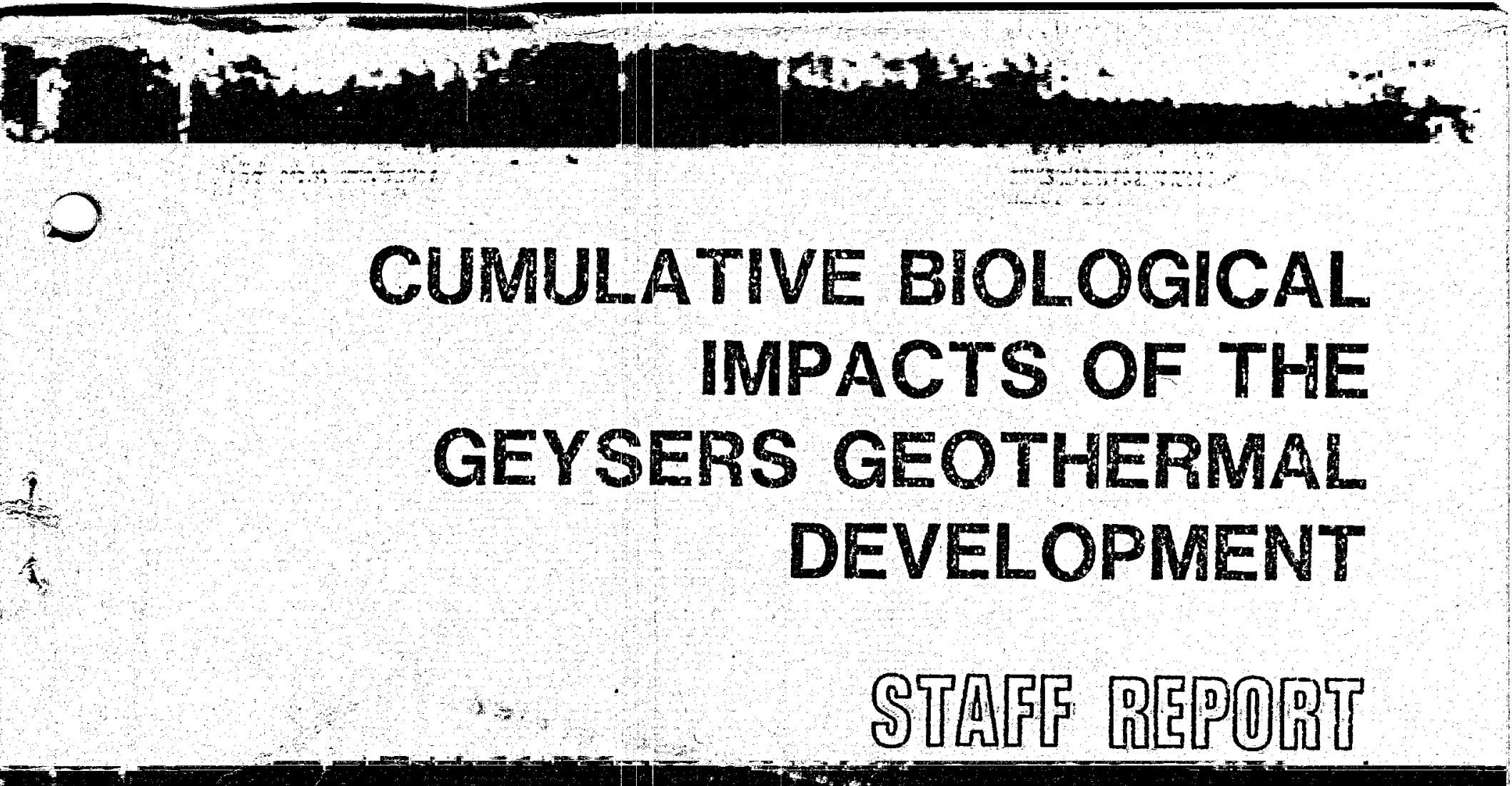

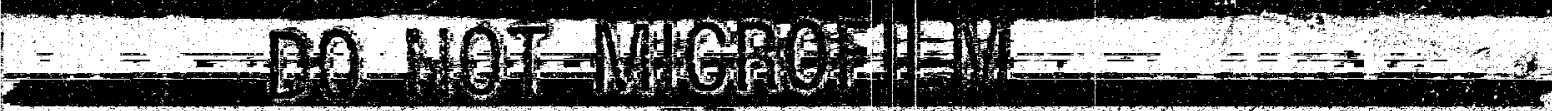

2 COVER

OCTOEER 1981

$\frac{1}{1}$

\author{
CALIFORNIA \\ ENERGY \\ COMMISSION
}

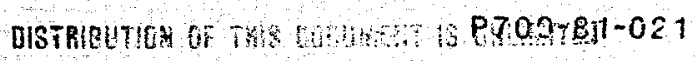




\section{DISCLAIMER}

This report was prepared as an account of work sponsored by an agency of the United States Government. Neither the United States Government nor any agency Thereof, nor any of their employees, makes any warranty, express or implied, or assumes any legal liability or responsibility for the accuracy, completeness, or usefulness of any information, apparatus, product, or process disclosed, or represents that its use would not infringe privately owned rights. Reference herein to any specific commercial product, process, or service by trade name, trademark, manufacturer, or otherwise does not necessarily constitute or imply its endorsement, recommendation, or favoring by the United States Government or any agency thereof. The views and opinions of authors expressed herein do not necessarily state or reflect those of the United States Government or any agency thereof. 


\section{DISCLAIMER}

Portions of this document may be illegible in electronic image products. Images are produced from the best available original document. 


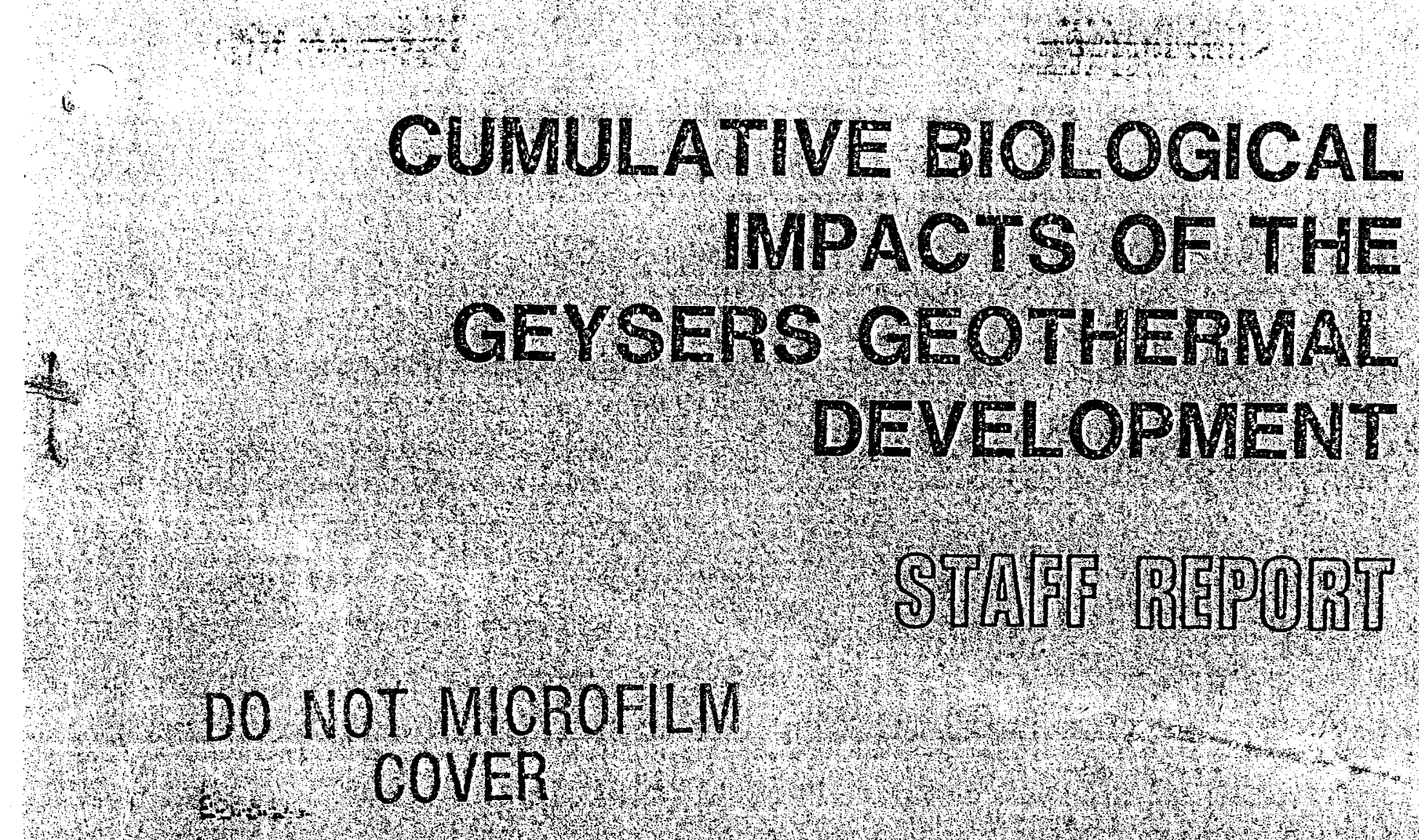

\%

\section{CUMULATIVE BIOLOGICAL IMPACTS OF THE GEYSERS GEOTHERMAL}

\section{DO NOT MICROFLLM 3.t.}

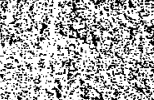

H. W W

3
3

OCTOBER 1981

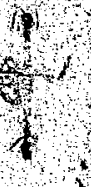

\section{CALIFORINIA ENERGY COMMISSION}




\title{
CUMULATIVE BIOLOGICAL IMPACTS \\ OF THE GEYSERS GEOTHERMAL DEVELOPMENT
}

STAFF REPORT

CALIFORNIA ENERGY COMMISSION

. OCTOBEER 1981

$$
\mathrm{P}--700-81-021
$$

DE83 901357

\author{
JAMES A. BROWNELL, PH.D \\ PRINCIPAL AUTHOR
} ROBERT THERKELSEN, MANAGER ENVIRONMENTAL AND HEALTH OFFICE

E, ROSS DETER, CHIEF ENGINEERING AND ENVIRONMENTAL DIVISION 


\section{ACKNOWLEDGMENTS}

The author would 11ke to acknowledge contributions made to this report by division staff, particularly Gary Gomby for the preliminary analysis of 1mpacts and preparation of the draft for the impacts portions of the report and contributions by Richard Anderson, Jim Nelson, and Marc Sazaki. Graphics were provided by Tino Flores and Thom Lewls and maps by Alan Taylor and Yorick Lutes.

The report was critically revlewed and suggestions for improvements in the text were made by Bob Haussler, Biology and Water Resources Unit Manager; Bob Therkelsen, Office Manager, Environmental and Health Office; and B1II Durkee, Deputy Division Chief.

The original report was typed by Tracy Werhan, with report revisions and final draft typed by the Word Processing staff. 



\section{Preface}

This report reviews studies on both current and potential future cumulative biological impacts that may result from development of the dry steam resource at The Geysers-Calistoga KGRA and Identifies the CEC staff position on related issues and their proposed solutions. 



\section{ABSTRACT}

The cumulative nature of current and potential future biological impacts from full geothermal development in the steam-dominated portion of The GeysersCalistoga KGRA are Identifled by the California Energy Commission staff. Vegetation, wildife, and aquatic resources information have been reviewed and evaluated. Impacts and their significance are discussed and staff recommendat1ons presented.

Development of 3,000 MW of electrical energy will result in direct vegetation losses of 2,790 acres, based on an estimate of 11.5 percent loss per leasehold or 0.93 acres/MW. If unmitigated, losses will be greater. Indirect vegetation losses and damage occur from steam emissions which contain elements (particularly boron) toxic to vegetation. Other potential impacts include chronic low-level boron exposure, acld raln, local climate modification, and mechanical damage.

A potential exists for significant reduction and changes in wildife from direct habitat loss and development influences.

Highly erosive solls create the potential for significant reduction of aquatic resources, particularly game fish. Toxic spills have caused some temporary losses of aquatic species. Staff recommends monitoring and implementation of mitigation measures at all geothermal development stages. 



\section{Page}

List of figures ..................... xili

List of Tables ..................... xv

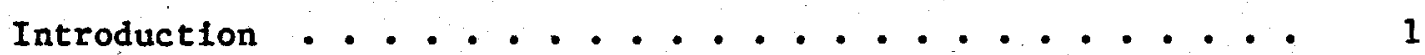

Purpose .................... . . 1

Background . . . . . . . . . . . . . 3

Overvlew of Geothermal Resource . . . . . . 9

Size of the Steam Reservolr .......... 9

Generating Capacity Scenarios . . . . . . . 12

Cumulative Vegetation Impacts

Introduction ................ 16

Rare and Endangered Plants ....................... 16

Staff Position ................. 17

Proposed Solutions . . . . . . . . 17

Direct Vegetation Loss . . . . . . . . . . . . 18

Staff Position ........................ 24

Proposed Solutions . . . . . . . . . 24

IndIrect Impacts to Vegetation . . . . . 25

Cooling Tower Drift . . . . . . . 25

Hydrogen Sulfide Emissions . . . . . 34

Acld Rain Formation ................... 35

Climate Modification . . . . . . 36

Mechantcal Damage . . . . . . . . 36

Staff Postion .................. 36

Proposed Solutions ............... 37 
Cumulative Wildife Impacts

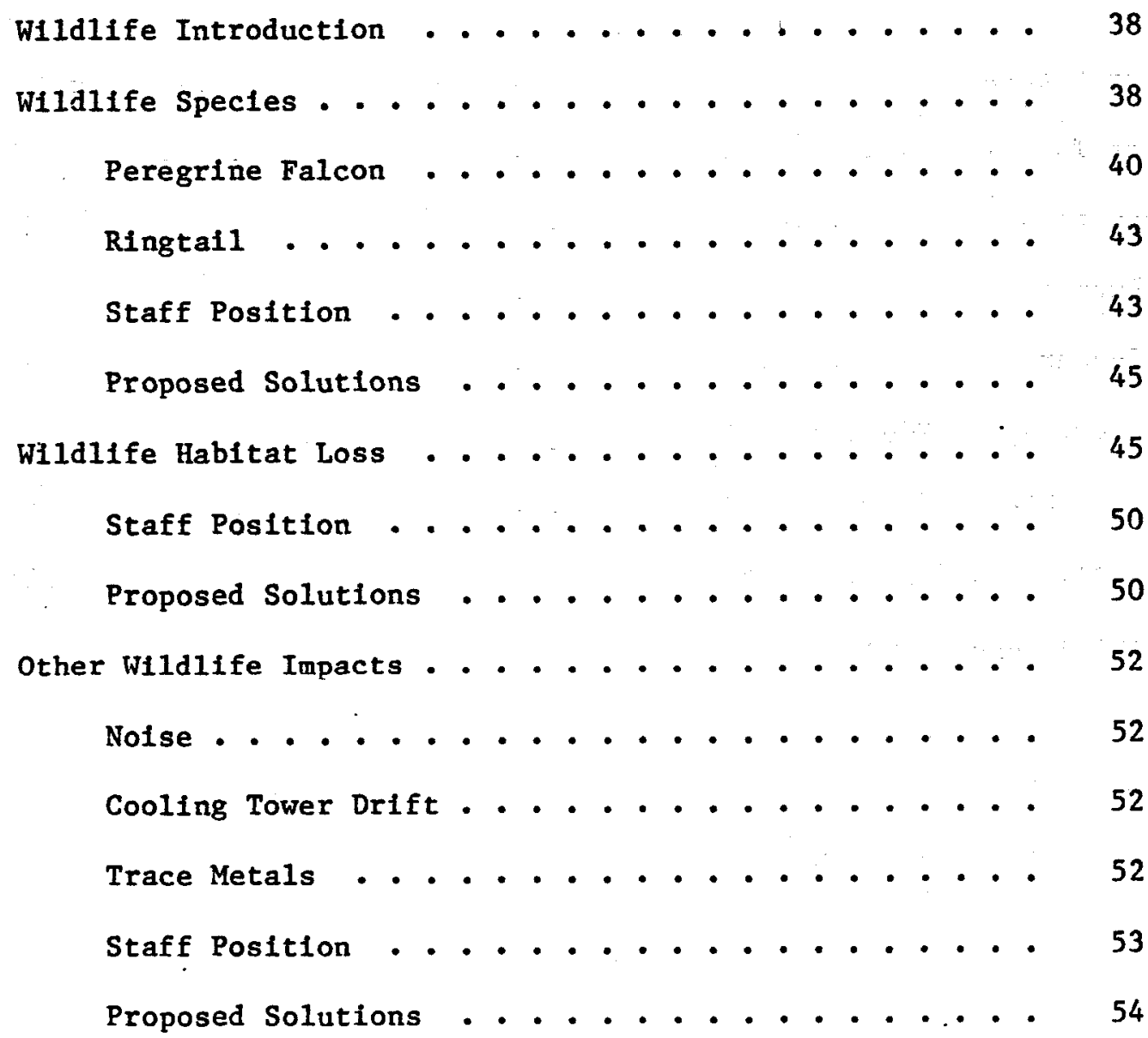

Cumulative Aquatic Biota Impacts

Erosion and Sedimentation ............ 56

Consequences of Vegetation Removal . . . . . . 56

Impacts on Aquatic Biota ............. 59

Impacts of Sedimentation ............ 63

Impacts of Chemical Discharges ......... 55

Staff Position ................... 66

Proposed Solutions ............. 67

Injection .................... 68

Staff Position ................ 69 


\section{Page}

Proposed Solutions ..............

Sumnary and Conclusions

Sumary . . . . . . . . . . . . . 72

Vegetation ................. 72

Wildllfe ...................... 74 ,

Aquatic Blota .................. 76

Conclusions ................... 78

References .................... 80

Appendices

A. Plant Communities of the KGRA and Their

Characteristic specles ............

B. Rare and Endangered Vascular Plants of The Geysers KGRA, Status and Blooming Time ......... 102

C. Vertebrate AnImals of The Geysers KGRA . . . . 132

D. Listing of Pollution Incidents at The Geysers Geothermal Field . . . . . . . . . 141 
1 Flow Chart of Environmental Disruption

Due to Geothermal Development . . . . . . . .

2 KGRA and Surrounding Count1es ............ 4

3 Dry Steam Resource Area . . . . . . . . . . 5

4 The Geysers Development Area . . . . . . . . 6

5 Geologic Map of The Geysers-Clear Lake Region ..... 10

6 Cross-Section Through The Geysers--Clear Lake Region .....................

7 Acres of Vegetation Loss Per Cumulative Megawatt of Power Generated . . . . . . . . . . •

8 The Area of Stressed Vegetation Around Geysers Units $1-6$ in $1973-1978 \ldots . . . . . .$.

9 The Area of Stressed Vegetation Around Geysers Units $7-11$ in $1973-1978 \ldots . . . . . . .$.

10 Mean Annual Boron Concentrations in Circulating Water for Geysers Units $1-11 \ldots . . . .$.

11 Peregrine Falcon Critical Habitat Zone ....... 42

12 Map Showing Solls With High Erosion Potential . . . . 57

13 Surface Hydrology Map . . . . . . . . . . 62

$$
\operatorname{xi1i} / x i v
$$


6 
TABLES

Table

1 Geothermal Power Plant Development in The Geysers KGRA 1960 - 1990 . . . . . . . . .

2 Land Use Requirements for a Typical Geothermal Development Site ................ 19

3 Estimated Vegetation Loss .............. 21

4 Cumulative Vegetation Loss Estimates . . . . . . 23

5 Vegetation Damaged by Cooling Tower Drift . . . . . 27

6 Annual Extent of Stressed Vegetation Around PG\&E Unfts 1 - 11 During 1973 - 1978 . . . . . 30

7 Preliminary List of Rare, Endangered, and Protected Wildlife Spectes of The KGRA . . . . . 39

8 Predominant Vegetation Habitat Types Adjacent to Power Plants in The Geysers KGRA ......... 46

9 Food and Habitat Requirements of Game Species

Found in The Geysers KGRA ............ 47

10 Summary of The Geysers Wildlife Study: Preliminary Results . . . . . . . . . 49

11 Terrain Analysis of Geothermal Wells .......... 60

12 Terrain Analysis of Geothermal Power Plants .. . . . 61

13 Geothermal Development In KGRA Watersheds . . . . 64 
INTRODUCTION

PURPOSE

This report documents the cumulative blological resources impacts that have occur.red in The Geysers KGRA steam-dominated area and projects the impacts that w111 occur if development proceeds according to three projected energy development scenarios: Rather than attempting an exhaustive categorization and discussion of every real and potential cumulative blological resource impact, this investigation identifies those impacts on 1and, a1r, and water which in turn affect flora and fauna (Figure 1). The discussion of biological resource impacts focuses on the following areas: (1) direct habitat loss (1.e., vegetation) due to construction; (2) indirect vegetation loss and damage due to cooling tower emissions; and (3) wildlife and aquatic resource (particularly game fish) Impacts due to construction and operation activities. The report summarizes relevant literature, identifies problem areas that will require additional information for resolution, Identifies issues which should be addressed by geothermal policy makers, and presents the Commission's biological resources staff position on these concerns.

This report is the first product of a three-phase program to address the cumulative biological resource impacts in The Geysers steam resource area. The second phase is a series of blological constraints maps covering the geothermal area. The third phase will involve development of regional mitigation, compensation, and management plans. Each of the products is likely to be used by developers to plan projects and by federal, state, and local permitting agencies to provide guidance in policy and siting decisions. If implemented, these plans will reduce the potential for cumulative biological 


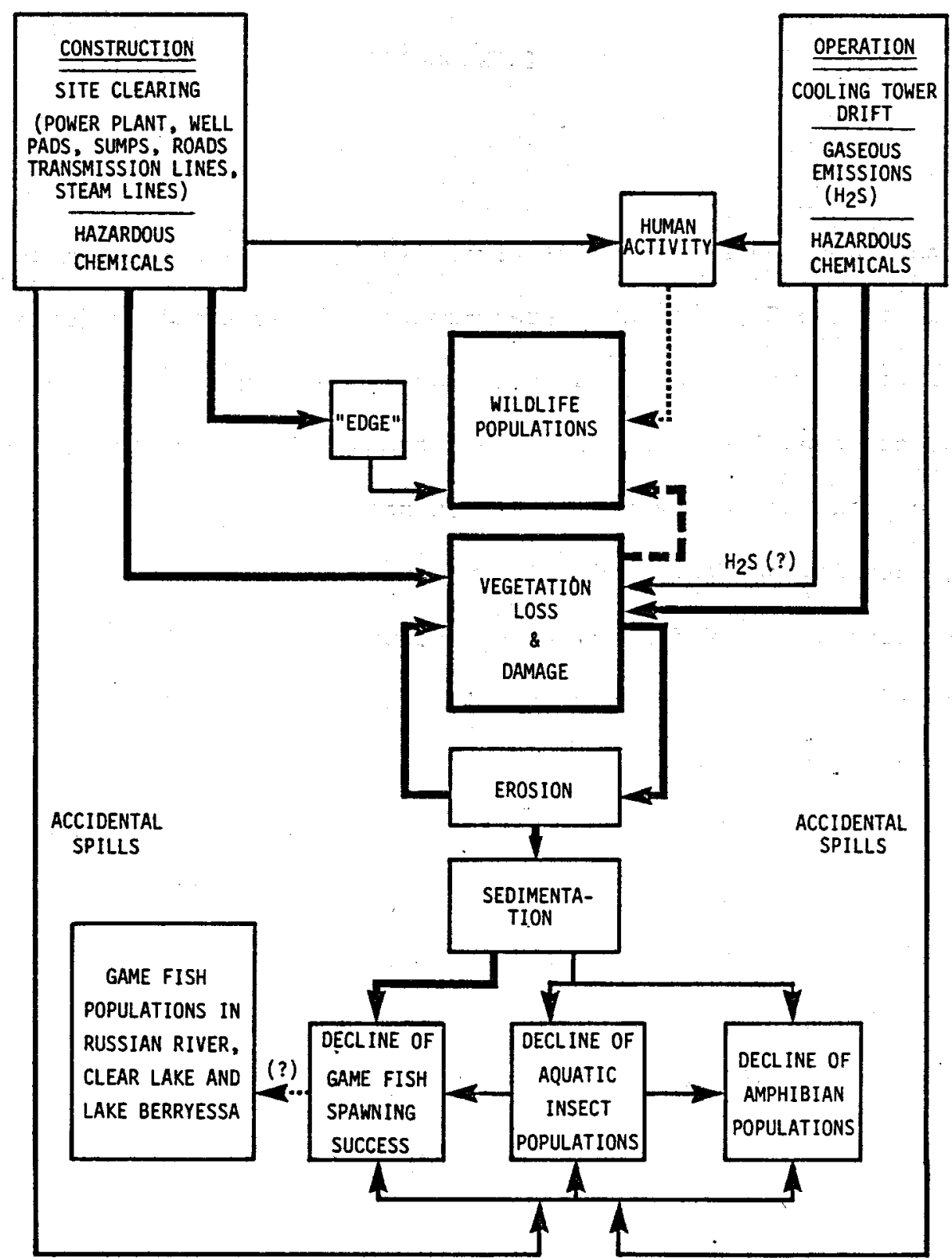

MAJOR INCREASE

MINOR INCREASE

MAJOR DECREASE $=m-m$ MINOR DECREASE
FLOW CHART DEPICTS IMPACTS TO BIOLOGICAL RESOURCES STEMMING FROM GEOTHERMAL DEVELOPMENT. CONSTRUCTION AND OPERATION ACTIVITIES HAVE AN INCREASING EFFECT OR DEPRESSING EFFECT ON BIOLOGICÁ́ RESOURCES: E.G., CONSTRUCTION ACTIVITIES INCREASE VEGETATION LOSS AND DAMAGE, WHICH IN TURN INCREASES EROSION. QUESTION MARKS (?) INDICATE THAT THE EFFECT OF THE ACTIVITY IS UNCERTAIN. 
Impacts in The Geysers. At present, staff has concentrated on the geothermal steam resource area, but the need is recognized for future study to include the hot water resource area.

\section{BACKGROUND}

The Geysers-Calistoga KGRA (Figure 2) is located approximately 80 miles north of San Francisco in the north central California Coast Ranges. The 586 square mile KGRA has been characterized as a "scenic region of mountains, steep canyons, hilly uplands, terraced valleys, and flat lake-basins terrain" (SRI, 1978). The area is unique in that it contains subsurface geothermal resources that can be used for electrical power generation and other energy applications.

Geothermal electrical production is currently limited to a small region in the KGRA underlain by geothermal steam (Figure 3,4). In 1.960, the Pacific Gas and Electric Company began generating $11 \mathrm{MW}$ of power using this resource. PGandE's current geothermal electrical generating capacity is $908 \mathrm{MW}$ from 15 generating units. These units are supported by a network of steam wells, s,team pipelines, access roads, and transmission lines. Nine additional power plant proposals made by several utility and geothermal development companies have elther been approved or are being reviewed in the Energy Commission's power plant 11censing process. If constructed, these facilities will increase the electrical generating capacity of the area to 1,669 MW.

The current geothermal steam resource development is occuring over a large area and requires the construction of numerous facllities dispersed over the entire area to obtain the maximum energy production from the resource. This development requires vegetation removal and disturbance of wildlife habitat 


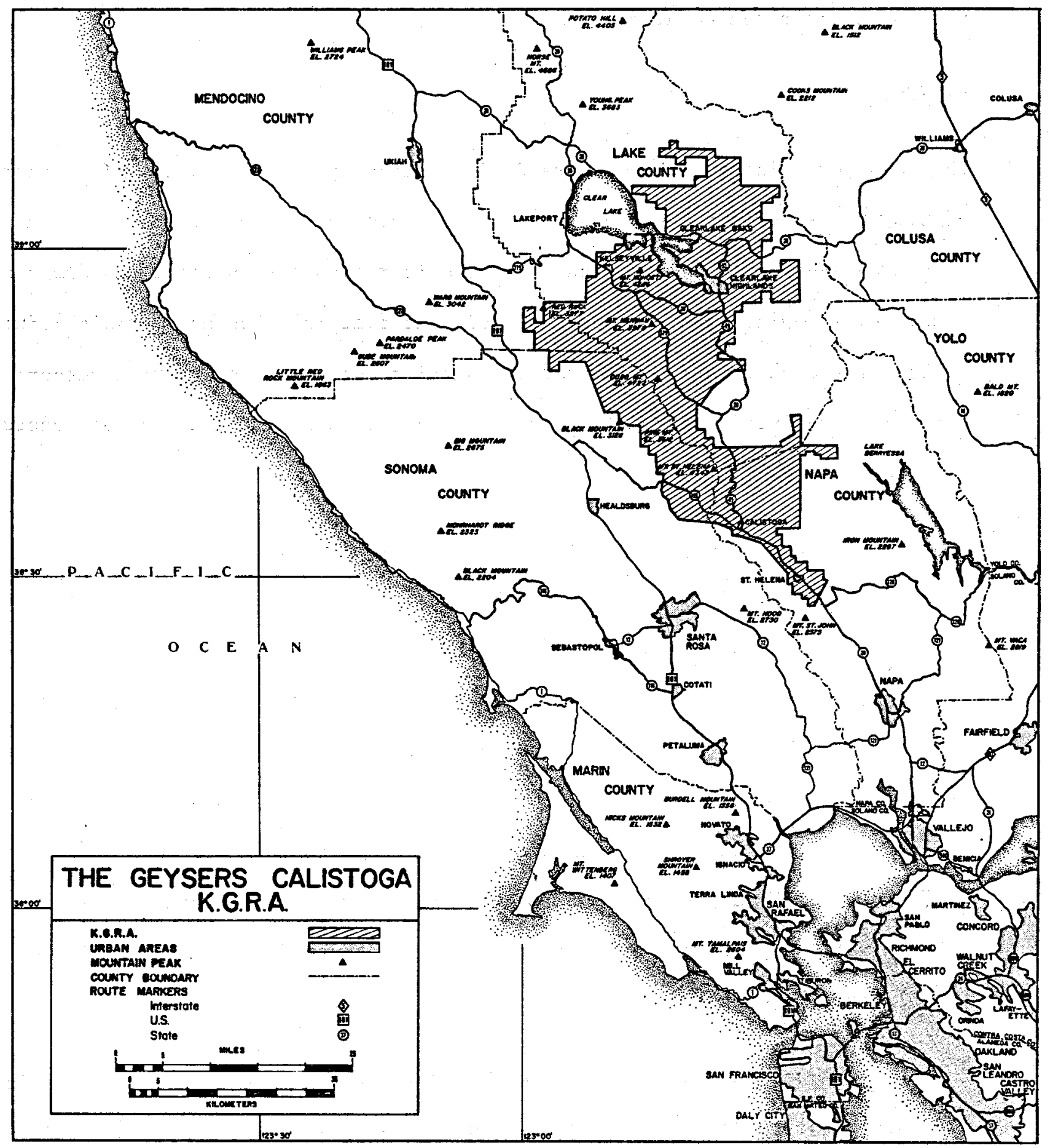

FIGURE 2: KGRA AND SURROUNDING COUNTIES 


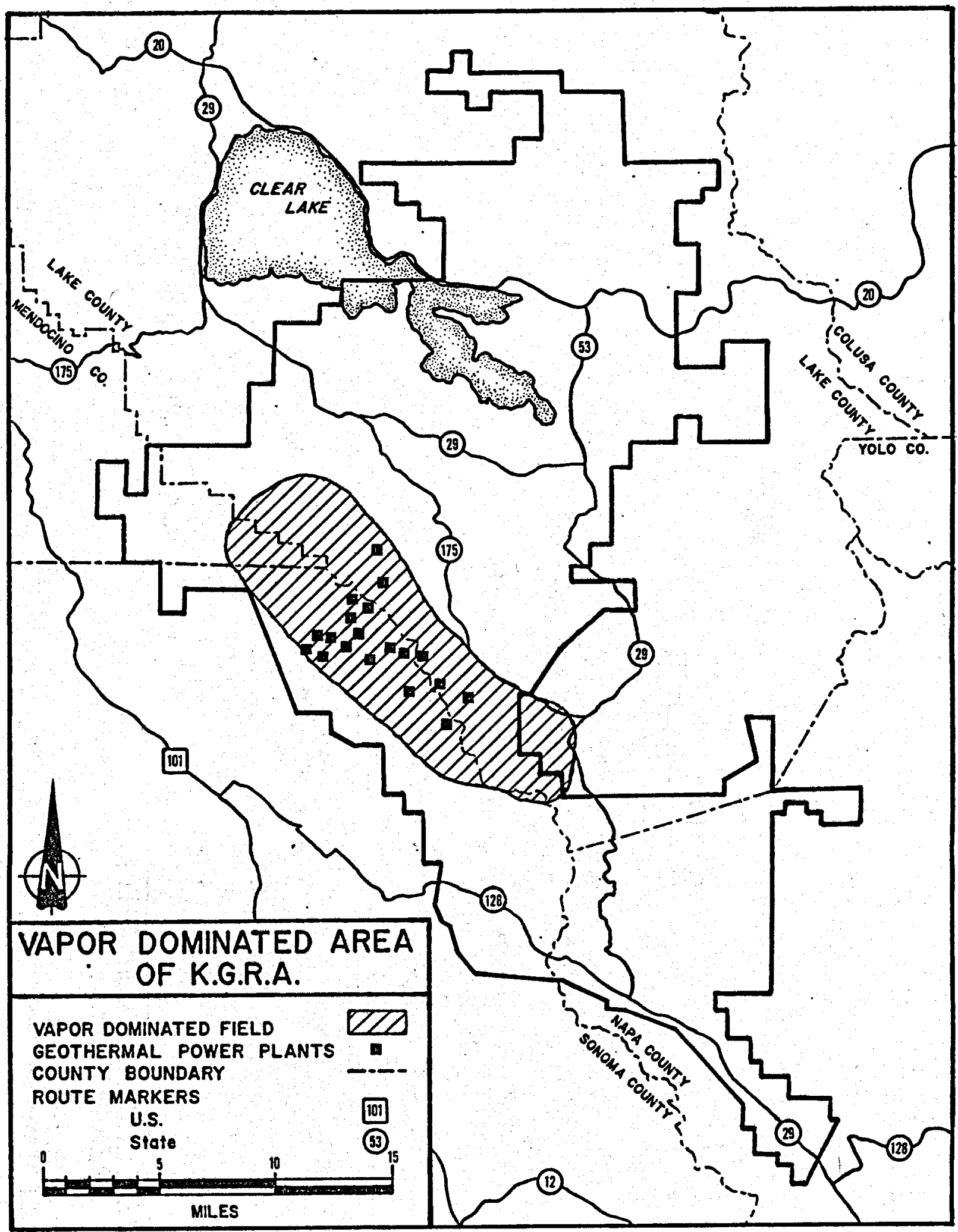

FIGURE 3: DRY STEAM RESOURCE AREA 


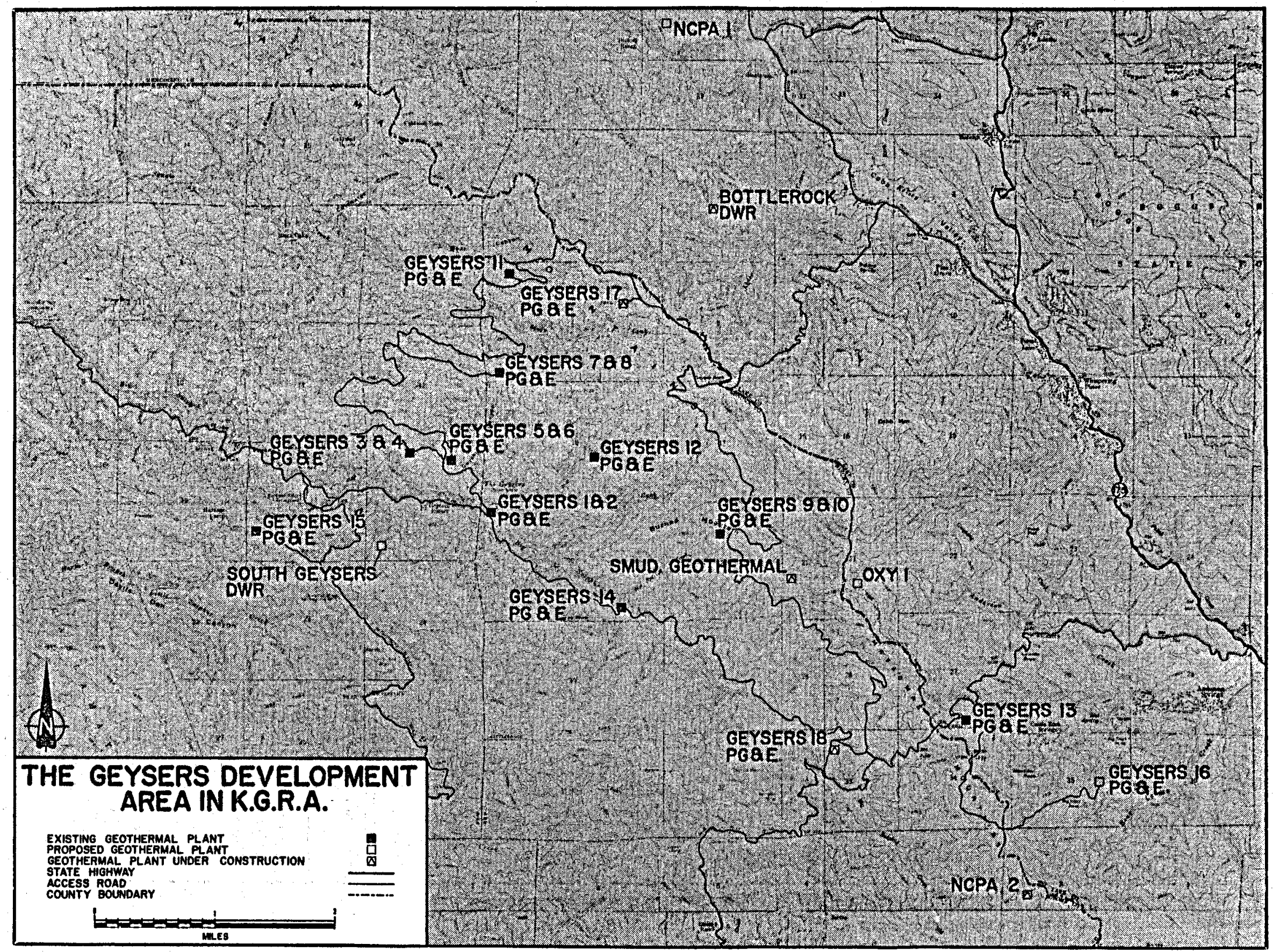

FIGURE 4: THE GEYSERS DEVELOPMENT AREA 
resulting from exploration and construction of the steam wells, steam pipe1ines, roads, power plants, electrical transmission systems, sumps, storage yards, and other facilities.

The blological impacts from inftial geothermal developments were considered on an Individual project basis and not as impacts from regional geothermal - resource development. The significance of each of these individual developments and their impact on biological resources was investigated and reported in various environmental impact documents. Of ten the conclusion reached when each project was considered by itself was that the blological impacts were Insignificant. However, as geothermal development has expanded with an Increasing number of power plants sited in relatively undisturbed areas of high wildife value, cumulative limpacts on biological resources in The Geysers have become an issue. The expanded development is perceived by agencies and public groups concerned with blological resources management as causing a major wildlife habitat loss and associated disturbances in an area that, due to the type of terrain and remoteness, was previously thought as unlikely to be disturbed by an industrial "energy park" type of development. Prior to geothermal development, limited logging and cattle grazing were the only activities that had presented potential conflicts with wildiffe use of the area.

Comments concerning the cumulative effects to blological resources in the Geysers area have been recelved from the California Department of Fish and Game and the United States Fish and Wildilfe Service. According to the California Environmental Quality Act (CEQA, State of California, 1978), "Cumulative Impacts refer to two or more Individual effects which, when considered 
together are considerable or which compound or increase other environmental 1mpacts" (14 Cal. Admin. Code, Section 15023.5). Such impacts should be "...viewed in connection with the effects of past projects, the effects of other current projects, and the effects of probable future projects" (14 Cal. Admin. Code, Section 15082). Letters of comment regarding changes in the area's biological resources have also been recelved from various intervenor groups and area residents. These groups are concerned about geothermal deve1opment which is changing their previously secluded lifestyles.

The flow chart in Figure 1 illustrates the consequences of construction and operation of geothermal power plants and their associated support facllities -(roads, pipelines, transmission lines, well pads, mud sumps, etc.) on blological resources. Due to the interrelationships between components of a biological community, Impacts to one component may ramify throughout the community. Figure 1 reflects this characteristic and represents what are believed to be the most serious cumulative Impacts of geothermal development, by virtue of their potential magnitude for environmental disruption. Both direct vegetation removal for site clearing and indirect impacts from spills and power plant emissions result in an increase in loss and damage to vegetation. These effects on vegetation in turn lead to decreases in wildiffe populations and increases in soil erosion and sedimentation. Increased sedimentation reduces aquatic blological resources. Therefore, an apparent site-specific Impact can combine with other development impacts to result in significant cumulative biological resource impacts. 
OVERVIEW OF GEOTHERMAL RESOURCE

Blological impacts in The Geysers area are associated with the nature of the geothermal resource and the methods required to utilize this resource. This section provides an overview to the area's geology and development methods, so that the nature of the biological Impacts and potential. mitigation can be better understood.

The Geysers region is underlain by intensively deformed and faulted sedimentary, igneous and metamorphic rocks of the Franciscan Formation (GeothermEx, 1980) (Figure 5). The geothermal reservolr rock is formed of fractured, very dense and Impermeable Franciscan graywacke sandstone. Steam flow occurs only when open fractures are intersected by drill holes (Lipman et al., 1977). The reservoir rock is capped by relatively 1mpermeable Franciscan rock types which inhibit descending cold groundwater from entering the reservolr rocks rapidly enough to quench steam formation (CEC, 1979d). The ultimate heat source for the geothermal system is belleved to be a molten magma body, which may cover as much as 100 square miles $\left(240 \mathrm{~km}^{2}\right)$ and 11 e only 13,000 to 16,000 feet $(4-5 \mathrm{~km})$ below the surface (GeothermEx, 1980) (Flgure 6).

Size of the Steam Reservolr-The reservolr system at The Geysers has two portions: a shallow reservolr underlylng an area on the north side of Big Sulphur Creek where surface hydrothermal activity (fumaroles, hot springs) is apparent and a much larger and deeper reglonal reservolr system as shown on Figure 3 (Crow, 1978). Most of the steam produced at The Geysers comes from we1ls that tap the large reservolr system, which extends at least 2.8 miles north and $5.3 \mathrm{mlles}$ southeast of the original wells in the Big Sulphur Creek Canyon area (Crow, 1978). The known fleld is elongated northwest-southeast, appears to be bounded by the Collayom fault on the northeast and the 


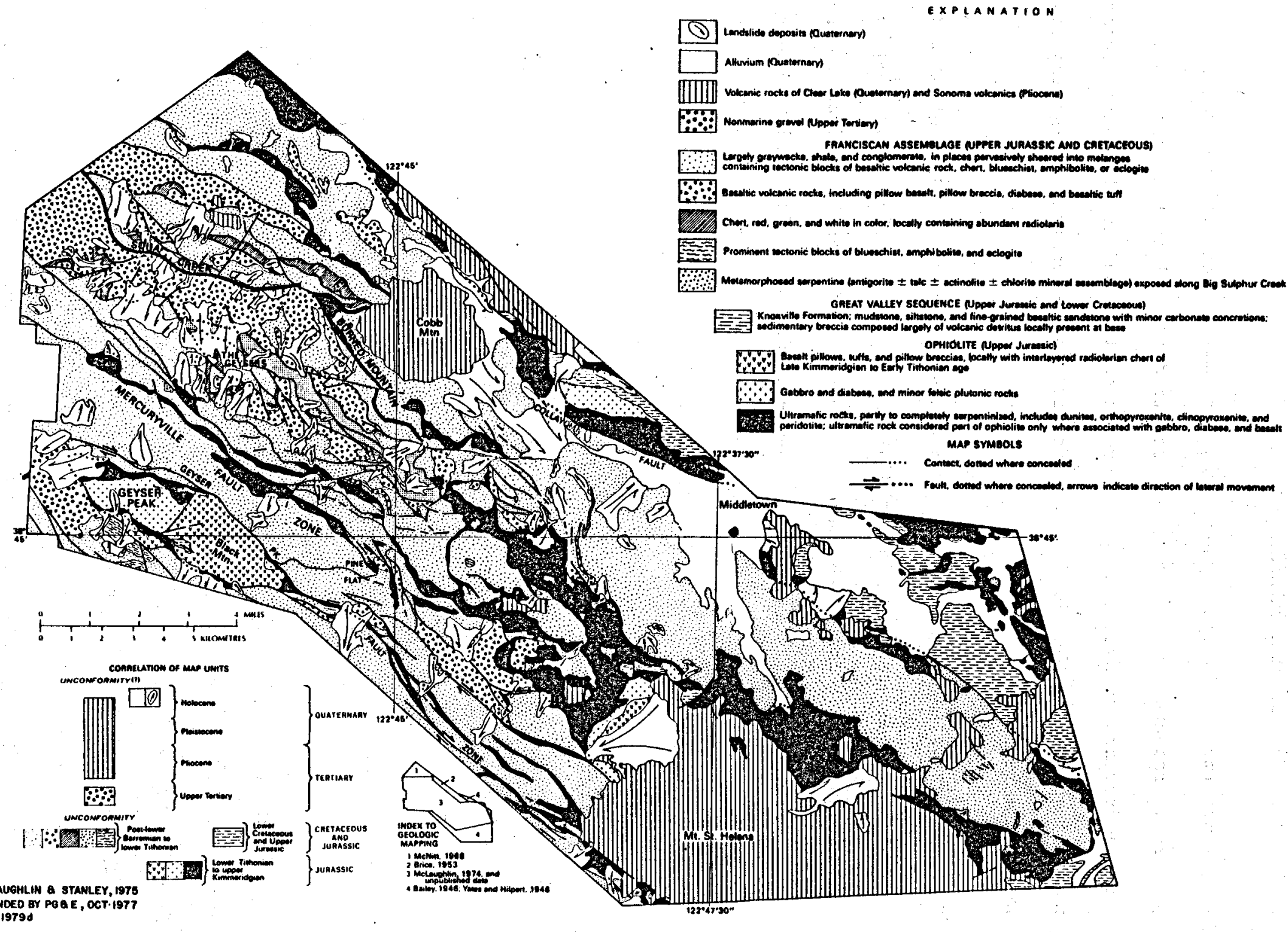
SOUACE I MELAUGHLIN Q STANLEY, 1975
AMENDED BY PGQE, OCT-1977 Fo.

FIGURE 5: GEOLOGICAL MAP OF THE GEYSERS - CLEAR LAKE REGION 


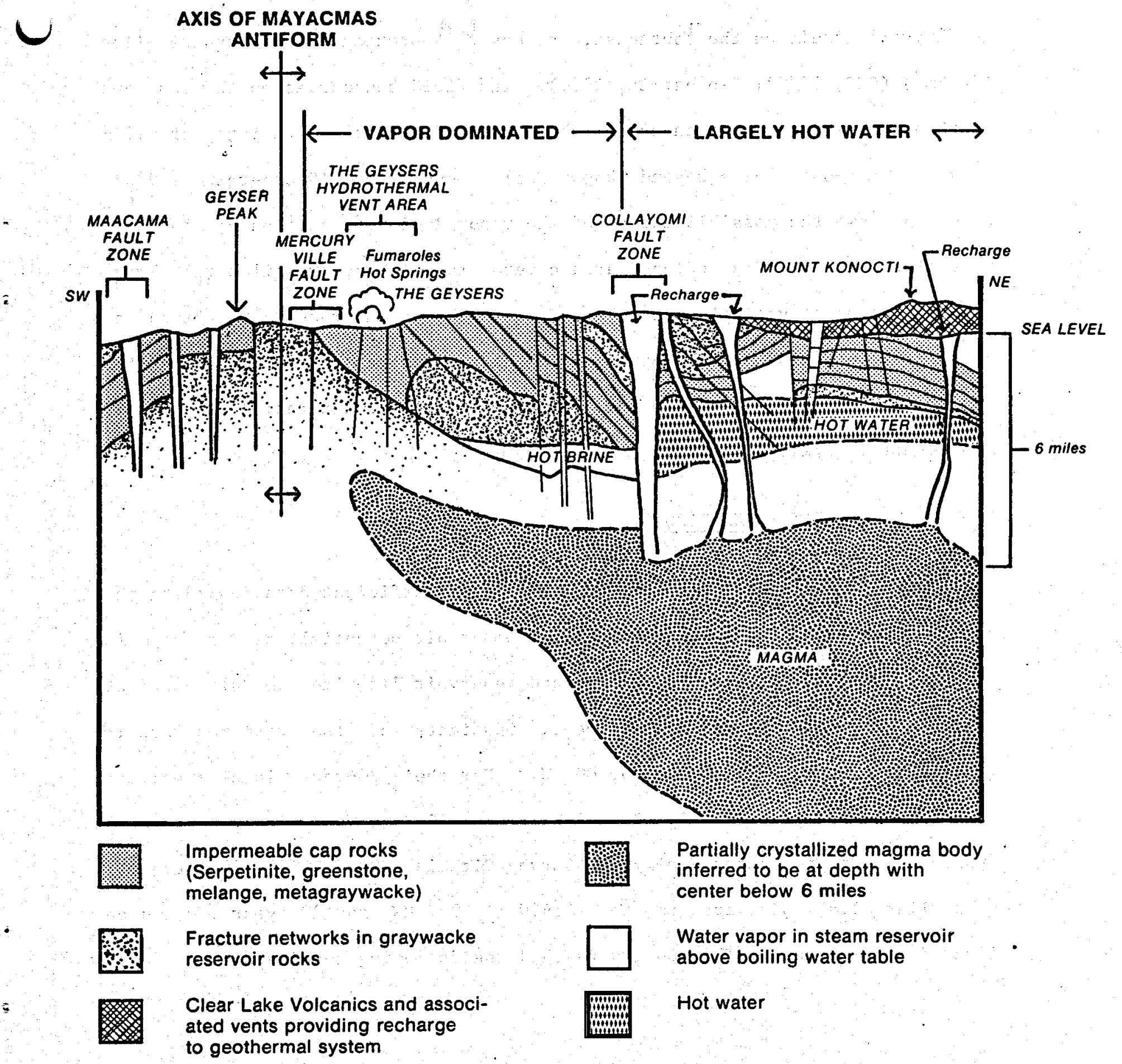

Structural model for the Geysers geothermal system. Cross-section through The Geysers-Clear Lake region, from the Maacama fault zone on the southwest, to Mount Knocti on the northeast, depicting structural elements of The GeysersClear Lake geothermal system.

Source: AAPG, 1979.

FIGURE 6: CROSS-SECTION THROUGH THE GEYSERS -- CLEAR LAKE REGION 
Mercuryville fault on the southeast, and covers approximately 20 square miles $\left(50 \mathrm{~km}^{2}\right.$ ) (CEC, 1979d, GeothermEx, 1980). The field boundaries on the east and southeast have probably been established through success and fallure of wildcats or step-out wells beyond known field boundaries (GeothermEx, 1980). Figure 3 shows the possible extent of the vapor dominated portion of the geothermal resource. The enclosed area covers about 100 square miles $\left(160 \mathrm{~km}^{2}\right)$. However, recent evaluation of the size of the steam reservoir, based on existing information about depth of wells at first steam entry, indicates the portion of the field avallable for practical electrical generation is about 25 square miles (Dykstra, 1981).

\section{GENERATING CAPACITY SCENARIOS}

As the previous discussion indicates, there is insufficient data regarding the nature and size of the steam reservolr. Reservoir potential, as reflected in MW-years (MWy) of extractable energy, and reservoir lifetime are also subject to considerable debate and disagreement. Estimates of the steam resource in The Geysers range from 1,200 to 5,600 MW.* For their 20-year planning period, PGandE assumes approximately 2,000 MW from a 30 square mile area will be available. United States Geological Survey Circular 790 (USGS, 1979) projects

a similar level of development: $1,630 \pm 770 \mathrm{MN}$ for 30 years based on identified resources. The $\mathrm{CEC}$ has reached the following conclusions:

\footnotetext{
*Estimates are calculated as follows: Total steam reserve (MWy) $\div$ power plant amortization period $(30-35 \mathrm{yrs})$, e.g., 70,000 MWy $\div 35$ yrs $=$ 2,000 MN (See Ramey, 1973).
} 
Assume a range of $2,000-3,000 \mathrm{MW}$. . for total electric generating capacity at The Geysers using presently commerclalized technology, 1.e., exploitation of the dry steam resource. Given the conflicting testimony, the fact that much of the exploration data are proprietary and the uncertaintles surround eventual exploitation of other resources (e.g., hot water), it is not possible to state at this time the ultimate generating capacity which will be placed on line at The Geysers or the time frame within which resources will be developed (CEC, 1978b).

For purposes of discussion, three alternative generating capacity scenarios are proposed: High Development Scenario (4,000 MW), Middle Development Scenario $(3,000 \mathrm{MW})$, and Low Development Scenario $(2,000 \mathrm{MW})$ * In each case, geothermal development continues until the scenario generating capacity cefling is achieved. Celling capacity is maintalned as long as steam reserves permit.

Because steam reserves are considered finite and are declining as geothermal development proceeds, the lower the final scenario celling, the longer that level can be sustained.** Generating capacity is assumed to increase at the rate of $200 \mathrm{MW} /$ year, the average rate projected by utilities for the next 10 years (Table 1). If this occurs, the Low Scenarto $(2,000 \mathrm{MH})$, a 220 percent increase over the current level of $908 \mathrm{MW}$, would be reached in 1985, the Middle Scenario (3,000 MW) in 1991, and the High Scenario (4,000 MW) in 1997.

\footnotetext{
*The 4,000 MW figure is basesd on testimony by Ramey (1978), who suggested that steam recovery in other portions of the steam field would be on the same order of magnitude as the 2,000 MW presently assumed to exist. USGS Circular 790 projects $1,630+\mathrm{MW} 770$ and notes that the undiscovered resource base may equal the discovered resource base (CEC, 1979b). Capacity estimates greater than 4,000 MW, e.g., 5,600 MW (SRI, 1978) appear too speculative to consider at this time.

**Under best case assumptions, natural and artificial recharge of the steam reservolr probably does not exceed one-third of steam production. (GeothermEX, 1980). Courts have held that the geothermal steam resource at The Geysers is finite [454f.2d1157 (1972)]. Other discussions of the exhaustible nature of the steam resource 1nclude: GeothermEx, 1980, Isherwood, 1977; Lipman, 1977; Ramey, 1978.
} 
TABLE 1

\section{GEOTHERMAL POWER PLANT DEVELOPMENT IN THE GEYSERS AREA} 1960-1990

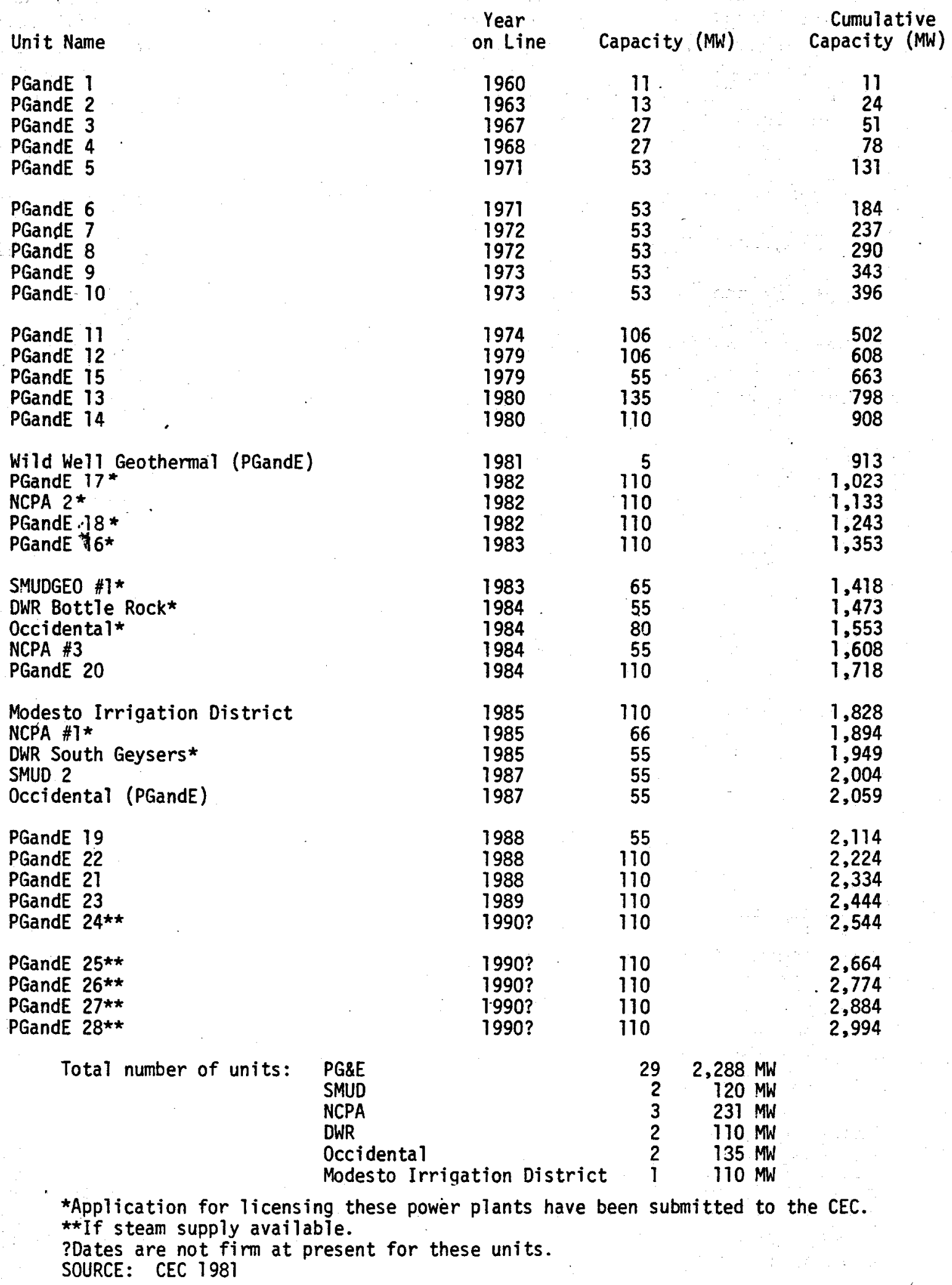


These three energy development scenarios estabish the basic framework around which further discussion of cumulative impacts is developed. Each scenario entails different levels of environmental impacts because each requires different uses of three resources: energy, time and space. The energy represented by the steam resource is recoverable, but the rate and duration of recovery differ for each scenario, as does the surface area or spatial extent of the development process. Cumulative impacts in The Geysers are assessed using the three scenario format. In this way, the potential ranges of such Impacts are bracketed between high and low estimates.

However, while examining these scenarios, it is noted that basic decisions concerning the pattern of energy use for The Geysers geothermal resource have not been established. Presently unanswered questions include: (1) Will the geothermal resource be used for maximum short-term ( 30 - 35 year) energy production? (2) Will it be managed for long-term ( 40 to 100 or more years) production at a lower production rate?

Unless a regional plan of energy production is adopted, the possibility exists that the High Scenario impacts from steamfield development will occur even though the High Scenario electric power production levels are not attained. Economic and other advantages to the steam developers for early establishment of steam flelds and rapid extraction of steam from the resource may lead to the inability of the steam reservoir to support all the electrical generating facilities. This could occur due to uncertainty about the extent and lifetime of the steam resource and the fact that steam resource development precedes by several years the production of electrical power. 
CUMULATIVE VEGETATION IMPACTS

\section{INTRODUCTION}

The KGRA is a $\mathrm{mlx}$ of forest, chaparral, and grassland; location and spectes composition is determined by the interplay of climate, topography, soil type, and other factors (Ornduff, 1976, SRI, 1977). At least 12 vegetation communities exist in the KGRA, each distinguished by the presence of characteristic species (Appendix A). These communities include grassland, oak savannah, oak woodland, chaparral, mixed evergreen forest, yellow pine forest, knobcone pine forest, Douglas fir forest, cypress forest, riparian, aquatic (vegetation growing in or around springs and ponds), and weedy (ruderal).

The development of geothermal power plants and related roads and well fields in The Geysers may have significant cumulative impacts on unique vegetation resources such as riparian, meadow, forest areas, and those occurring on serpentine soils. The abundance, distribution, and mix of these unique vegetatIon resources, areas of critical concern, are an Important aspect of The Geysers blological community. Malntalning the diversity of plant communty assoclations in The Geysers area is necessary to preserve the integrity of the area's blological community as a whole.

RARE AND ENDANGERED PLANTS

Because of the complex arrangement of vegetation, solls, and topography, The Geysers region supports a relatively large number of endemic plant species which are rare or endangered. 
SRI (1977) 1ists over 60 plant species in the KGRA as rare and endangered, the majority of which are herbs found on serpentine outcrops. The SRI inventory Includes plant species found in the entire 586 square mile RGRA, not, just those found in the approximate 100 square mile vapor-dominated portion of the steam field. The completeness of the list is uncertain because field surveys have been primarily restricted to leaseholds within the 20 square mile section of the steam field undergoing geothermal development.

CEC staff has reviewed the California Native Plant Society (CNPS) listing of rare and endangered plants (Smith et al., 1980) and prepared a summary which lists the status of rare plants known or suspected to occur in The Geysers KGRA, Appendix B. This summary separates species which have been identified as rare and endangered (CNPS List 2) from those which are recognized as rare but not endangered (CNPS List 3). Rare and endangered species are those which require a high level of protection in most instances. Species which are rare but not endangered may be indicators of special biological areas and may also require preservation under specific circumstances.

Staff Position--The potential impacts on rare and endangered plants have been raised as a concern by CEC staff in all regulatory cases, both as sitespecific and cumulative impacts. Staff views impacts on rare plants as a serious constraint to the development of geothermal facllities in some areas. Rare plants designated as legally protected on state and federal lists as well as candidate species such as those designated by the California Native Plant Society are given consideration in regulatory cases.

Proposed Solutions--CEC staff recommends that all areas which represent potential habitat for rare plants be identified early in the regulatory process, 
preferably durling the planning stages. Approprlate surveys should be conducted at the project site and in the site vicinity for these species, particularly in areas subject to disturbance by the project. If rare plant specles exist In an area, the area, Including an appropriate surrounding buffer area, should be avolded and/or excluded from development. The spectes involved will dictate the size of this area. It is essential that accurate and complete Information be avallable for the species involved in order to make informed and appropriate decisions. If this information is not avallable, it must be developed through specific fleld research to provide adequate data on a caseby-case basis. Staff recommendations for each case will be developed following a thorough study of the species, the slte, the potential impacts, and all alternatives. Much more fleld work is required in order to determine the number and preclse location of rare and endangered specles found in the KGRA areas most Ifkely to be developed.

\section{DIRECT VEGETATION LOSS}

In the 1iterature, estimates of nonsite-specific vegetation removal ("loss") range from 8 - 20 percent $(51.2$ - 128 acres) for an "average" 640 acre leasehold.* Actual total vegetation loss experienced in The Geysers KGRA is unknown, although slte-specific estimates exist. A 1975 study of habitat loss In the Big Sulphur Creek Watershed estimated 1,024 acres ( 4.0 percent) of a total 25,900 acres had been lost due to the development of $502 \mathrm{MW}$ of geothermal capac1ty. This is the equivalent of 2.04 acres 10 st/MW. A breakdown of acreage losses for each phase of a typical geothermal development is given In Table 2.

\footnotetext{
*8 percent: Suter, 1978; 10-20 percent: SRI, 1977; 20 percent: Reed and Campbe11, 1975, USFWS, 1978.
} 
Table 2

LAND USE REQUIREMENTS FOR A TYPICAL GEOTHERMAL DEVELOPMENT SITE

Phase

Exploration and Testing Phase

Road Construction

Drill Pads

Mud Sump

Ful1 Field Development

Road Construction

Pipelines

Power Generation Facilities

- turbine generators and condensers

-cooling towers

-transformer

Transmission Lines
Surface Area

3 to 4 miles (5.1-6.8 acres)

2.5 acres each, cleared and compacted!

Each one requires an area $100^{\prime} \times 125^{\prime}$ $x 10^{\prime}$ deep to temporarily store up to $1,000,000$ gallons of effluént and cuttings (.29 acres)
Acreage varies. Access roads may be built to drilling pads, mud sumps, building for housing equipment and storage. Average road width is a function of slope, and varies from 15-36 feet 2 I

Each pipeline is $10^{\prime \prime}$ to $30^{\prime \prime}$ in diameter, raised on supports rising no more than 12 feet. The area temporarily cleared for the pipeline is 30 feet wide, but may be wider depending on whether access roads are constructed.2/

Approximately 10.5 acres are required. 3 /

Each is $150^{\prime} \times 65^{\prime \prime} \times 60^{\prime}$ high

Each is $360^{\prime} \times 65^{\prime} \times 60^{\prime}$ high

Each is $100^{\prime} \times 100^{\prime} \times 55^{\prime}$ high

Lines consist of towers or poles at a height of 80 to 120 feet, with concrete bases $40^{\prime}$ apart. Approximately 0.2 acres must be cleared for each tower. Access roads to each tower are required. Existing roads are used where possible.

Notes:

1/ ECOVIEW, 1975a

2) Eaton, 1980

3/ Average of loss estimates for PG\&E Units 16-18; NCPA 1, 2; DWR Bottle Rock, DWR South Geysers; SMUDGEO 1.

Other data from: EPA, 1977; SRI, 1977. 
Published site-specific loss data are avallable only for PGandE UnIts 1 - 6 and 11, unavallable for Units $7-10,12-15$, and estimated for all other units under construction or In the licensing process (Table 3). Using avallable data, losses for these units are estimated to be 54 acres ( 6.3 percent) per average 856 acre leasehold, or 0.55 acres per megawatt of power generatIon. However, M.K. Eaton of PGandE (Eaton, 1981) has estimated vegetation loss for PGandE Unfts 1 - 18 over the 30 year Iffe of these power plants to be 11.5 percent $(1,137$ acres $)$ of the total Unit $1-18$ leasehold area $(9,896$ acres), or $0.93 \mathrm{acres} / \mathrm{MW}$.

Estimated cumulative vegetation losses in The Geysers range widely, from 1,100 acres (Low Scenario of $2,000 \mathrm{MW}, 0.55$ acres/MW) to as high as 7,040 acres (High Scenarlo, of 4,000 MW, 1.76 acres/MW) (Figure 7, Table 4). If the 11.5 percent estimate is assumed to accurately reflect existing and future vegetation loss, there would be a loss of 2,790 acres for the Middle scenario of 3,000 MW; cumulative losses could range from 1,860 (Low Scenario) to 3,720 acres (High Scenario).

Several cautionary notes are, necessary with respect to acreage loss figures (Table 3). Even if PGandE estlmates are accepted as the best avallable, they are probably low, due to the nature of the estimating process. Losses for Units 1 - 6 and 11 were calculated by planimetry from aerial photographs; a technique which underestimates surface area on slopes. Secondly, acreage losses are given on a per leasehold basis, which is somewhat misleading because disturbances such as access roads, portions of steam pipelines, transmission line clearing and access roads, and construction and storage yards may occur outslde of leasehold boundaries. 
Table 3

ESTIMATED VEGETATION LOSS

\begin{tabular}{|c|c|c|c|c|c|}
\hline Power Plant & Megawatts & $\begin{array}{c}\text { Total } \\
\text { Leasehold } \\
\text { Area (Acres) }\end{array}$ & $\begin{array}{c}\text { Area of } \\
\text { Vegetation } \\
\text { Lost (Acres) }\end{array}$ & $\begin{array}{c}\text { Percent } \\
\text { of } \\
\text { Leasehold }\end{array}$ & $\begin{array}{c}\text { Acres } \\
\text { Lost } \\
\text { Per Megawatt }\end{array}$ \\
\hline
\end{tabular}

PG\&E UNITS

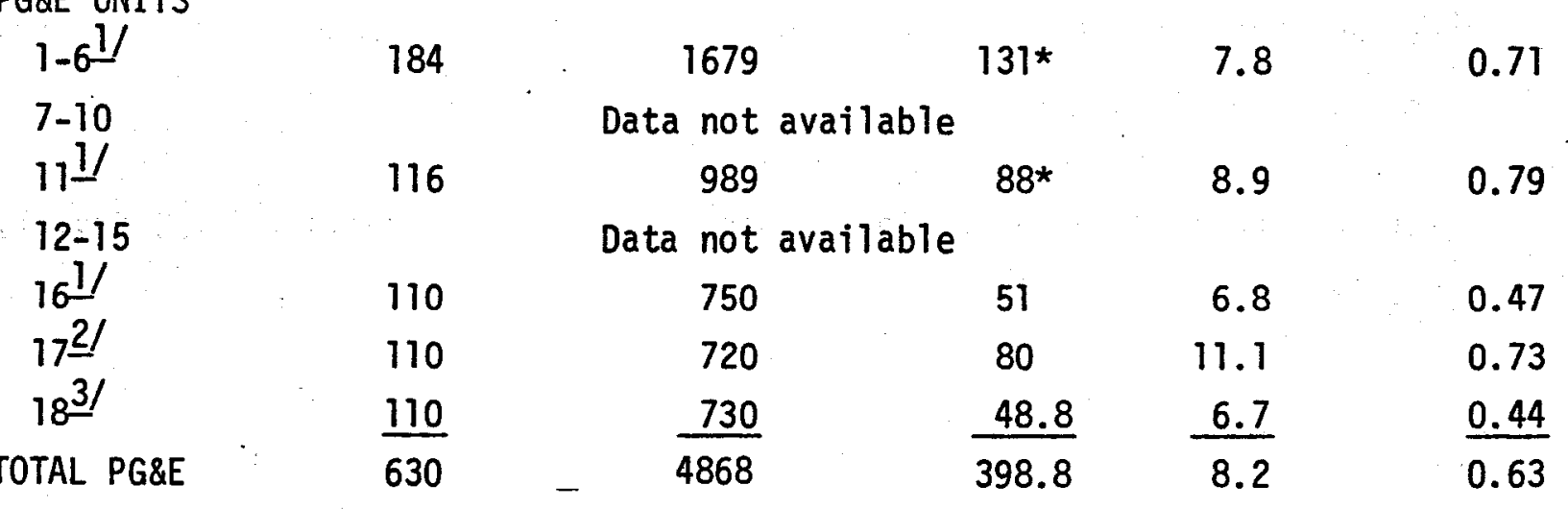

CALIFORNIA DEPARTMENT OF WATER RESOURCES 4 /

$\begin{array}{lccccc}\text { Bottle Rock } & 55 & 370 & 30 & 8.1 & 0.54 \\ \text { South Geysers } & 55 & \frac{408}{778} & \frac{30}{60} 5 & \frac{7.4}{7.7} & \frac{0.54}{0.54}\end{array}$

NORTHERN CALIFORNIA POWER AGENCY

$\begin{array}{lrrrrr}\text { NCPA } 1 & 66 & 1400 & 11 & 0.8 & 0.17 \\ \text { NCFA } 2 & \frac{110}{176} & \frac{1120}{2520} & \frac{47}{58} & \frac{4.2}{2.3} & \frac{0.43}{0.33}\end{array}$

SACRAMENTO MUNICIPAL UTILITY DISTRICT

$\begin{array}{llllll}\text { SMUDGEO } 1 & 55 & 396 & 22 & 5.6 & 0.40\end{array}$

TOTAL (PG\&E, CDWR,

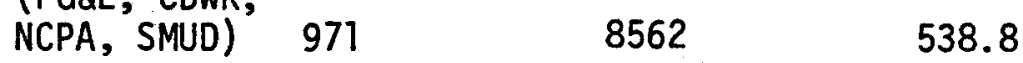

AVERAGE (PE'

LEASEHOLD)

$97.1 \quad 856$

54

6.3

0.55

*Actual losses (Weinberg, 1978)

Source: 1/ Weinberg, 1978; 2/ CEC, 1979c; 3/ CEC 1979d; 4/CDWR, 1978, 1979; 5/ NCPA, 1978, 1979; 6/ SMUD, 1980. 
ACRES OF

VEGETATION

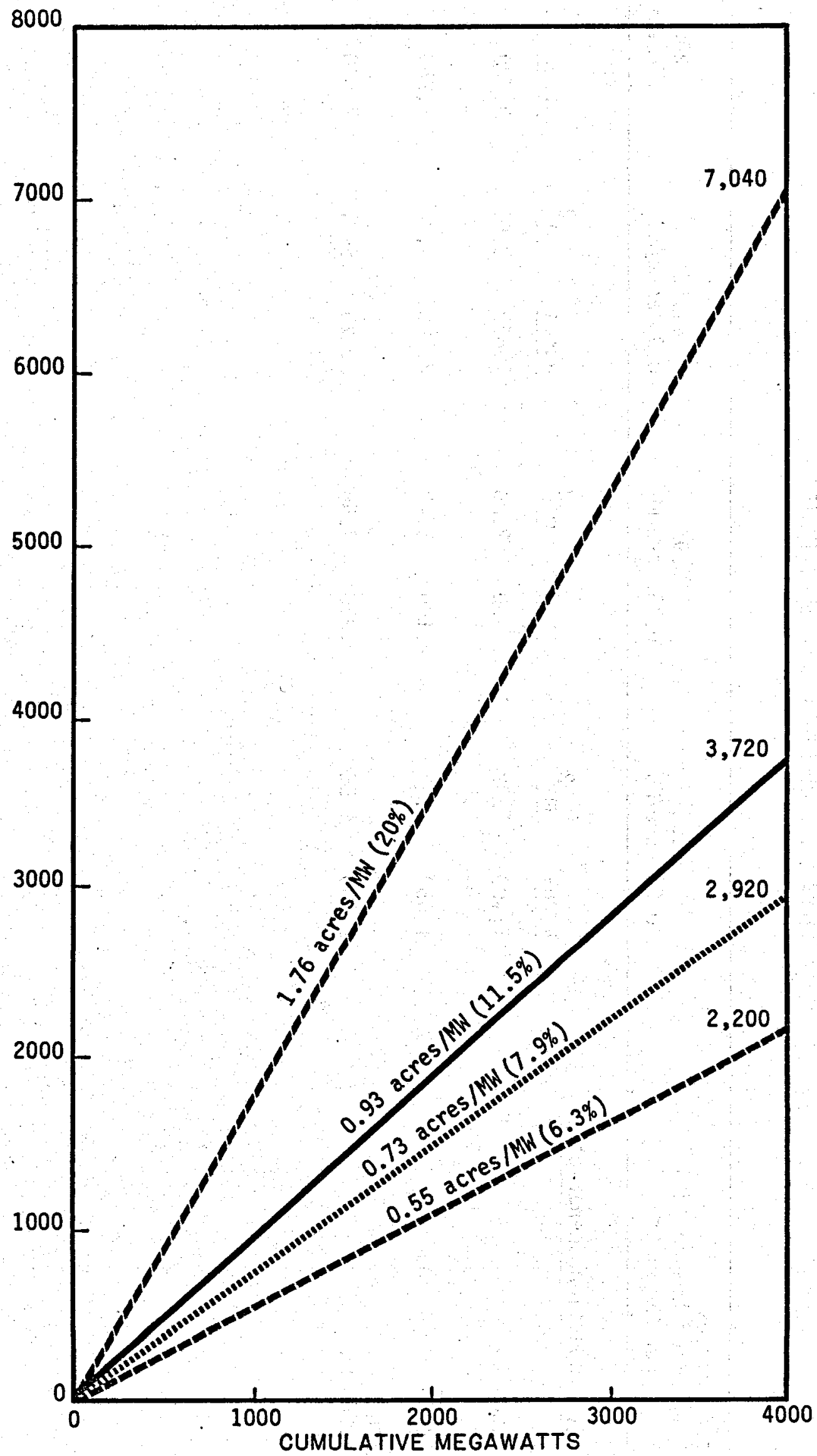

FIGURE 7: ACRES OF VEGETATION LOSS PER CUMULATIVE MEGAWATT OF POWER GENERATED 
Table 4

CUMULATIVE VEGETATION LOSS ESTIMATES

\begin{tabular}{|c|c|c|c|c|c|c|c|c|}
\hline \multirow[t]{2}{*}{$\begin{array}{l}\text { Loss Scenarios } \\
\text { Percent of Leasehol } \\
\text { Area per Megawatt }\end{array}$} & \multicolumn{2}{|c|}{$\begin{array}{c}6.3 \% \\
0.55 \text { acre/MW } \\
\end{array}$} & \multicolumn{2}{|c|}{$\begin{array}{c}7.9 \% \\
0.73 \mathrm{acre} / \mathrm{MW}\end{array}$} & \multicolumn{2}{|c|}{$\begin{array}{c}11.5 \% \\
0.93 \mathrm{acre} / \mathrm{MW}\end{array}$} & \multicolumn{2}{|c|}{$\begin{array}{l}20 \% \\
1.76 \mathrm{acre} / \mathrm{MW}\end{array}$} \\
\hline & acres & $\underline{m i}^{2}$ & acres & $\underline{m i}^{2}$ & acres & $\mathrm{mi}^{2}$ & acres & $\underline{\mathrm{mi}}^{2}$ \\
\hline $\begin{array}{l}\text { LOW } \\
2,000 \mathrm{MW}\end{array}$ & 1,100 & 1.72 & 1,460 & 2.28 & 1,860 & 2.91 & 3,520 & 5.5 \\
\hline $\begin{array}{l}\text { MIDDLE } \\
3,000 \mathrm{MW}\end{array}$ & 1,650 & 2.58 & 2,190 & 3.42 & 2,790 & 4.36 & 5,280 & 8.25 \\
\hline $\begin{array}{l}\text { HIGH } \\
4,000 \mathrm{MW}\end{array}$ & 2,200 & 4.56 & 2,920 & 4.56 & 3,720 & 5.81 & 7,040 & 11.0 \\
\hline
\end{tabular}


Although it is technically correct to estimate per leasehold vegetation loss, In doing so one loses sight of the truly widespread nature of development in this region. Vegetation loss per leasehold can be estimated without noting that leaseholds are increasingly interconnected by roads, pipelines (e.g., Angwin and Toy, 1979, p. 5 - 11) and transmission lines. Percentage losses can also be estimated without noting that leaseholds are of different sizes.

Staff Position-The amount and type of vegetation loss has been ralsed by CEC staff, CDFG, and Intervenors as a potential issue in all Geysers regulatory cases. Concerns have been voiced over both site-specific and cumulative losses of unique vegetation resources. Only the vegetation losses directly - associated with power plant sites have been prevented or mitigated, while losses assoclated with well fleld and road development have not been dealt with. This potential cumulative loss, which could be as high as 5,280 acres ( 1.76 acres/MW), as well as the loss of unique vegetation resources, would be significant.

The CEC staff position has been to avold development on areas of unique vegetation and to reduce vegetation disturbance and removal to a minimum. At present, sufficient detalled information about the location and abundance of unique vegetation resources and the disturbance of other vegetation communities within the geothermal resource area is not avallable. Without this detalled Information, an effective assessment cannot be made of the cumulative impacts from projected geothermal development or about the effectiveness of sitespeciflc mitigation measures applied to date.

Proposed Solutions--In order to prevent or mltigate potential cumulative Impacts due to loss of unique vegetation In The Geysers and to evaluate and improve present mitigation measures, the following recommendations are made: 
1. Develop Geysers resource maps showing detailed plant associations and the location and distribution of unique vegetation resources. These documents should be used by the Commission, counties, other permitting agencies, resource developers, and the utilities in planning, permitting, and monitoring geothermal development in The Geysers steam area.

2. Avoid or limit disturbance of unique vegetation resource areas (i.e., serpentine barrens, hot springs, fumaroles, meadows, seeps, forest, and riparian associations, etc.).

3. Require reestablishment of native vegetation on all nonuse areas which have been disturbed ( $1 . e .$, cut and fill slopes).

\section{INDIRECT IMPACTS TO VEGETATION}

Indirect effects to vegetation may result from several sources including exposure to toxic materials contained in cooling tower drift, exposure to hydrogen sulfide $\left(\mathrm{H}_{2} \mathrm{~S}\right)$, acid rain, climate modification, and mechanical damage. Each of these potential impact sources is discussed below.

Cooling Tower Drift--Vegetation stress in the vicinity of power plants at The Geysers was first noted in 1971 and first publicly reported for vegetation near PGandE Units $1-6$ in 1973. Since that time a considerable amount of Information has been developed to determine the cause and rates of vegetation stress. The most complete information available is presented in Malloch et al., 1979, from which much of the following discussion is drawn.

Early Investigators were somewhat uncertain as to the causes of foliar stress, but deposition of salts, particularly boron, carried in mists from the cooling towers was suggested (ECOVIEW, 1975b). Qualitative observations during August - December 1978 and in 1979 have verified earlier reports of marginal 
necrosis (tissue death along the leaf margin), interveinal necrosis, interveinal chlorosis (yellowing of tissue between leaf veins due to loss of chlorphy11) and needle t1p burn and banding (conffers) for 22 species of trees and shrubs (Table 5). In general, moderate to severe vegetation damage over varying acreages has occurred around PGandE power plant Units 1 - 11.*

Follar stress symptoms such as necrosis and chlorosis are indicative of boron toxicity. Leaf tissue analyses show greatly elevated boron concentrations in visibly damaged versus visibly undamaged samples. Vegetation grown in solls high in boron concentration near power plants develops boron toxicity symptoms. Similarly, plants exposed to cooling tower drift develop toxic symptoms. Additional support for the hypothesis that boron deposition causes follar stress comes from two Canadian studies on the phytotoxicity of airborne boron (Temple and Linzon, 1976, Temple et al.; 1978). Deposition of boron on vegetation exposed to atmospheric boron emissions from a fiberglass manufacturing plant produced injury symptoms on sensitive species. As in The Geysers, the amount and severity of follar infury decreased with increasing distance from the source.

Cumulative stress and vegetation damage from cooling tower drift has been documented by PGandE as part of a six year (1973-1978) aerial photography study.** The 38.6 square mile study area 11es within the Big Sulphur Creek and Kelsey Creek watersheds and encompasses the developed portion of The Geysers KGRA. The total extent of stressed vegetation in this area as of 1979 covers 247 acres (6 percent) of the total leasehold area of PGandE Units $1-11$

\footnotetext{
*Data for Units 12 and 15 were unavallable for Inclusion in Malloch's 1979 report.

**The drought of 1975-1976, 1976-1977 could have contributed to observed vegetation stress.
} 
Table 5

VEGETATICN DAMAGED BY COOLING TOHER DRIFT

\begin{tabular}{|c|c|c|}
\hline Power Plant & Vegetation Damaged & Degree of Damage \\
\hline PG\&E 1,2 & $\begin{array}{l}\text { Big leaf maple (Acer macroohyllum) } \\
\text { Brutia pine (Pinus brutia) } \\
\text { California bay (Umbellularia californica) } \\
\text { Digger pine (Pinus sabiniana) } \\
\text { Eucalyptus (Eucalvotus sp.) } \\
\text { Interior live oak (Quercus Wislizenii) } \\
\text { Valley oak (Quercus Iobata) }\end{array}$ & $\begin{array}{l}\text { Severe } \\
\text { Severe } \\
\text { Severe } \\
\text { Moderate } \\
\text { Moderate } \\
\text { Moderate } \\
\text { Sevére }\end{array}$ \\
\hline PGeE 3,4 & $\begin{array}{l}\text { Big leaf maple (Acer macrochillum) } \\
\text { California bay (Umbellularia californica) } \\
\text { Digger pine (Pinus sakiniana) } \\
\text { Elderberry (Sambucus mexicana) } \\
\text { Fig (Ficus carica) } \\
\text { Interior live oak (Quercus wislizenii) } \\
\text { Madrone (Arbutus menziesii) } \\
\text { Spicebush (Calycanthus occidentalis) } \\
\text { Valley oak (Quercus lobata) }\end{array}$ & $\begin{array}{l}\text { Severe } \\
\text { Severe } \\
\text { Moderate } \\
\text { Moderate } \\
\text { Moderate } \\
\text { Moderate } \\
\text { Moderate } \\
\text { Moderate } \\
\text { Severe }\end{array}$ \\
\hline PGSE 5,6 & $\begin{array}{l}\text { Big leaf maple (Acer macronhyllum) } \\
\text { California bav (Jmbellularia califomica) } \\
\text { Digger pine (Pinus sabiniana) } \\
\text { Douglas fir (Pseudotsuga menziesii) } \\
\text { Interior live oak (Quercus Wislizenii) } \\
\text { Madrone (Arbutus menziesii) } \\
\text { Spiceish (Calycanthus occidentalis) } \\
\text { Valley Oak (Quercus lobata) }\end{array}$ & $\begin{array}{l}\text { Severe } \\
\text { Severe } \\
\text { Moderate } \\
\text { Severe } \\
\text { Moderate } \\
\text { Moderate } \\
\text { Moderate } \\
\text { Severe }\end{array}$ \\
\hline PGSE 7,8 & $\begin{array}{l}\text { California bay (Umbellurania califemica) } \\
\text { California nutmeg (Torreva caliomica) }\end{array}$ & $\begin{array}{l}\text { Severe } \\
\text { Severe }\end{array}$ \\
\hline
\end{tabular}


Table 5 - Continued

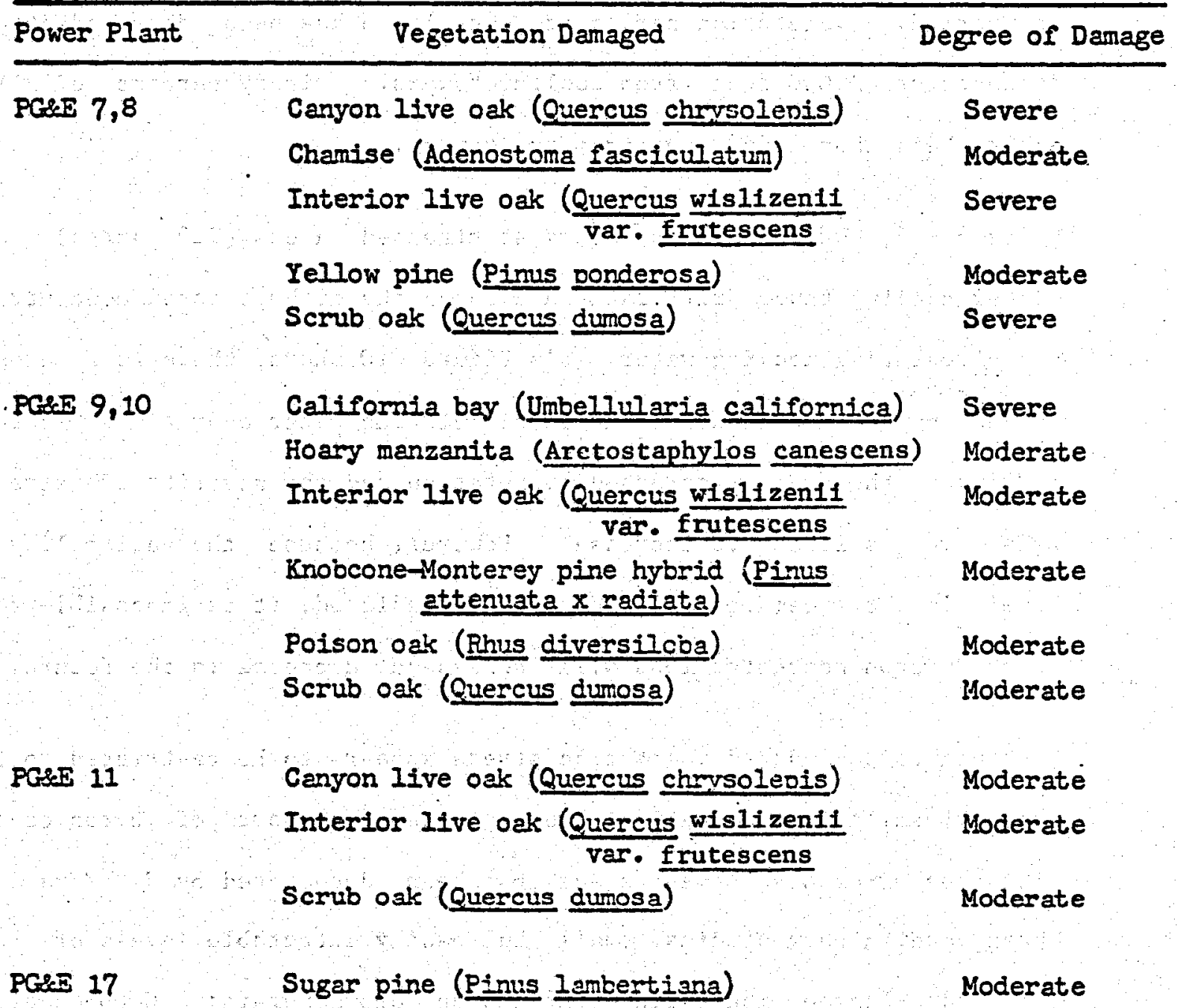

SOURCE: Malloch et al., 1979. 
(Table 6). Diagrams based on aerial photographs clearly show the incremental nature of vegetation stress (FIgure 8,9). All units except 1 and 2 and 9 and 10 have shown increases in area of stressed vegetation over the six year survey period. Vegetation stress at Units $1-6$ has been detected at a maximum distance of 2,000 feet from cooling towers. Ninety percent of all damage occurs less than 1,640 feet from the towers.

Units $3-6$, which have the largest stressed areas ( 210 acres), also have higher cooling tower drift rates and among the highest boron concentrations in the circulating cooling water. As Figure 10 shows, there is a trend toward increasing boron concentrations in circulating water over time. If this trend continues, the area of stressed vegetation and the severity of stress within this area is likely to increase. However, because the variability of boron levels in the steam reservoir cannot be predicted, it is impossible to predict whether boron concentrations will increase or decrease in the future.

Although boron-induced vegetation stress appears to be restricted to the immediate vicinity of operating power plants, transport of boron considerable distances from development areas has been documented by J. Koranda (1980). During preliminary studies, small but easily detectable levels of boron were recorded at three monitoring stations on Cobb Mountain: Cobb Mountain near Geysers Rock, 27 ppm; Sawml11 Flats Road (0.4 miles from Bottle Rock Road), 14 ppm; and Sawmill Flats Road ( 1.4 miles from Bottle Rock Road), 15 ppm. The two measurements on Sawmill Flats Road on the north side of Cobb Mountain suggest that some drift or well-site effluents are moving over Cobb Mountain into the adjacent airshed to the east. These Boron concentrations observed by Koranda are one and two orders of magnitude smaller than those found in damaged vegetation near power plants (cf. Malloch et al., 1979, Table 12, 13, 14). 
Table 6

ANNUAL EXTENT OF STRESSED VEGETATION AROUND PGEE UNITS 1-11

DURIIIG 1973-1978 (ACRES)

\begin{tabular}{|c|c|c|c|c|c|c|c|}
\hline Year & 1 and 2 & 3 and 4,5 and 6 & $\frac{\text { Unit }}{7 \text { and } 8}$ & 9 and 10 & 11 & Total & $\begin{array}{l}\text { Annial } \\
\text { Change } \\
(\%)\end{array}$ \\
\hline $1973^{\circ}$ & 10 & 133 & 7 & * & * & 150 & \\
\hline 1974 & 10 & 133 & 7 & 5 & * & 155 & 3 \\
\hline 1975. & 10 & 185 & 7 & 5 & $5 * *$ & 212 & 27 \\
\hline 1975 & & No Photo & ge - & - & & & \\
\hline 1977 & 10 & 210 & 10 & 5 & 10 & 245 & 7.5 \\
\hline 1978 & 10 & 210 & 12 & 5 & 10. & 247 & 8 \\
\hline
\end{tabular}

- Units Not Operational

**Unit began operation in May 1975, film survey flown in August 1975.

SOURCE: Malloch et al., 1979. 


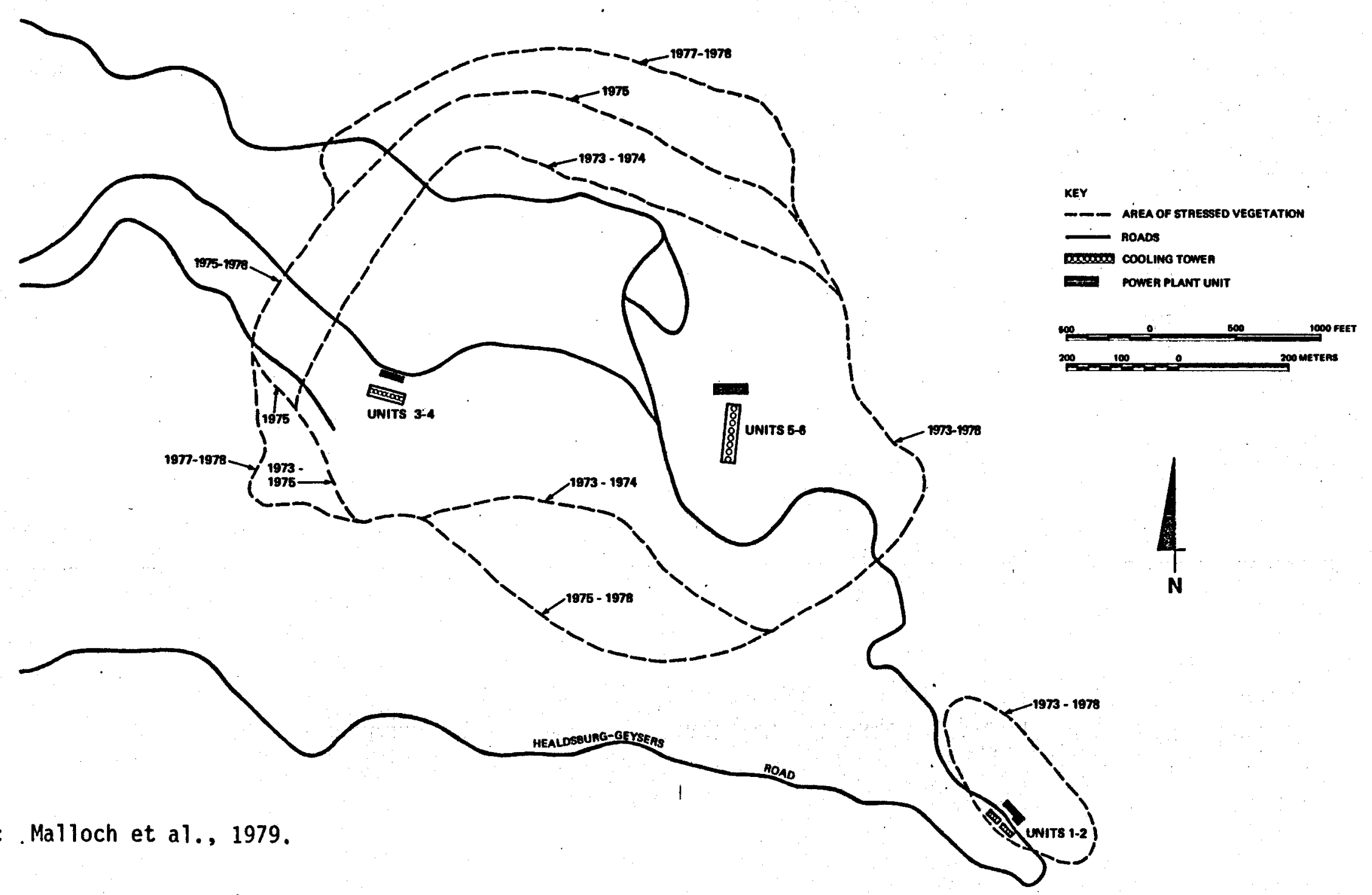

FIGURE 8: THE AREA OF STRESSED VEGETATION AROUND GEYSERS UNITS 1-6 IN 1973-1978 

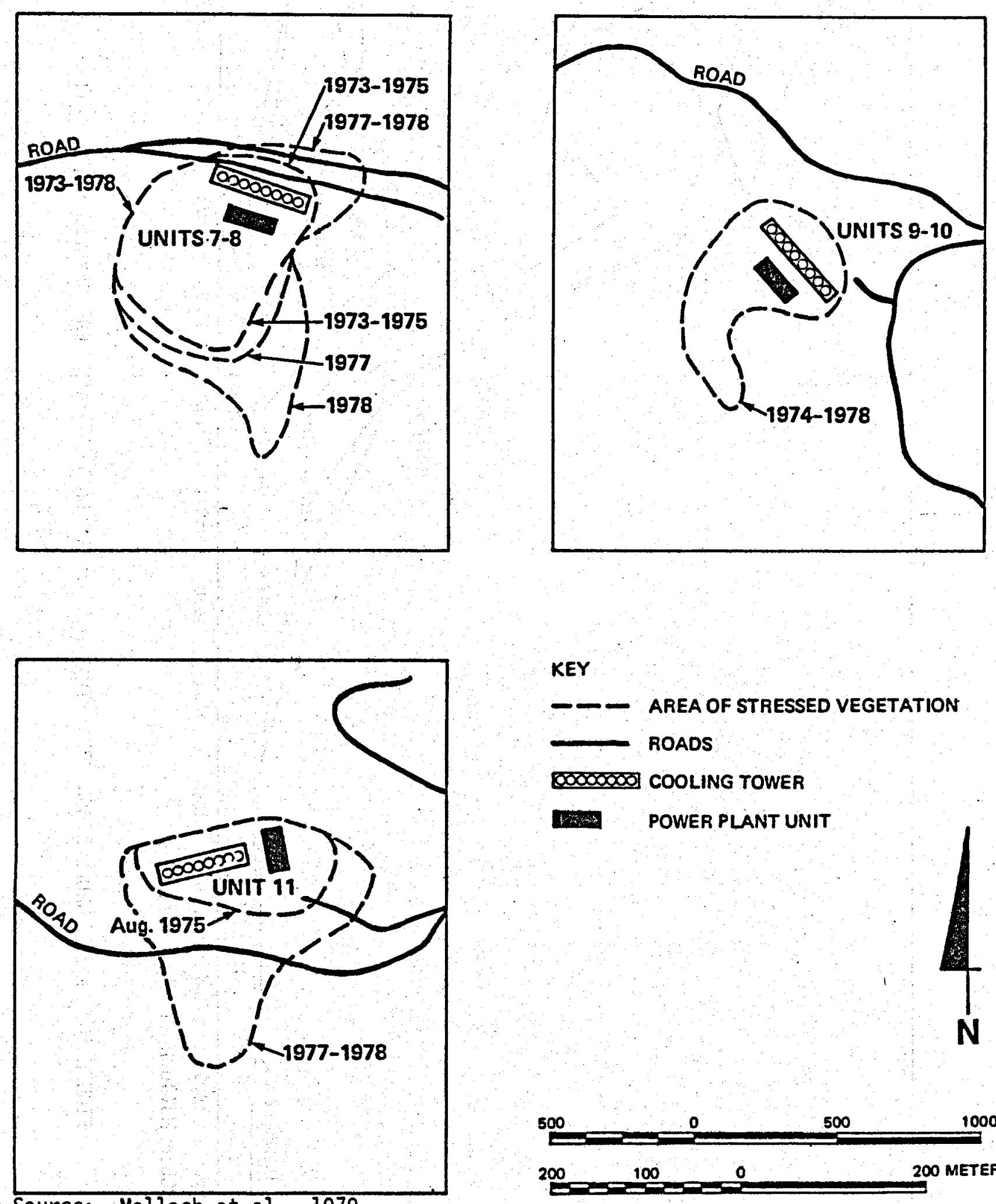

\section{COOLING TOWER}

Fis POWER PLANT UNIT

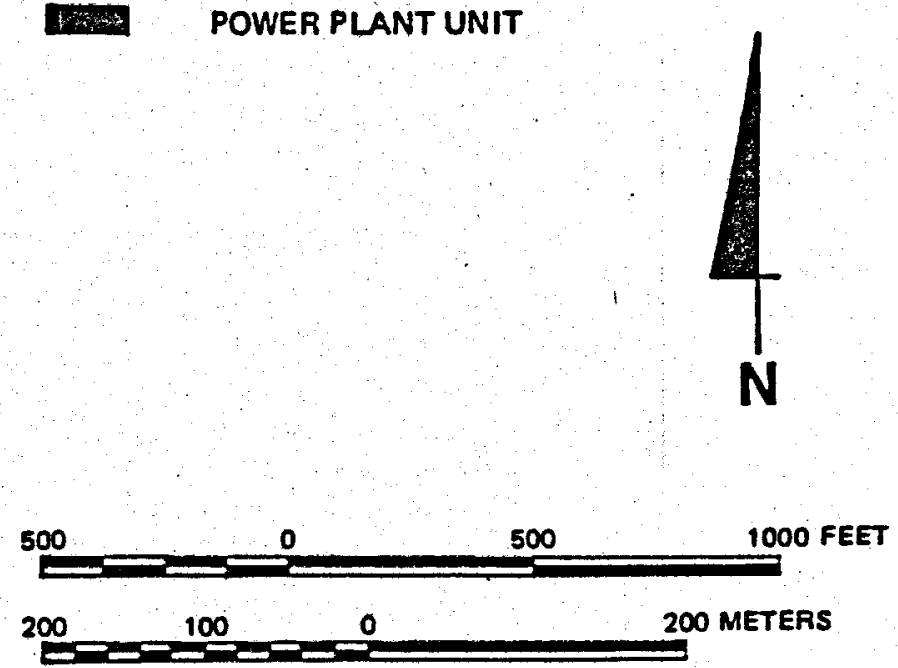

FIGURE 9: THE AREA OF STRESSED VEGETATION AROUND GEYSERS UNITS 7-11 IN 1973-1978 


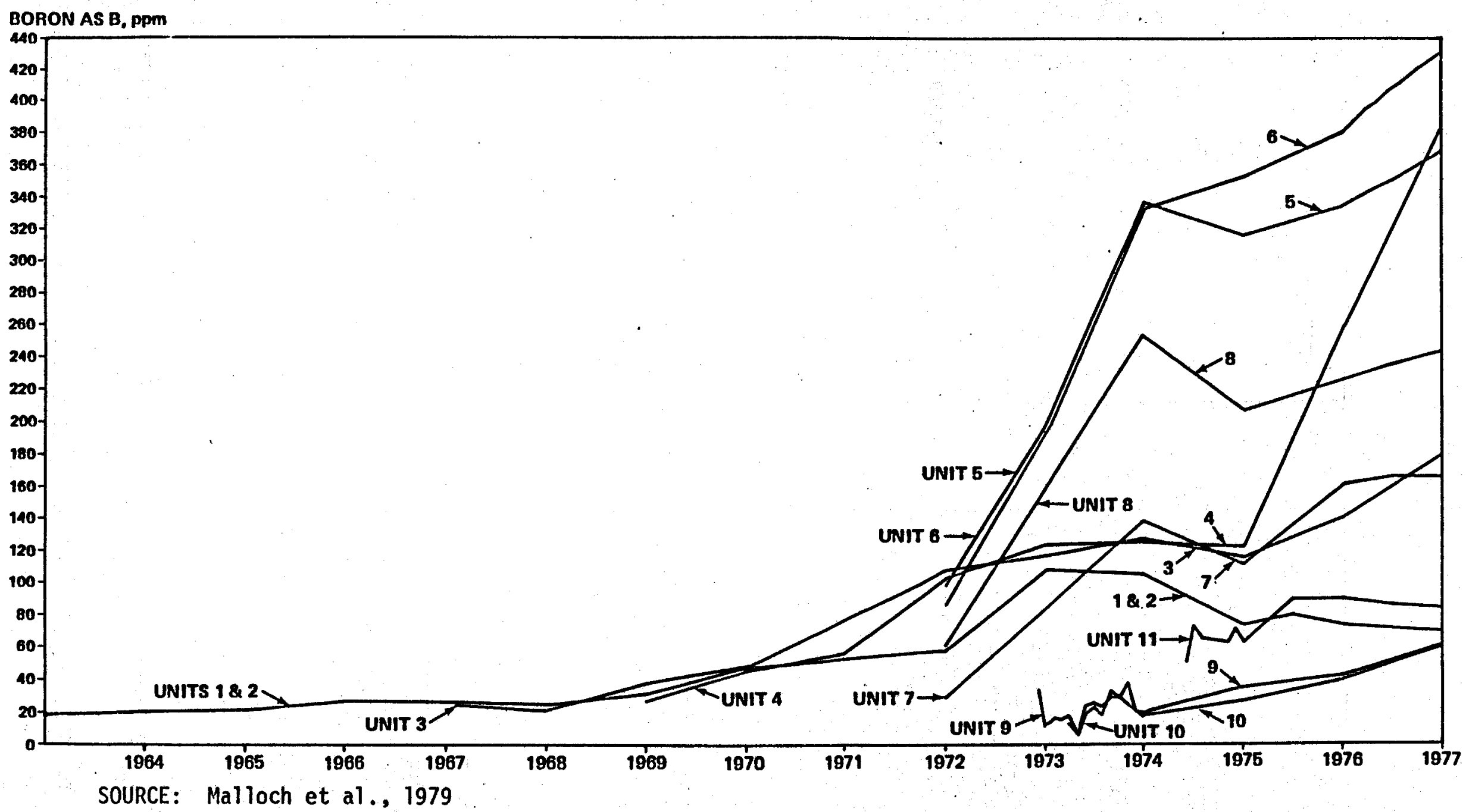

FIGURE 10. MEAN ANNUAL BORON CONCENTRATIONS IN CIRCULATING WATER FOR GEYSERS UNITS 1-17 
Eydrogen Sulfide Emissions--In light of the present data, and relative to other blological resource concerns at The Geysers, the effects of $\mathrm{H}_{2} \mathrm{~S}$ on vegetation cannot be considered important. Thompson (1978) states that it is unclear "whether the present atmospheric level of $\mathrm{H}_{2} \mathrm{~S}$ or its reaction products is causing environmental injury to local vegetation."* He does state that the rate at which $\mathrm{H}_{2} \mathrm{~S}$ is oxidized to sulfur dioxide $\left(\mathrm{SO}_{2}\right)$, a much more phytotoxic gas than $\mathrm{H}_{2} \mathrm{~S}$, is 67 percent faster than previously believed (half-1ife $\mathrm{H}_{2} \mathrm{~S}=$ 12 hrs). This allows less opportunity for atmospheric dilution and dispersion, thereby increasing the risk of vegetation damage.

Long-term exposure $\left(8-10\right.$ weeks) of native vegetation to $\mathrm{H}_{2} \mathrm{~S}$ at concentrations in the $0.1-3.0 \mathrm{ppm}$ range has been reported by Thompson and Kats (1978) to have damaged yellow pine (Pinus ponderosa), California buckeye (Aesculus californica), and Douglas fir (Pseudotsuga menziesil). The same range of $\mathrm{H}_{2} \mathrm{~S}$ concentrations has been observed at The Geysers, but for only very brief intervals. Measured concentrations of $\mathrm{H}_{2} \mathrm{~S}$ at the fence line of a Geysers power plant without abatement were 1.0 ppm maximum and averaged 0.2 ppm over an 8-hour period. Ambient levels during nocturnal inversions in the Big Sulphur Creek watershed under nonabatement conditions, w1th 11 units operating, average $0.1-0.2 \mathrm{ppm}$ (Malloch et al., 1979).

The phytotoxic effects of chronic, very low level exposure of native vegetation to $\mathrm{H}_{2} \mathrm{~S}$ or $\mathrm{SO}_{2}$ are unknown. Low levels of $\mathrm{H}_{2} \mathrm{~S}$, such as those observed at The Geysers, have been shown to stimulate growth in studies on cultivated plants, such as grapes (e.g., Thompson and Kats, 1978). Bennett, et al., (1974) argued that plants that are adapted to low pollutant concentrations may

\footnotetext{
${ }^{*} \mathrm{H}_{2} \mathrm{~S}$ may be responsible for the reduction in diversity and abundance of lichens within .62 miles of PGandE Units 1 - 6 (Malloch et al., 1979).
} 
be at a disadvantage when grown in the absence of pollutants (as in the control In the Thompson and Kats study). Thus, the growth stimulation noted by Thompson and Kats (1978) may indeed be related to a fertilizing effect (as they suggest) or due to adapted tolerance (as suggested by Bennett, et al.). This disparity demonstrates a current lack of understanding about the effect of air pollutants on vegetation. Even where growth stimulations are known to occur as a result of pollutant exposures, there are differing opintons as to the "benefit" of such a phenomenon. Some plant ecologists (e.g., Winner, 1981) view the potential stimulatory affect from air pollution to be a type of "terrestrial eutrophication", which may substantially, alter the composition of native ecosystems.

Acid Rain Formation--Hydrogen sulfide emissions in The Geysers area have prompted speculation concerning the formation of acid rain (e.g., Axtmann, 1975; ECOVIEW, 1976a; EPA, 1977; U.S. Fish and Wildlife Service, 1978). The effects of acid rain on ecosystems are not completely understood, but can include acidification of lakes and rivers and modification of soil nutrient leaching rates. If acid rain formation is to occur in The Geysers area, hydrogen sulfide released into the atmosphere must be converted to sulfur oxides. These undergo further reactions to produce sulfuric actd, which eventually returns to Earth in rain (Ehrlich et al., 1977).

Only one acid rain survey has been conducted in The Geysers area (Ebbeson, 1978). Samples collected from three stations after eight different rain events did not show any statistically significant differences in acidity. Transport of hydrogen sulfide and sulfur oxides in sufficient quantities to cause acid rain formation in agricultural areas adjacent to The Geysers appears highly unlikely, considering the effects of dilution and the reduction in hydrogen sulfide emissions due to abatement efforts. 
Climate Modification--Evidence for localized atmospheric changes due to steam emissions is anecdotal. Increased fog formation in cold weather is said to occur within one mile of geothermal power plants (SRI, 1977). This is belleved to be a consequence of the large increases in atmospheric water vapor and chemical and particulate nuclei that accompany steam emfssions (ECOVIEW, 1976b). ECOVIEW (1975b) suggests that Increased humidity may result in increased disease incidence in vegetation. At present, a quantitative basis for determining a relationship between power plant emissions and fog incidence does not exist. In the absence of this data, it is not possible to draw conclusions concerning disease incidence in vegetation.

Mechanical Damage-Minor sources of vegetation damage have been associated with steam well operations. Vegetation adjacent to several well pads at various sites has been damaged by scalding and coating of leaf surfaces with condensate (Atlant1s, 1976). Fine sand blown out of a Shell 011 Company well temporarily damaged some vegetation within a half mile radius of the well (ECOVIEW, 1976b, 1978).

Staff Position--Fron the data above, it appears that the most significant source of indirect vegetation Impacts is exposure of vegetation to boron from the cooling tower drift. Impacts of boron drift around individual power plant sites Include both damage and some actual vegetation loss. Of additional concern is the potential for cumulative impacts from full geothermal development which, could lead to chronic low level exposure of vegetation to drift contalning boron over large areas.

The site-specific issue of the effects of boron on vegetation from cooling tower drift has been raised by staff in all geothermal regulatory cases. The 
potential for cumulative regional effects has been raised by staff in The Geysers 16 and 17 cases.

Monitoring has been required by the Commission on a site-specific basis for drift effects, particularly those caused by boron. PGandE is conducting a study of the extent of drift effects as a permit condition for Unit 17. This study includes effects at four different power plants. Sufficient information is not currently avallable for a determination of low level chronic cumulative effects, if any, to be made. However, as more information is gathered in PGandE's ongoing study and other power plant monitoring programs, staff will attempt to develop a position on the potential cumulative impacts due to cooling tower drift from the combined power plants in The Geysers.

While not considered as a primary concern at this time, other indirect vegetation impacts, including acid rain, local climate modification, and low level chronic exposure to hydrogen sulfide emissions, may cause adverse vegetation effects and/or possible changes in species composition as the geothermal power plant density and size of the development increases.

Proposed Solutions--Site-specific monitoring should be used by staff to determine the severity and acceptability of local boron drift effects and to predict the potential for significant cumulative effects resulting from full field geothermal development. Spot monitoring should be initiated to detect cumulative chronic low level boron impacts and the other potential impacts if they appear as full geothermal development occurs. These monitoring efforts will require a continuing cooperative effort between the CEC staff and applicant utilities. 
CUMULATIVE WILDLIFE IMPACTS

WILDLIFE INTRODUCTION

The Increased demand for geothermal energy has changed the originally percelved Geysers geothermal development level of few megawatts and a few power plants to a large geothermal energy park. The expanded geothermal development changes the Impacts on wildlife resources from an area which previously had limited logging and cattle grazing as potential conflicts with wildiffe to an area now being subject to an industrial type of development. These potential Impacts affect the area's abundant and diverse wildife, as well as a few legally protected specles (rare, endangered, fully protected) and species of special concern. This section Identifies the known information about these species, the potential cumulative impacts from full geothermal development, and the CEC staff recommendations to effectively quantify and resolve potentlal development conflicts.

\section{WILDLIFE SPECIES}

Approximately 13 amphiblan specles, 21 reptile specles, 51 mammal species, and 132 bird specles have reportedly been found or are expected to be found in the KGRA (Meneghin et al., 1978). This diversity is a reflection of the numerous types of plant communities present, each providing habitat for different numbers and species of animals. A brief listing of the fauna of each habitat type is avallable in Appendix $C$.

A small number of wildife species in the KGRA are listed as endangered, rare, or fully protected (Table 7). The endangered southern bald eagle (Hallaeetus leucocephalus leucocephalus) is known to occur or have occurred recently in the RGRA (SRI, 1977). From July 1974 to March 1978, 11 sightings of the endangered American peregrine falcon (Falco peregrinus anatum) have been made 
Table 7

PRELIMINARY LIST OF RARE, ENDANGERED, AND PROTECTED

WILDLIFE SPECIES OF THE KGRA

\section{Endangered Species}

Southern bald eagle (Haliaeetus leucocephalus leucocephalus)

Peregrine Falcon (Falco peregrinus anatum)

\section{Rare Species}

Yellow-billed cuckoo (Coccyzus americanus occidentalis)

\section{Fully Protected}

Ring-tail (Bassariscus astutus)

Golden eagle (Aquila chrysaetos)

Species of Special Concern*

Long-eared owl (Asio otus)

River otter (Lutra canadensis)

California red-legged frog (Rana aurora)

Federal Status Undetermined*

Burrowing owl (Speotyto cunicularia hypugaea)

Osprey (Pandion haliaetus carolinensis)

Red-shouldered hawk (Buteo lineatus)

*Lack legal status and protection as rare and endangered

SOURCE: C.D.F.G., 1977

Meneghin et a1., 1978

PG\&E, 1977b

S.R.I., 1977 
whin the KGRA (Meneghin et al., 1978). Peregrines nesting near Mt. St. Helena have successfully fledged young and are reported to be doing well (GRIPS, 1980). The rare yellow-billed cuckoo (Coccyzus americanus occidental1s), the fully protected ringtall (Bassariscus astutus), and the golden eagle (Aquila chrysaetos) also occur in the KGRA.

Other species of spectal concern that are being considered for protection include the Callfornia red-legged frog (Rana aurora draytoni), the river otter (Lutra canadens1s), Iong-eared ow1 (As1o otus), burrowing ow1 (Speotyto cunicularle hypugea), osprey (Pandion hallatus carolinensls), and red-shoulder hawk (Buteo Ineatus).

The fully protected ringtall is known to utilize the steam-dominated portion of the geothermal area, and it appears there is a viable breeding population present (Kock and Brody, 1981). The endangered peregrine falcon forages in the steam-dominated portion and nests in the vicinity, although until the steam-dominated resource boundary is better defined, it cannot be stated with certalnty that a breeding population exists within the steam-dominated area.

Peregrine Falcon--The peregrine falcon population's precipitous decline in North America over the last 30 years has resulted in the elimination of this specles from most of its former range. In Callfornla, almost all of approximately 100 historlcal nesting sites are currently unoccupied, with only a remnant population existing in the northern part of the state. The KGRA is one of the few areas in California in which the peregrine is successfully reproducing. The potential threat to the continued survival of the peregrine due to encroaching geothermal energy development is therefore an issue of concern (KIrven, 1980). 
of the 11 peregrine sightings reported between 1974 and 1978, at least four may be of questionable validity. Surveys of Cobb Mountain, reported to have been the site of a nesting eyrie, have ylelded no evidence of peregrine activ1ty or presence (Stager, 1976).. The eyries in the KGRA known to be active nesting sites are located in the Mt. St. Helena and Palisades - Table Rock areas, officlally designated Critical Habitat Zones (Figure 11).

Located $6 \mathrm{~km}$ from a geothermal development site in the Briggs Creek drainage, the Mt. St. Helena eyrie is closest to geothermal development and has been occupied from 1970 - 1973 and 1977 to the present (Enderson and Kirven, 1980). During a 5-year period, 14 young have fledged. This is an average of 2.8 young per year. The fledging success at this site is considered to be exceptionally high in light of the widespread reproductive failure of the species elsewhere in North America (Kirven, 1980). A 1979 foraging behavior study of the Mt. St. Helena peregrines concluded that the falcons were relatively nonselective in their choice of foraging flight direction and returned with prey from the direction of the geothermal area on 17 percent of all such flights.

Because of the generally high abundance of prey around the eyrie, the loss of foraging resource due to the development of a small geothermal site is not believed to be significant (Enderson and Kirven, 1980). However, widespread industrial, residential, or agricultural development of the area w111 11kely threaten the long-term survival of the species in this location. Extensive foraging habitat loss plus increased human access and disturbance are significant threats to peregrine reproductive success (Kirven, 1980). 


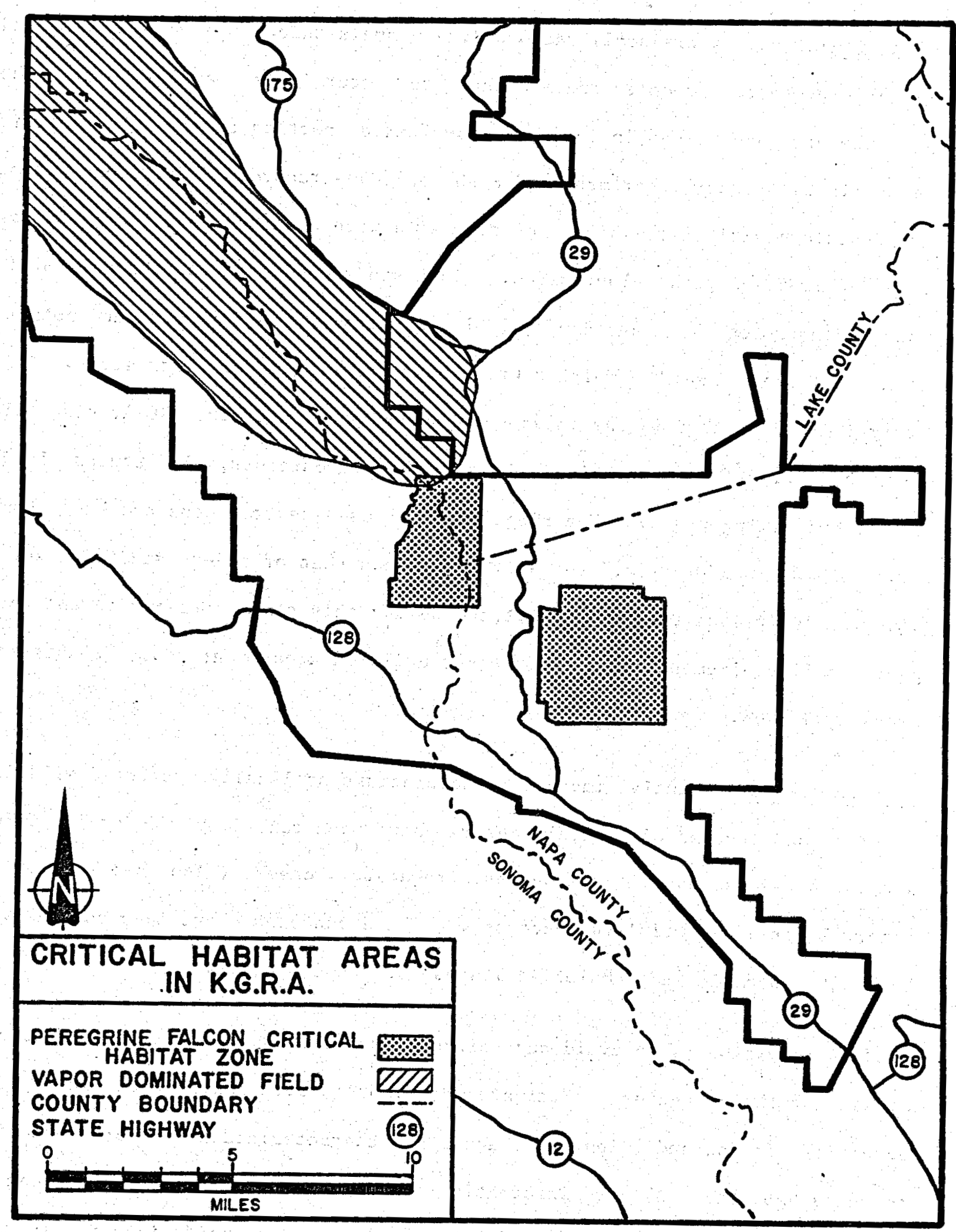

FIGURE 11: PEREGRINE FALCON CRITICAL HABITAT ZONE 
Ringtail--Ringtalls are small raccoon-like mammals which have been designated as fully protected species and are known to cccur in The Geysers KGRA. The presence of populations in the steam dominated portion of the reservoir is noted In California Department of Fish and Game records. In recent power plant sitings activities, signs of ringtails were observed near both Geysers 18 and SMUDGEO $\$ 1$ power plant sites. In a study conducted for the California Energy Commission (Koch and Brody, 1981), ringtails were collected and populations monttored along Big Sulphur Creek near existing power plant sites. This study indicates that in the steam-dominated portion of the KGRA, ringtails occur near riparian zones, often denning in rock outcrops, old stumps, large snags, and living trees. The ringtalls each used several dens and had a home range of 400 to 500 acres, a density lower than that of other studied populations. Individual ringtails monttored during this study appeared to tolerate geothermal development and in some cases utllized areas near power plants and s team well pads.

Staff Position--Potential impacts to populations of legally protected wildife species and specles of special concern have been raised by CEC staff, CDFG, and USFWS as issues in all Geysers regulatory cases (also see following materlal for other wildlife concerns). These concerns have been volced over both site-specific and cumulative losses for these species.

Staff's position is to avold any direct loss of breeding or other critical areas for these species. Estimates of impacts for all specles except the peregrine falcon and ringtail have been characterized as minor losses of foraging habitats. As more information on the peregrine falcon, golden eagle, and ringtail is developed, it will be possible to quantify impacts in more definite terms, hopefully resulting in satisfactory protection for these spectes. 
Present geothermal development has not been considered a significant threat to peregrine falcon foraging areas because of the distance from known active eyries In the Mt. St. Helena and Pallsades - Table Rock Critical Habltat Zones. Any geothermal development expansion into the southeast portion of the vapor-dominated geothermal fleld must be carefully evaluated and monftored for potential effects on peregrine foraging areas. Development of the Pacific Coast Recovery Plan for the American peregrine falcon is nearing completion. The Geysers-Calistoga KGRA lies within a proposed high peregrine falcon density management area in the recovery plan: Compatibility between geothermal resource development and the peregrine falcon recovery plan will require careful analysis and coordination. Colifsions with transmission lines is considered a common mortality factor for this species, and as a result the CEC staff is concerned about the location of future transmission line corridors with respect to known peregrine falcon eyrles and foraging areas. At present, the significance of these collisions for the local peregrine falcon population has not been assessed, but plans are now under way to evaluate this impact.

Because of concern for potential Impacts to the ringtall, the Commission sponsored a study to determine the occurrence, distribution, and habitat preference of this specles in the dry steam resouce area. This study confirmed the presence of the ringtall and has identified riparian and mixed evergreen forest habitat types as important habitat for this species. Based on these results and other demonstrated wildiffe values of riparian habitats, It Is staff's position that geothermal development should avold disturbance to riparian habitats. If potentlal impacts on riparian areas are likely from a geothermal project, site-specific studies should be conducted to determine the 
presence of ringtails and their usage of the specific area so that appropriate mitigation plans can be developed.

Proposed Solutions--The CEC staff w11 take an active role in coordinating with the state and federal Pacific Coast American Peregrine Falcon Recovery Team. Maximum coordination, Including possible participation in interagency contract studies, will assure early and adequate planning for geothermal energy development. Studies will consider potential eyrie and critical foraging locations and allow cooperative development of mitigation measures which can be incorporated into geothermal development plans. Simflar efforts will be undertaken to address concerns for the golden eagle.

To avoid significant impacts to ringtail populations, geothermal development should be avolded in riparian zones and other physical features used by ringtalls for denning, such as rockpiles, snags, and large mature trees, unless the applicant can adequately demonstrate that the area is not being used. The Commission should support additional studies to determine ringtail activities, behavior, and habltat preference during other seasons and in other areas of the KGRA.

\section{WILDLIFE HABITAT LOSS}

The primary wildlife impact is loss of habitat, which results in an absolute reduction in species abundance, and an overall reduction in an area's ability to support wildife. Because development occurs in a variety of habitats (Table 8), and wildlife have different habitat requirements (Table 9), differential mortality and displacement of wildlife species occur. Although habitat destruction adversely affects some species, those preferring "edge" created by clearing activities are thought to benefit. Clearings in dense stands of brush will ald deer and other spectes by increasing browse edge, 
Table 8

PREDOMINANT VEGETATION HABITAT TYPES ADJACENT TO POWER

PLANTS IN THE GEYSERS KGRA

Vegetation Habitat Type

\begin{tabular}{|c|c|c|c|c|c|}
\hline Power Plant & $\begin{array}{c}\text { Mixed } \\
\text { Evergreen } \\
\text { Forest }\end{array}$ & $\begin{array}{l}\text { Northern } \\
\text { Oak } \\
\text { Woodl and }\end{array}$ & $\begin{array}{c}\text { Mixed } \\
\text { Chaparral }\end{array}$ & $\begin{array}{l}\text { Chamise } \\
\text { Chaparral }\end{array}$ & Meadow \\
\hline \multicolumn{6}{|l|}{ Operating: } \\
\hline PG\&E $1 \& 2$ & $\therefore$ & $x$ & & & \\
\hline PG\&E $3 \& 4$ & & $x$ & & & \\
\hline PG\&E $5 \& 6$ & & $x$ & & & \\
\hline PG\&E $7 \& 8$ & & $x$ & $x$ & & . \\
\hline PG\&E $9 \& 10$ & & & $x$ & $x$ & \\
\hline PG\&E 11 & & & $x$ & $x$ & \\
\hline PG\&E 12 & & & $x$ & & \\
\hline PG\&E 13 & $x$ & & & & \\
\hline PG\&E 14 & $x$ & & & & \\
\hline PG\&E 15 & & $x$ & 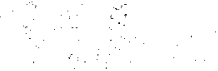 & & \\
\hline \multicolumn{6}{|c|}{ Under Construction: } \\
\hline PG\&E 17 & & & $x$ & $x$ & \\
\hline PG\&E 18 & $x$ & & . & & $x$ \\
\hline NCPA 2 & & & $x$ & $x$ & \\
\hline DWR Bottle Rock & $x$ & $x$ & 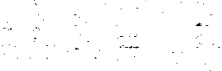 & $x$ & \\
\hline SMUDGEO 1 & & & $x$ & $x$ & \\
\hline \multicolumn{6}{|l|}{ Proposed: } \\
\hline PG\&E 16 & $x$ & & $x$ & & \\
\hline DWR So. Geysers & $x$ & $x$ & & & \\
\hline NCPA 1 & & $x$ & & $x$ & \\
\hline
\end{tabular}

SOURCE: CDWR, 1978, 1979; Malloch et a1., 1979; NCPA, 1978, 1979;

PG\&E, 1979b; SMUD, 1980. 
Table 9

FCOD AND HABITAT REQUIREMIENTS OF GAME SPECIES FOURD IN THE GEYSERS KGRA

Species
Gamebirds:
Mountain Quatl (Oreortyx
picta)
California Quail
(Lophortyx californica)
Mourning Dove (Zenaidura
macroura)
macroura)

Band-tailed pigeon (Columba fasciata)

Game Mammals:

Gray squirrel (Sciurus griseus)

Black-tailed Jack Rabbit

(Lepus californicus)

Brush Rabbit(Sylvilagus bachmani)

Hoofed Browsers:

Colunbian Black-tailed Deer

(Odocoileus hemionus columbianus)

\section{Description of Habitat}

Higher elevations; most abundant in serpentine chaparral

Cover edges; don't reach high population levels in large areas of thick. brush

Uses most habitat except deep forest, marshes or great expanses of open territory. Often have large range that Includes forage, water and roost areas at videly separated locations

Douglas fir, ponderosa pine forests

Open pine, oak woodland

Feeds in grassland. Takes cover during day in chaparral, woodland, forest habitats

Restricted entirely to mixed chaparral. Most abundant along chaparral-grass edge

Carrying capacities fluctuate over a broad range. Incouraged by establishment of herbs and sprouting shrubs as are present along ecotones
Food

Seeds (e.g. lupine); ants, beetles, grasshoppers

Feed primarily on forbs and grass seeds

Feed almost exclusively on grass.and forb seeds

Seed eaters; prefer acorns, pine seeds, fruit of dogwood or madrone

Acorns, seeds of ponderosa pine; other seeds, fungus

Filaree, other herbs

Herbs

Ceonothus, oak, deervetch, pine, manzanita, grasses

\section{SOURCE: CDWR, 1978; Martin et al, 1951; VTN Consolidated Inc., 1976}


Improving access, and producing larger quantitles of palatable vegetative growth. Many animals, Including brush rabbits, qua11, and deer, will ut1lize openings in the brush for feeding areas adjacent to a cover habitat (Atlantis, 1975). The amount and benefit of edge depends on where the edge is created. For example, it is difficult to get an edge effect in the middle of a grassland or meadow, whereas in a chaparral community, edge benefits depend on the age of the surrounding chaparral specles. The assumed benefits of increased edge have not been documented by field work in The Geysers.

Between April 1976 and July 1976, a preliminary investigation of geothermal development Impacts in The Geysers KGRA on wildiffe population distribution and abundance was made by Individuals from both the public and private sectors. The product of this cooperative effort, The Geysers wildlife Study (PGandE, 1977b), was the most comprehensive wildlife census conducted in the KGRA. The study evaluated census results from geothermally developed and undeveloped sites in six habltat types: oak savannah, oak woodland, mixed evergreen forest, chamise chaparral, mixed chaparral, and riparian. Preliminary results, which have yet to be statistically confirmed, indicated that some wildife population densities (e.g., songbird, amphiblan) were lower in geothermally developed areas as compared to geothermally undeveloped areas (Table 10).

Because this study was conducted over only a brief interval, it is uncertain If the observed differences will be borne out over a long period of time. The long-term 1mpacts on species diversity and density due to continued habitat destruction and resultant division of habitat into discontiguous patches is unclear. Wldlife using habitat patches near developed areas are subjected to 
Table 10

SUMMARY OF THE GEYSERS WILDLIFE STUDY: PRELIMINARY RESULTS

Amphibians:

Red-belTied newt (Taricha rivularis)

Rough-skinned newt (Taricha granulosa)

Foothill yellow-legged frog (Rana boylei)

Undeveloped

Undeveloped

Undeveloped

Reptiles:

Western aquatic garter snake (Thamnophis couchi)

Undeveloped

Western pond turtle (Clemmys marmorata)

Western fence lizard (Sceloporus occidentalis)

oak savannah; chamise chaparral

oak woodland; riparian

Other lizards, snakes

Undeveloped

Developed

Undeveloped

$N / A$

Birds:

Raptors

$N / A$

Owls

Songbirds

Wrentit (Chamaea fasciata)

Mixed chaparral

Rufous-sided towhee (Pipilo erythrophthaimus)

Mixed chaparral

Black-headed grosbeak (Pheucticus melanocephalus)

Riparian

Not species specific

Mixed chaparral

Mixed evergreen forest

Oak woodland

Oak savannah

Riparian

N/A

Undeveloped

Undeveloped

Undeveloped

Undeveloped

Undeveloped

Undeveloped

No Difference

No Difference

Mamma 7s:

Bats

Small mammals

Western gray squirrel (Sciurus griseus)

Mixed evergreen fores $t$

Oak woodland

Carnivores

Deer, rabbit, cattle

N/A

N/A

Undeveloped

Undeveloped

N/A

$N / A$

Symbols: NA: Data unavailable or insufficient for analysis

SOURCE: PG\&E, 1977b 
potentially detrimental disturbance from nolse and 1ncreased human activity. As In the case of edge effects, the consequences of Increased habitat patchiness are unknown.

Staff Position--The 1ssue of wildiffe loss associated with alteration and removal of habitat has been raised by CEC staff, CDFG, and other intervenors in all Geysers regulatory cases. Concerns have been raised regarding both site-specific and cumulative losses. Only the wildiffe losses directly assoclated with power plant facilities for each geothermal development have been presented or mitigated. Losses from well field or road development have not been adequately dealt with.

Staff has indicated concern for habltat loss and the assoclated loss of wildIffe in both past and current power plant proposals. The final decisions and the compliance monitoring programs for the power plants which have been certified by the Commission verify both the Commissioner's and the staff's commitment and concern for wildife populations and their habitat. Staff concern is for all wildlife specles, but primary emphasis has been placed on legally protected species, recreational specles, and specles of spectal concern. It is staff's position to continue emphasizing the importance of wildiffe populations in planning for geothermal development in the Geysers KGRA.

Proposed Solutions--Staff will continue to require mitigation efforts which minimize the area of wildlife disturbance and enhance the habitat surrounding the disturbed areas. The enhancement techniques reduce the effects of habitat loss by improving the surrounding habltat for certain species, thereby 1ncreasing the habitat's capacity to support greater numbers of wildlife. 
Staff belleves that baseline and monltoring studies of mitigated and enhanced areas are important to provide valuable information 1dentifying the effectiveness of the implemented measures. This provides staff with valuable feedback on methods used to date, provides accurate information for decision making, and leads to mitigation and enhancement programs which benefit a larger portion of the biological resource.

In the past staff has emphasized site-specific mitigation, but off-site mltigation and compensation offers another acceptable alternative on a sitespecific basis. On a reglonal basis, on-site mitigation and enhancement does not adequately correct for the cumulative loss of habitat and wildife populations from full geothermal development. Off-site mitigation, enhancement, and compensation can, to a degree, offset cumulative wildife losses in The Geysers resulting from full geothermal development resource. Staff proposes to produce detafled vegetation maps of The Geysers KGRA so that the significance of vegetation and wildlife habitat losses can be evaluated on a cumulative basis. To adequately mitigate for losses, identification and preservation of representative and unique habitats may also be necessary.

In summary, offsetting significant adverse wildife impacts resulting from full geothermal development will require the use of all avallable methods, including on-site mitigation to minimize disturbance, utilization of proven and promising enhancement techniques, careful monitoring to ensure maximum effectiveness, and off-site mitigation and compensation to preserve representative and unique habitats. 
Nolse-Wildiffe are exposed to noise during all phases of geothemal development; venting of steam is the loudest noise and can reach $100-125 \mathrm{dBA}$ at 20 to 100 feet. Most of the other nolse sources fall below $100 \mathrm{dBA}$ and are those usually assoclated with construction and Industrial projects (Leitner, 1978a). Preliminary results of nolse studies on various wildife specles indicate that moderately increased sound pressure levels characteristic of developed areas at The Geysers are not accompanied by drastic changes in wildlife communities. There is some evidence that certain species may be depleted in noisy areas, but there is no proof that noise is the causal factor (Leitner, 1978b).

Cooling Tower Drift--The damage to 247 acres of vegetation caused by cooling tower drift has reduced the quality of the forage and habitat for wildife. Oak species, chamise, buckeye, and poison oak have been moderately to severely damaged at Units $1-11$ (Table 5). All of these plants are significant browse specles for deer (PGandE, 1978).

Trace Metals--Geothermal steam contains very small concentrations of arsenic $(0.019 \mathrm{ppm})$ and mercury $(0.0050 \mathrm{ppm})$. Arsentc is released from cooling towers In the form of suspended droplets entralned in drift. Although some of the small amount of mercury which is released is in the form of insoluble mercuric sulphide, 50 to 67 percent of the mercury released from power plants is in gaseous elemental form. Annual arsenic deposition at the fence line at PGandE

\footnotetext{
*Sound pressure level weighted in accordance with the " $A$ " scale. A-weighted scale expresses the relative Intensity of sounds, similar to the response of the human ear. One dBA represents the faintest audible sound; 50 to $60 \mathrm{dBA}$ represents normal conversation at three to five feet (Keezer, 1976).
} 
Units 5 and 6 is estimated to be 0.27 pounds/acre, a concentration four orders of magnitude less than that used for herbicidal purposes. Mercury concentrations in cooling tower exhaust air have ranged from 0.02 to $0.2 \mathrm{ppb}$ (Malloch, et al., 1979).

Because arsenic and mercury can have detrimental effects on vegetation and wildlife, the possible accumulation of these metals in terrestrial and aquatic food chains must be evaluated. Information on accumulation rates, concentrations in vegetation and wildife, and the rates at which these metals are transported to streams is unavailable. Without further research it is impossible to assess the present or future significance of this issue.

Staff Position--The other wildife impacts, including noise, drift, and trace elements, have not been raised before the Commission as issues in Geysers regulatory cases. On a site-specific and cumulative impact basis, these concerns have not been considered significant when compared to other causes of wildlife loss.

Noise impacts are closely associated with power plant and steam field construction activities. Both of these activities are considered temporary even though they may occur during several years of construction. Noise levels at operating power plants and well pads (when steam releases are muffled) do not seem to significantly reduce wildiffe use of adjacent habitats.

As discussed previously, wildife habitat loss is a general concern of staff. Present levels of vegetation loss and damage from cooling tower drift contribute to this general concern. However, the wildife habitat loss resulting from drift is hard to quantify and has not been 1solated as a separate concern from general habitat loss. PGandE is studying the extent of observed annual 
increases in vegetation damage. The results of this study will be used by staff to further evaluate the the potential significance of wildife habitat loss from cooling tower drift.

At present levels; toxic trace metals do not appear to be contributing to the loss of wildlife or their habltat. Potential impacts caused by toxic trace metal accumulations in the food chain need to be examined further and monitored as geothermal development proceeds.

Proposed Solutions--The following recommendations are made by staff:

- Nolse from muffled steam venting and current levels do not require additional attention to reduce impacts on wildlife.

- Staff will review the results of ongolng cooling tower drift studies to determine if potential wildife habltat losses are significant and to determine appropriate mitigation measures.

- Staff recommends that the Commission support the development of a program to monitor toxic trace elements in wildlife food chains. Development of this program will require a baseline study to establish existing levels of toxic materials.

\section{EE-19 CUM}

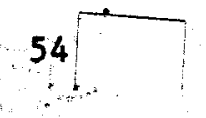



CUMULATIVE AQUATIC BIOTA IMPACTS

\section{EROSION AND SEDIMENTATION}

The rock units underlying major portions of The Geysers KGRA (mainly in the Mayacamas Mountains) are assigned to the Franciscan assemblage (Figure 5). Th1s assemblage is generally unstable under natural conditions because of chemical alteration, innumerable faults and shear zones in the rock and the presence of complex matrices of metámorphic rocks (melange). Interference with the natural balance between such factors as natural slope angle, groundwater, vegetation, and surface loading can result in downhill soll and rock creep, slope fallure on rock of the Franciscan formation, and particularly on the melange matrix (Figure 12), and in undercutting roads and other facilities. Removal of vegetation in The Geysers area destroys the network of roots which bind the unstable soll materials together and, more importantly, destroys the vegetative canopy which retards, runoff and reduces erosion (Bacon et al., 1976).

Consequences of Vegetation Removal--In this region characterized by a heavy winter rainfall, highly erodible solls and steep topography, vegetation removal and construction activity are of particular importance (Leitner, 1978b). For example, at the Unit 17 site, soll losses are 1.0 ton/acre on north-facing slopes and 1.3 tons/acre on south-facing slopes and are expected to Increase to 20 tons/acre (north-facing slopes) and 25 tons/acre (southfacing slopes) during construction (PGandE, 1979a). It is estimated that 30 percent of the soll lost during construction, or 6 to 8 tons/acre, finds its way into streams. This is approximately six times greater than existing 


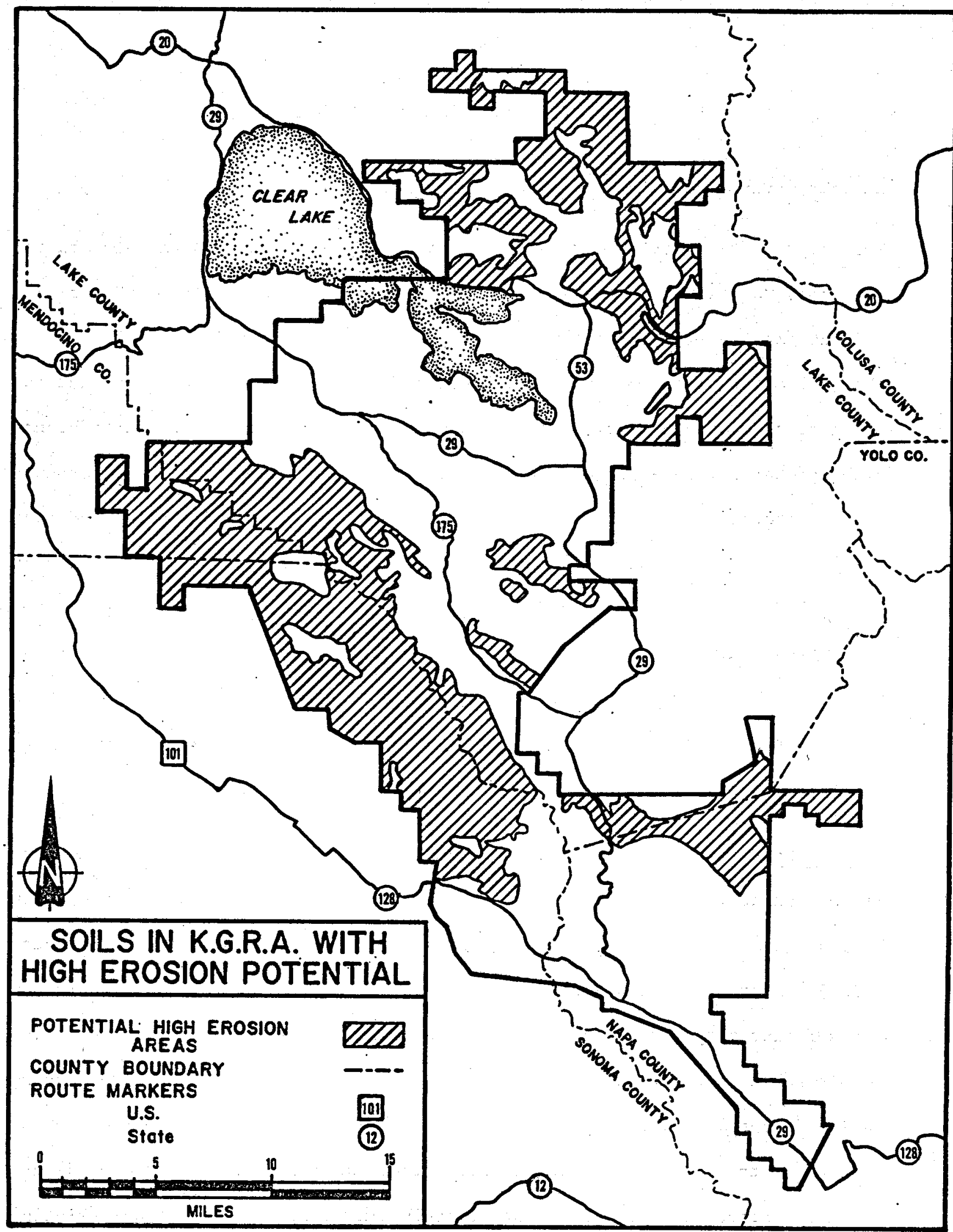

Source: Modified From SRI, 1977b.

FIGURE 12: MAP SHOWING SOILS WITH HIGH EROSION POTENTIAL 
erosion and sedimentation rates. These figures are consistent with observations in the California North Coast Ranges, where rural construction increased sedimentation rates six times the normal rate (California Division of Forestry, 1972). Although a three-month winter moratorium on construction in The Geysers undoubtedly reduces soll losses, losses from soll surfaces exposed during premoratorium construction continue during heavy rainfall periods. $f$

With proper revegetation and englneering practices, soll erosion and sedimentation due to power plant site construction are short term; however, road development creates long-term disturbances. Road construction in other small, steep watershed areas Increased sedimentaton by an estimated 30 times over rates from comparable undisturbed forested areas (California Division of Forestry, 1972). Erosion Increases exponentially as road density (miles of road per square mile) increases. For example, estimates of erosion caused by road development show a sixfold increase as road density doubles (CEC, 1979a). Furthermore, the larger the cuts and f1lls, and the steeper the terrain traversed, the greater the erosion and sedimentation resulting from road construction. Steep crossroads result in higher cuts, longer fill slopes, and greater areas exposed to erosion for a given road width (California Department of Conservation, 1971).

Vegetation removal, especially due to road construction, in a region already erosion prone, exacerbates the existing condition. Without mitigation, construction activities could increase soll erosion twentyfold over background rates (CEC, 1979d). Because field measurement of natural erosion rates for the KGRA exist only for a few sites, it is not possible to accurately estimate cumulative soll losses. However, if background losses are assumed to be 1 
ton of soll per acre per year,* then losses due to construction could be 20 tons per acre per year. Based on the cumulative vegetation loss estimates (Table 4), development-induced soil losses for the KGRA could range from 22,000 tons/year to 70,400 tons/year under the Low Scenario, and from 44,000 tons/ year to 140,800 tons/year under the High Scenario. These estimates are not exact, but they illustrate the potentially enormous increases in erosion that are possible if mitigation measures are not uniformly implemented.**

In addition to the removal of protective vegetation, geothermal development operations can alter runoff rates and activate landslides (Leitner, 1978b). Tables 11 and 12 document the number of geothermal facilities (power plants and steam we11s) built on unstable terrain. Ninety-one of 168 we11s 1isted in the table ( 54 percent) are located on landslides. Units 1 and 2 and 3 and 4 are located on slides, while Units 5 and 6,12 , and 14 are located close to slides.

IMPACTS ON AQUATIC BIOTA

The KGRA encompasses six major areas of significant value to fisheries (Figure 13): (1) the watersheds west of the Mayacamas Mountains, whose streams are tributary to the Russian River by way of Big Sulphur Creek and smaller drainage ways; (2) the Putah Creek Watershed; (3) the Kelsey Creek Watershed; (4) the Cache Creek Watershed; (5) Thurston Lake and Its watershed; and (6) Clear

\footnotetext{
*Losses at Unit 17 are 1 ton soll/acre/year (PGandE, 1978) and 3 tons/acre/year at Unit 18 (CEC, 1979d). Vegetation, soll types, and topography of these sites are similar to those found at some of the other power plant locations.

**Discrepancies exist between mitigation measures required by local authorities and those required by the state, e.g., the CEC.
} 
Tahle 11

TERRAIN ANALYSIS OF GEOTHERMAL WELIS

\begin{tabular}{|c|c|c|}
\hline $\begin{array}{l}\text { Location } \\
\text { of. Well }\end{array}$ & $\begin{array}{l}\text { Total Wells } \\
\text { In Section }\end{array}$ & $\begin{array}{c}\text { Wells } \\
\text { On Landslide }\end{array}$ \\
\hline Sec. 6, TIIN, RSW & 7 & 3 \\
\hline Sec. 7 & 14 & 9 \\
\hline Sec. 17 & 4 & 2 \\
\hline Sec. 18 & 14 & 4 \\
\hline Sec. 19 & 1 & 0 \\
\hline Sec. 20 & 14 & 1 \\
\hline Sec. 26 & 6 & 1 \\
\hline Sec. 27 & 3 & 1 \\
\hline Sec. 28 & 3 & 3 \\
\hline Sec. 29 & 1 & 0 \\
\hline Sec. 30 & 1 & 0 \\
\hline Sec. 33 & 2 & 2 \\
\hline Sec. 34 & 2 & 1 \\
\hline Sec. 35 & 1 & 0 \\
\hline Sec. $1 ;$ TIIN; R9W & 6 & 4 \\
\hline Sec. 10 & 1 & 1 \\
\hline Sec. 11 & 9 & 7 \\
\hline Sec. 12 & 28 & 17 . \\
\hline Sec. 13 & 30 & 26 \\
\hline Sec. 14 & 20 & 8 \\
\hline Sec. 35, TI2N, E9W & 1 & 1 \\
\hline Totals & 168 & 91 \\
\hline
\end{tabular}


Table 12

TERRATN ANALYSIS OF GEOTHERMAL POWER PLANIS

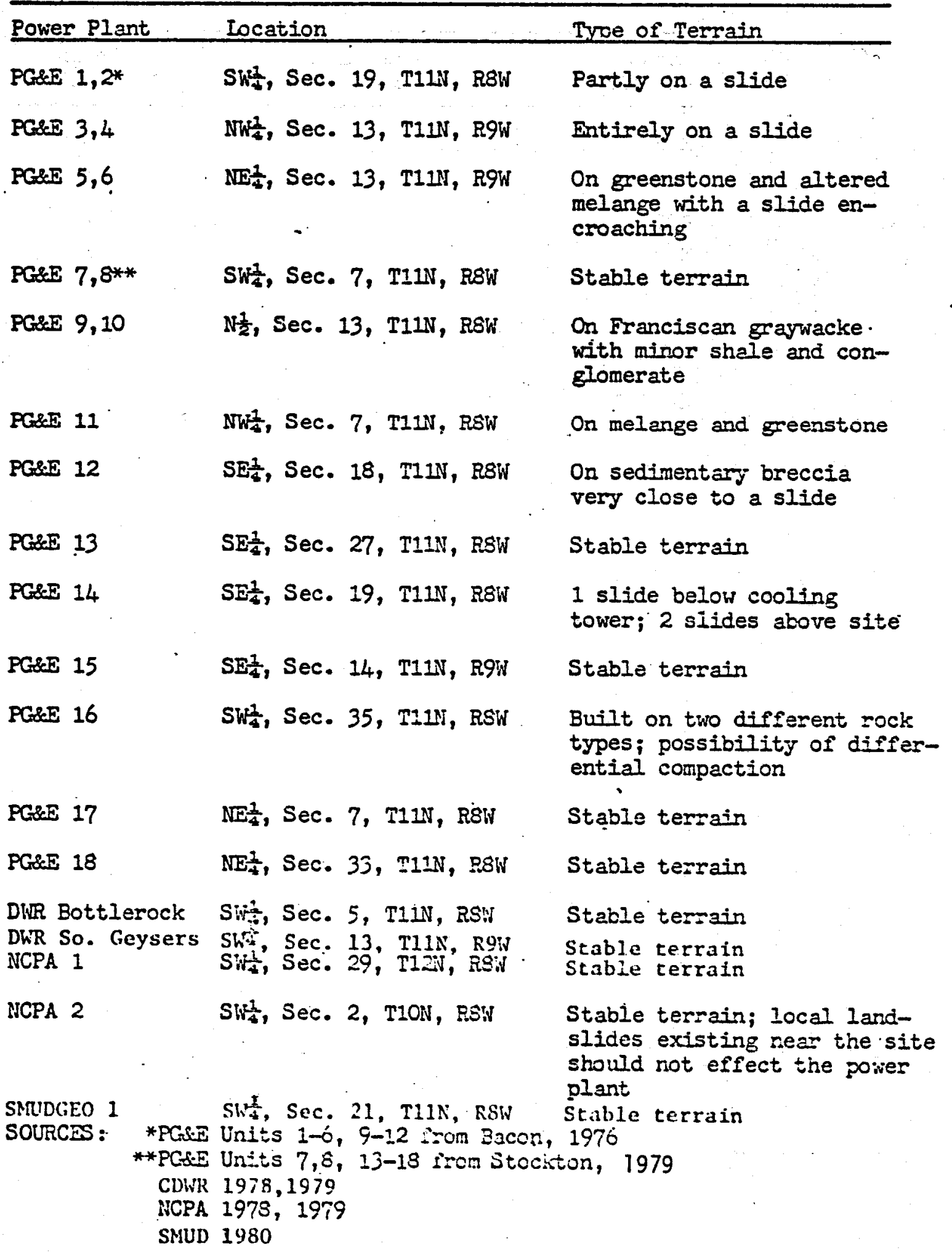




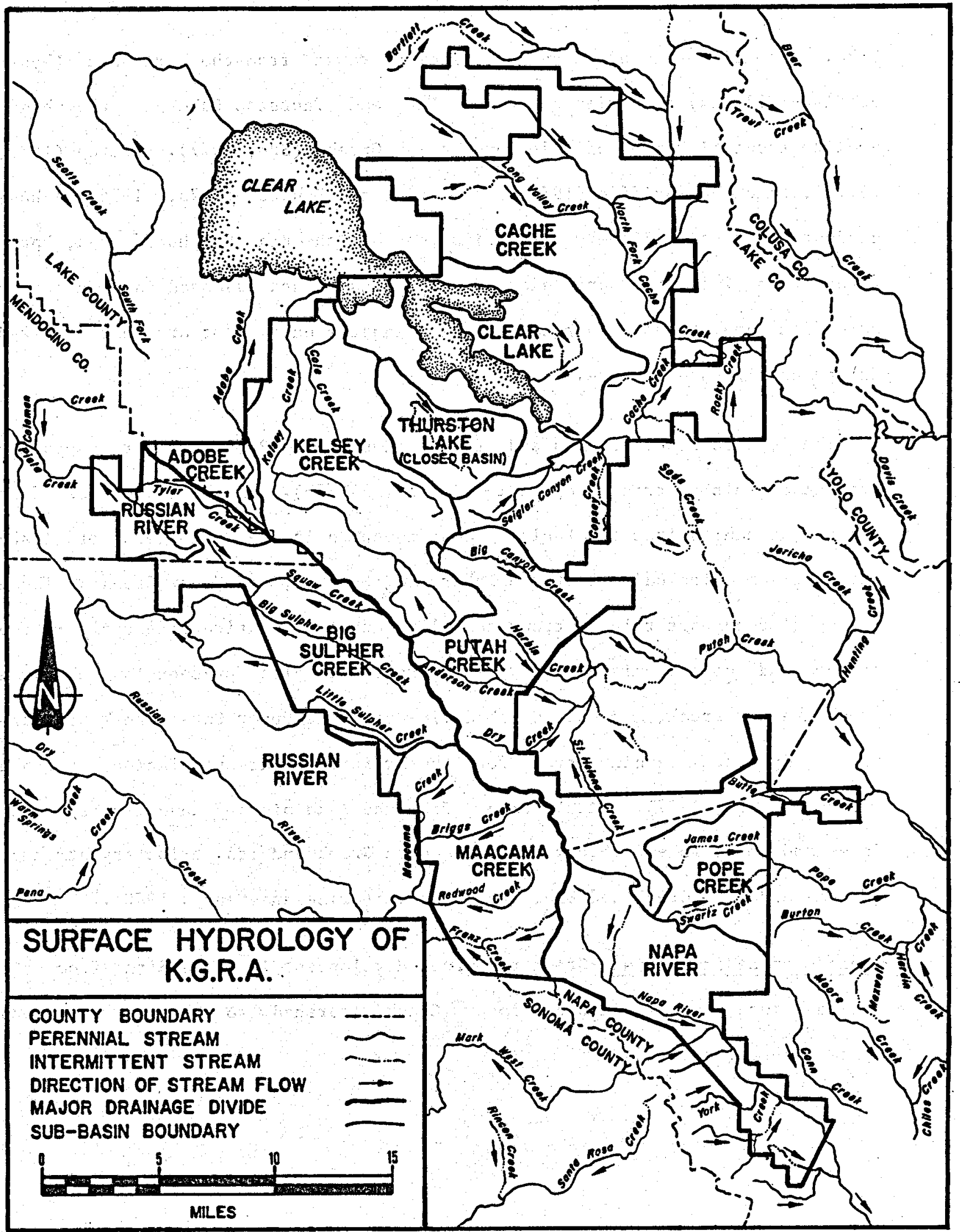

Source: Modified From SRI, $1977 \mathrm{~b}$.

FIGURE 13: SURFACE HYDROLOGY MAP 
Lake. The fisheries of these water regions range from the warm water (basscatfish-bullhead) fisheries of Clear Lake and Thurston Lake to the highquality trout flsheries of Cole and Kelsey Creeks (SRI, 1977). Price (1975, 1977a), Price and Griffin (1975), and Price and Kubicek (1975, 1976a,b) have conducted extensive fishery Investigations of the Big Sulphur Creek, Upper Putah Creek, Cole Creek and Kelsey Creek drainages and assessed game and nongame fish populations. In general, these aquatic ecosystems are characterized as "productive and diverse."

In The Geysers KGRA, streams and tributaries to the Russian RIver support a steelhead rainbow trout population (Price, 1977b). These anadromous fish migrate as adults from the Pacific Ocean to spawn in the headwaters of freshwater streams, Including Little Sulphur, Big Sulphur, and Squaw Creeks. These creeks also support rainbow trout that live out their entire life cycle in the streams and do not migrate. Rainbow trout are also present in the Putah Creek, Kelsey Creek, and Cole Creek drainages. The Upper Putah Creek Drainage is an important spawning area for the rainbow trout population in Lake Berryessa (SRI, 1977). Adult trout from the lake migrate annually up Putah Creek and spawn in suitable gravels in Putah Creek and its tributary streams, such as Anderson Creek and Bear Canyon Creek (Price and Geary, 1980).

Impacts of Sedimentation--Steam resource development is expanding from the original locations within Big Sulphur Creek watershed to those in Putah and Kelsey Creek (Table 13). 
Table 13

GEOTHERMAL DEVELOPMENT IN KGRA WATERSHEDS

B1g Sulphur Creek

Power Plant PGandE $1-12,14,15,17,18$ NCPA 2, SMUDGEO 1, DWR South Geysers

Steam Field PGandE 1-12, 14,15,17,18 NCPA 2, SMUDGEO 1, DWR South Geysers
Putah Creek

PGandE 13, 16 , OXY 1

PGandE 13, 16, OXY 1, NCPA 2
Kelsey Creek

NCPA 1, DWR Bottle Rock

NCPA 1, DWR Bottle Rock, PGandE 17

As the development process expands, the attendant surface disturbances are increasing erosion and sedimentation into KGRA streams (Figure 1). Increased sedimentation is of concern because of the well documented effects this process has on aquatic 1ife. Streambed sedimentation can damage trout spawning areas, decrease dissolved oxygen concentrations, block the emergence of fry, and destroy cover needed by trout (Price, 1977b). Sedimentation can also destroy favorable breeding sites for amphibians or prevent successful transformation of gilled aquatic larvae to terrestrial adults. Reduction in insect prey populations may in turn contribute to reduced survivorship of salmonid fry and amphibian larvae.

Results of several studies 11nk geothermal development to increased erosion and sedimentation in KGRA streams recelving runoff from disturbed areas. Fishery studies in the Big Sulphur Creek and Alder Creek drainages found significantly higher sediment levels in areas adjacent to geothermal operations, as compared to undeveloped areas (Steele, 1977a,b). Sediment levels were not yet high enough to Inhibit salmonld spawning in Big Sulphur Creek, but the levels did adversely affect trout populations in Alder Creek. This trout population was both smaller and in poorer condition than populations in undeveloped areas of Alder Creek. 
Price and Griffin (1975) conclude that flow, color, turbidity and settleable solids in Big Sulphur Creek and Squaw Creek increased over an 85-month period and that increases in these sedimentation indicators are linked to erosion due to expanding geothermal development. In a subsequent analysis using an additional year of data to that used by Price and Griffin (1975), Price (1977a) concludes that no link exists between geothermal development (as measured in MW) and stream condition parameters. However, an analysis by Pimentel (Pimente1, 1978; letter from Pimentel to L.A. Enriquez at PGandE, November 17, 1978) of water quality data in the two reports (Price and Griffin, 1975; Price 1977a) has led to the same conclusions originally reached in the 1975 report: that there is convincing evidence supporting a link between geothermal development and increased sedimentation.

When highly erosive soils, such as those in The Geysers region, are disturbed due to development of geothermal facilities, harmful effects can result from the subsequent soil erosion. Obvious signs of erosion are silt deposits and turbidity. Siltation and/or turbidity can alter stream bed characteristics, which will increase water velocities and force directional flow changes, leading to additional erosion and flooding. Changes in water quality constituents, increased temperatures, and algae/bacterla growth can result in less desirable biological productivity. Large amounts of sediment transported in streams can injure fish by physically damaging gill tissue and interfering with respiration. If eroded soil sediment settles in the stream beds, incubating fish and amphibian eggs as well as bottom dwelling aquatic insects can be smothered.

Impacts of Chemical Discharges--Additional threats to stream quality and aquatic fauna result from condensate spills and the discharge of drilling muds, 
waste materials, and detergent to streams (Appendix D). The 71 reported pollution Incidents between 1965 and 1980 are as follows: 33 condensate spills, 13 landslides and sedimentation incldents, 11 drilling-mud sump fallures, 4 spills of fuel oil or other petroleum products, and 10 cases involving well blowouts, spills of abatement chemicals, and other miscellaneous pollutants. of these reported incidents, only four fish kills have been documented since 1965. In addition, Department of F1sh and Game reports that the elimination of the young of the year, detected in their 1978 trout population survey in affected creeks, was due to the 250,000 gallon condensate spill on June 2, 1977 (Pimentel, 1978).

Toxlc materials can enter streams as a consequence of delivery truck accidents, such as the one which occurred on January 21, 1978 (Appendix D). Transport of sludge from cooling tower wastes and the dellvery of hydrogen peroxide to abatement systems is expected to require 3,340 trips per year ( 9.1 trips/day) for Units 1 - 18 (CEC, 1979d). Although it is not possible to predict how many accidents will occur, it is sufficient to note that accidents become more likely as truck traffic increases.

Release of toxic substances through splils which reach streams can cause either Immediate death or chronic physlological stress to aquatic organisms. Water quality conditions in an affected stream can of ten take weeks, months, or even years to return to normal. Toxicants can adhere to stream bed deposits or can remaln suspended within the water column. Absorbed spills flushed from the soll during spring runoff periods can also add toxicants to streams over a long period.

Staff Position--The issue of adverse 1mpacts on aquatic biological resources, particularly on steelhead and other trout spawning areas, has been raised by 
CEC staff, CDFG, USFWS, and other intervenors in all Geysers regulatory cases. Mitigation to reduce erosion and the containment of spills to protect the fishery resources has been evaluated for both the power plant sites and the supporting geothermal development.

It is the CEC staff position that there should be full implementation of mitigation measures on a site-specific basis to control erosion and spilis and that there be monitoring of these measures to assure their effectiveness. Power plant applicants have developed revegetation and erosion control plans, as well as plans and mitigation measures to reduce the potential for toxic spills. Within the CEC regulatory siting process, the CEC has required contaimment of chemical substances and wastes at power plant sites. In addition, CEC staff recommends that a long-term regional aquatic monttoring program be established to evaluate cumulative impacts on the affected watersheds.

Proposed Solutions--The staff should do the following:

1. Maintain present function of working with the utilities to more effectively control site-specific erosion and to contain spills of toxic substances.

2. Identify most sensitive areas so that development can avold highly erodible soils.

3. Continue preleasehold development environmental review, comment on measures to reduce unnecessary ground disturbance, and encourage implementation of erosion control measures.

4. Continue working with developers and agencies concerning toxic substance transport, storage, and disposal to minimize potential hazards. 
5. The CEC should continue to require regional aquatic resource monitoring (presently known as The Geysers KGRA-ARM Program) as a condition of geothermal power plant certification. These monitoring requirements should be coordinated with local and federal regulatory agencies so that regional cumulative impacts and the success of proposed mitigation measures can be determined in the most cost-effective manner.

\section{INJECTION}

Artificial recharge of the steam reservoir in the form of condensate injection has been practiced since 1969, with no observable decrease in the capacity of the reservolr to receive condensate.* Injected condensate is belleved to move slowly through the fractured reservolr rock, increasing in temperature, eventually vaporizing and ultimately reextracted. If injection continues at present rates, an additional 5 to 8 percent of the rock heat content may be extracted for power generation (GeothermEx, 1980).

Alternate methods of increasing the amount of water avallable for injection include the use of dry cooling towers and diversion of surface water from KGRA streams. If a method were developed to substitute dry cooling towers for the present evaporative type, it might be possible to reinject the entire condensate produced from the steam wells. The dual considerations of extra cost for dry cooling towers and uncertainty as to the optimum rate for injection have forestalled this development (GeothermEx, 1980).

\footnotetext{
*Approximately 20 percent of the steam supplied to power plants is condensed and reinjected via injection wells. One injection well is capable of handling condensate from five to eight production wells (GeothermEx, 1980).
} 
Diversion of surface stream water for purposes of injection has been started by the Union 011 Company of California, one of the principal steam suppliers in The Geysers. Union has constructed a water collection system in the bed of Big Sulphur Creek upstream from PGandE Units 1 and 2. The system has a pumping capacity of $2,000 \mathrm{gpm}$ and w111 operate about 6 months of the year, or the period during which stream flow exceeds 15 cfs. Annual water removal is approximately 1,600 acre-feet, or 518 million gallons (California Department of Fish and Game, 1978). Continued efforts by steam suppliers to expand their injection capacity by diverting or Impounding stream water can be expected in the future.

Staff Position--The issue of the use of surface waters for injection into the steam reservoir, if it becomes a common practice, will cause potential problems when combined with existing water diversions in maintenance of in-stream flows for aquatic biological resources, particularly flows adequate to maintain trout spawning areas.

This issue has not been raised in any geothermal power plant regulatory cases to date, since it is not a part of power plant operation but is confined to steam production. However, use of surface water for injection is being considered by steam developers in the RGRA along with the current practice of the reinjection of excess condensate to prolong the life of The Geysers KGRA steam resource. The water resources in the developed Geysers area are adequate to allow a reasonable level of development for this type of water use. However, restrictions on stream flow withdrawals and water storage are essential to protect aquatic biological resources and other beneficial uses.

Proposed Solutions--Staff should initiate a study to determine (1) how widespread the need to inject. will be in the future and (2) the potential of the 
streams in The Geysers KGRA to provide water and water storage sites for Injection purposes. Information on the existing and proposed placement, size, and use restrictions of such factilties should be made avallable to USGS, the Commission, U.S. Geological Survey, State Water Resources Control Board, Reglonal Water Quality Control Board, California Department of Fish and Game, and county representatives for review and comment. This information should be used to develop an acceptable regional plan for the long-term use of surface waters from streams within the developing portion of the geothermal resource area. 

SUMMARY AND CONCLUSIONS

SUMMARY

Geothermal generating capacity is profected to expand at the rate of $200 \mathrm{MW}$ per year for at least another 10 years. If ut1lity forecasts are accurate, capacity w111 reach 2,994 MW by 1990 . The vapor-dominated resource at The . Geysers will cover at least 25 square miles and may involve as much as 100 square miles. The most likely generating capacity from this fleld is assumed to be about $3,000 \mathrm{NW}$.

The temporal and spatial scale of geothermal energy development dictates the magnftude of cumulative biological impacts. Therefore, adequate information as to the spatial extent, operational lifetime, and megawatt potential of the steam resource is of central importance. Without accurate estimates of these factors or pollcy concerning management of short- or long-term energy production, it is difficult to predict the magnitude of cumulative Impacts except within very wide bounds. Therefore, three development scenarios of 2,000 MW, 3,000 MW, and 4,000 MW have been selected to demonstrate the range of impacts which may occur.

Vegetation--The focal point of present and future blological disruption in The Geysers is the $10 s s$ of and damage to native vegetation. The major Impacts on vegetation are (1) direct loss due to clearing for construction and (2) indirect loss and damage due to release of chemicals in the steam, Including the deposition of boron.

Direct vegetation losses range from 6.3 percent $(0.55$ acres $/ \mathrm{MW})$ to 20 percent (1.77 acres/MW) of the leasehold. The best documented estimate is 11.5 
percent $(0.93$ acres $/ M W)$ which amounts to an estimation of 1,137 acres for PGandE Units 1 - 18. Using the 0.93 acres/MW as a conservative estimate, there would be a loss of 2,790 acres associated with the development of 3,000 MW, or a potential loss of 5,280 acres if the 1.77 acres/MW 10 s occurred. The CEC staff position is to avold development on areas of rare or unique vegetation and to keep vegetation disturbance and loss to a minimum. If cumulative impacts from direct vegetation loss of full geothermal development are not mitigated, the potential impacts could be significant.

Indirect vegetation impacts include toxic elements from the steam emissions, acid rain, local climate modifications, and mechanical damage. Steam emissions contain elements which are toxic to vegetation in high concentrations. Stress and damage to vegetation from boron in cooling tower drift has been observed over 247 acres (6 percent) of the total leasehold area of PGandE Units 1 - 11. PGandE is currently conducting studies to quantify effects of airborne boron deposition. Changes in the design of new cooling towers may reduce this impact, although some effects from deposition near power plants are expected to continue. There is also concern about cumulative effects on vegetation from chronic low-level boron and hydrogen sulfide exposure. Concerns about Impacts associated with actd rain formation and localized climate modification have been expressed but are not well documented and are hard to quantify in The Geysers area. Mechanical damage, from steam scalding and from coating of leaf surfaces with condensate, has been restricted to very small areas and are considered minor sources of vegetation damage.

of these indirect impacts CEC staff considers the boron damage to be an important site-specific effect and have required monitoring of new power plant designs to determine if impacts are being reduced. While not considered by 
staff as a primary concern at this time the other potential indirect impacts should be monitored for adverse vegetation effects and/or possible changes in species composition as geothermal development increases.

The CEC staff recommends the following measures to reduce potentially significant direct impacts and to ald in determining the significance of Indirect impacts:

1. Development of Geysers resource maps showing detalled plant associations and the location and distribution of unique vegetation resources for use by permitting agencies.

2. Approprlate surveys of potential rare plant habitat proposed for disturbance In order to avold disturbance to rare plants or other unique vegetation.

3. Revegetation of all disturbed areas with native plant species of benefit to wildiffe.

4. Site-specific monitoring at each power plant for the effects of boron on vegetation.

5. Occasional spot monitoring to detect potential cumulative vegetation effects from chrontc low-level boron exposure and to determine if acld rain impacts are occurring.

Wildife--There is a potential for significant cumulative impacts to wildife In The KGRA. Habitat loss of 2,790 acres or greater is expected and the remalning habitat will be scattered through the developed area. Wildife in these areas will be subjected to the surrounding secondary disturbances. All 
habitat losses reduce the wildlife carrying capacity of an area, but the point at which such declines can be called "significant" is arbitrary, especially considering the lack of existing baseline data.

Basic Information such as population densities and species diversities are unknown for most of the potential 100 square mile vapor-dominated field. Without the field data needed to evaluate the effects of such factors as increased access, patchiness, and edge, it is not possible to decide how detrimental expanded geothermal development will be. Long-term effects are likely to include increases in disturbance-tolerant wildlife populations, decreases in disturbance-intolerant wildlife populations, and shifts in overall species diversity and distribution. Development which destroys critical hab1tat, such as meadows, springs, seeps, and riparian areas, will undoubtedly have adverse impacts on wildlife. Losses of breeding and foraging areas for protected wildife species will pose a threat to the continued success of those species in the geothermal area.

The accumulation of mercury and arsenic in terrestrial and aquatic food chains has not been assessed to date because of insufficient baseline data. Because background levels of arsenic and mercury in The Geysers are likely to be elevated due to natural geo-hydrothermal activity, it may be difficult to meaningfully assess the significance of very low levels of trace metal emissions.

The CEC staff recommends the following to reduce adverse impacts to wildlife:

1. Coordinate with various agencies and the Federal Pacific Coast American Peregrine Falcon Recovery Team to identify and monitor potential eyries and critical foraging locations and to identify mitigation measures and 
support their efforts to determine transmission line impacts on peregrine mortality.

2. Participate in interagency studies to identify eyries and foraging habitat critical to the golden eagle population in The Geysers areas and to Identify mitigation measures adequate to reduce geothermal development impacts on this species to acceptable levels.

3. Baseline studies and monitoring be conducted to determine habitats used by the fully protected ringtall. Avold development in ripartan zones, particularly riparian areas known to support ringtall populations.

4. Minimize the area of wildlife disturbance and enhance habitat surrounding disturbed areas to help offset wildlife losses.

5. Monitor the effectiveness of implemented wildife mitigation programs in order to determine those which benefit the greatest number of wildlife species.

6. Utilize off-site mitigation, enhancement, and compensation as necessary to preserve unique and representative habitats.

7. Develop monitoring programs to assess the potential accumulation of toxic trace elements in wildiffe food chains.

Aquatic Blota--A direct consequence of vegetation destruction in the KGRA is accelerated soil erosion and subsequent sediment loading of some streams located in watersheds undergoing geothermal development. This is a potentially significant problem, which will rapidly escalate as road density Increases and power plant construction continues. Given the topographic, 
hydrologic, and geologic features of the KGRA, any further development will incrementally increase naturally high erosion rates. Existing construction has triggered landslides and slumping in many areas which further disrupts vegetation and accelerates erosion.

Detrimental impacts to game fish populations caused by increased sedimentaton have been documented only in the case of Alder Creek. However, sediment loading of streams in Putah, Kelsey, and B1g Sulphur Creek drainages will Increase as geothermal development intensifies. If full geothermal development is unmitigated, it is highly likely that game fish populations in these drainages will be adversely impacted.

Other impacts of uncertain long-term significance include accidental dumping or spilling of toxic chemicals and increased water diversion for purposes of injection into the steam reservoir. Spllls are more $11 k e l y$ to be short term In nature; however, they are unpredictable, will continue to occur in the future, and can have significant effects. The significance of biological impacts caused by water diversion projects or creation of small impoundments can have potentially significant effects on game fish populations, but quantitative impacts cannot be determined at this time.

In order to reduce potential significant adverse impacts on aquatic resources, staff recommends:

1. Development of effective controls for site-specific erosion and the design of facilities to contain spills of toxic substances.

2. Avoidance of development on the most sensitive areas of highly erodable soils. 
3. Early review of all geotherma1-related development to reduce unnecessary ground disturbance and to encourage implementation of erosion control measures.

4. Continue working with developers to minimize potential hazards from transport, storage, and disposal of toxic substances.

5. Development of and CEC participation in a regional aquatic resources monttoring program.

CONCLUSIONS

Development and use of the geothermal steam resource In The Geysers KGRA is characterized by the incremental division and conversion of a rural area with considerable.biological resource values into a reglonal industrial development. Constrained by the nature of the steam resource, power plants average only 97 MW In capacity and must be located within approximately 1 mile of their supply wells. Development of the resource thus takes on a landintensive nature, with power plants and support facilities covering hundreds and potentially thousands of acres, leaving none of the remaining area far from development.

Vegetation loss, destruction of wlldlfe habitat, and accelerated stream sedimentation are the most significant existing and long-term impacts associated with geothermal development. Discussion of these Impacts has been limited to a 20-year period and to an area which potentially covers 100 square miles. Geothermal development and Its associated impacts could conceivably last much longer than the 30-year econonic lifetime of power plants. However, the lifetime of the steam resource under different exploitation scenarios is unknown, 
effectively precluding long-range resource planning and impact forecasting. And yet, the long-term consequences of geothermal development for biological resources must be considered now, rather than after the resource has been exhausted and power plants decommissioned. Accurate steam reservolr assessment (e.g., using computer models*) coupled with regional blological resource planning and assessment can provide a useful framework by which future geothermal development can be expanded in an economically. and biologically sound manner.

This report has identified the potential cumulative blological resource Impacts which may result from full development of the steam-dominated portion of The Geysers-Calistoga KGRA. It also has described actions proposed by staff to avoid or mitigate such impacts. Staff recognizes the need to develop blological resource protection policies and mitigation measures which can be used cooperatively by all planning and regulatory bodies (utllities, developers, counties, state, and federal) involved in The Geysers geothermal resource development. As a precursor to establishing such policies and mitigation measures, CEC staff will hold technical workshops to review the biological resource mitigation programs. The California Energy Commission will be holding hearings during 1981-82 to recelve public comments on these staff-proposed policies and programs. The goal of the hearings is to adopt resource protection policies and mitigation programs that will adequately protect biological resources and facilitate geothermal energy development in The Geysers •

\footnotetext{
*A computer model of the vapor dominated Larderello, Italy, geothermal system is considered feasible and is now being developed in Pisa, Larderello, and Berkeley (Weres, 1978).
} 
American Assoclation of Petroleum Geologists, 1978. Fleld Trip Guldebook Castle Steam Field, Great Valley Sequence. 53rd Annual Meeting, Pacific Sections AAPG, SEPM, SEG.

Angwin, M., and W. Toy. 1979. As sessment of $\mathrm{H}_{2} \mathrm{~S}$ Control Technologies for Geothermal Power Plants. Acurex Final Report 79-345.

Atlantis Scientific. 1975. Environmental Impact Report, Castle Rock Springs Geothermal Steam Area: Burmah 011 and Gas Company. Lake County, CA.

Atlantis Scientific. 1976. Environmental Impact Report, Geothermal Steam Area, Lake County, California. Lake County, CA. July 15, 1976

Axtmann, R.C. 1975. Environmental Impact of a geothermal power plant. Sclence 187:795.

Bacon, C.F., Amimoto, P.Y., Sherburne, R.W., Slosson, J.E. 1976. Engineering Geology of The Geysers Geothermal Resources Area, Lake, Mendocino and Sonoma Counties, California. California Division of Mines and Geology Special Report 122.

Bennett, J.P., Resh, H.M., and Runecke1s, V.C. 1974. Apparent stimulations of plant growth by air pollutants: Can.J. Bot. 52:35-41.

California Department of Conservation. 1971. Environmental Impact of Urbanization on Foothill and Mountainous Lands of California. State of Cal1fornia, the Resources Agency, Department of Conservation, Division of Soll Conservation, Sacramento, CA. 70 pages.

California Department of Fish and Game. 1977. Status Designations of Cal1fornia Animals. Nongame Wildlife Investigations, Sacramento, CA.

California Department of Fish and Game. 1978. Notification of Removal of Materials and/or Alteration of Lake, R1ver, or Streambed Bottom or Margin. No. III-1222-78. September 26, 1978.

Callfornia Department of Water Resources. 1978. Department of Water Resources Notice of Intention. Bottlerock Power Plant.

California Department of Water Resources. 1979. Department of Water Resources Notice of Intention, South Geysers Power Plant:. Sacramento, CA.

California Division of Forestry. 1972. Wildland Solls, Vegetation and Activities Affecting Water Quality. Report for State Water Resources Control Board, Sacramento, CA.

California Energy Commission. 1979a. Final Report on the DWR Notice of Intention to File an Application for Certification for Bottlerock Power Plant. California Energy Commission, Sacramento, CA. May 1979. 
California Energy Commission. 1979b. Final Report on the Pacific Gas and Electric Company's Notice of Intention to Seek Certification for Geysers Unit 16. California Energy Commission, Sacramento, CA. July 1979.

California Energy Commission. 1979c. Pacific Gas and Electric Company. Geysers 17 Geothermal Power Plant, Sonoma County, CA. Environmental Impact Report. California Energy Commission, Sacramento, CA.

Callfornia Energy Commission. 1979d. Pacific Gas and Electric Company, Geysers Unit 18 Geothermal Power Plant, Sonoma Co., CA. Draft Environmental Impact Report. California Energy Commission, Sacramento, CA. December 1979.

California Energy Commission. 1981. Status of Geothermal Electricity Projects. Staff report P700-81-013. Sacramento, CA.

California office of Planning and Research. 1981. CEQA: The California Environmental Quality Act, Laws and Guidelines. State of California, Sacramento.

COMARC Design Systems. 1975. The Geysers KGRA: A Vegetation and Wild1ife Habitat Mapping, prepared by Comarc Design Systems and Envicom Corp. under contract to Pacific Gas and Electric Company and Union 011 Company of California and in cooperation with the California Department of Fish and Game and U.S. Fish and Wildlife Service, San Francisco, CA.

Crow, N.B. 1978. An Env1ronmental Overview of Geothermal Development: The Geysers-Calistoga KGRA. Volume 4. Environmental Geology. Lawrence Livermore Laboratory, Livermore, CA.

Dykstra, H. 1981. Reservior Assessment of The Geysers Field-Reservoir Engineering. Unpublished report to the California Division of 011 and Gas, Sacramento, CA.

Eaton, M. K. 1981. Wildlife Habitat Loss Due to Geothermal Development in The Geysers-Calistoga Known Geothermal Resources Area. . Report No. 420-80.2. Pacific Gas and Electric Company Department of Engineering Research, San Ramon, CA.

Ebbeson, H. 1978. Acid rain study. In: Geothermal Environmental Seminar-'78. May $9-11,1978$. Sacramento, CA. F.L. Tucker and L.R. Tanner, eds. Lake County Printing, Clear Lake Oaks, CA.

ECOVIEW. 1975a. The Geothermal Leasehold of Union 011 Company at The Geysers, Sonoma County, CA. February 1975.

ECOVIEW. 1975b. A Draft EIR for Burmah 011 and Gas Company, Wildhorse Leasehold (Part I) on the Squaw Creek Drainage in N.E. Sonoma and Small Parts of Mendocino and Lake Counties, CA.

ECOVIEW. 1976a. A Draft Environmental Impact Report for Shell 0il Company United States Geothermal Leasehold Drili Site E, Lake County, CA. 
ECOVIEW. 1976b. A Draft EIR for Shell Oil Company, USGR Lease Two (CA-950) Drill Site G, Sonoma County, CA, Napa County, CA.

ECOVIEW. 1978. Draft EIR. Thermogentcs, Inc. Klau Mine Leasehold Expansion Project, Lake County, CA.

Ehrllch, P.R., Ehrlich, A.H., Holdren, J.P. 1977. Ecosclence. W.H. Freeman and Company. 1,052 pp.

Enderson, J.H., and Kirven, M.N. 1980. Final Report, Peregrine Falcon Foraging Study in The Geysers-Callstoga Known Geothermal Resource Area, Sonoma County, California, 1979. In: Final Report Peregrine Falcon Study. February 1, 1980. Geothermal Research Information and Planning Services Commission.

Fontes, R.A., L. Joyce. 1978. Air Quality as the Limiting Factor on Development of The Geysers Geothermal Resources. Cailfornia Energy Commission, Sacramento, CA.

GeothermEx, Inc. 1980. Evaluation of the Potential for generation of electricity, Geothermal Lease CA-1862, Sonoma and Lake Counties, California. Prepared for Sacramento Municipal Utility District, Sacramento, California a by GeothermEx, Inc., Berkeley, CA.

GRIPS Commission. 1980. Final Report, Peregrine Falcon Study. Geothermal Research Information and Planning Services (GRIPS)--A California Joint Powers Agency, Napa, CA.

Isherwood, W. 1977. Geothermal reservoir interpretation from change in gravity. In: Proc.3rd Workshop Geoth. Res. Eng. P. Kruger, H.J. Ramey, Jr., eds. December 14-16, 1977. Stanford Geothermal Program, Stanford University, Stanford, CA.

Reezer, G.S. 1976. Testimony submitted before the California Energy Commission in the matter of Pacific Gas and Electric Company's Notice of Intention, Combined-Cycle Plant. Docket No. 76-NOI-3. California Energy Commission, Sacramento, CA.

Kirven, M.N. 1980. Phase I Fleld Study. Peregrine Falcons of Mount St. Helena in The Geysers-Calistoga Known Geothermal Resource Area. U.S. Dept. of Energy Grant No. ET-78-G-03-2068. Submitted to Geothermal Resource Impact Project Study Jo1nt Powers Agency, Santa Rosa, CA.

Koch, D. and Brody A. 1981. Status of the Ringtall (Bassariscus astutus) In the Geysers-Calistoga known Geothermal Resource Area Contract 700-80-030, California Energy Commission, Sacramento, CA.

Koranda, J. 1980. Interim Report: Studies of Boron Deposition Near Geothermal Power Plants. (LImited external distribution). Lawrence Livermore Laboratory, Livermore, CA. 
Leitner, P. 1978a. An Environmental Overview of Geothermal Development: The Geysers-Callstoga KGRA. Volume 3: Noise. Lawrence Livermore Laboratory, Livermore, CA.

Leitner, P. 1978b. An Environmental Overview of Geothermal Development: The Geysers-Calistoga KGRA. Volume 5: Ecosystem Quality. Lawrence Livermore Laboratory, Livermore, CA.

Lipman, S.C., Strobel, C.J., Gulati, M.S. 1977. Reservoir performance of The Geysers Field. In: Proceedings of the Larderello Workshop in Geothermal Resource Assessment and Reservoir Engineering. September 12-16, 1977.

Lofgren, B.E. 1978. Monitoring Crustal Deformation in The Geysers-Clear Lake Geothermal Area. USGS Open-file Report 78-597, Sacramento, CA.

Malloch, B.S., Eaton, M.K., and Crane, N.L. 1979. Assessment of Vegetation Stress and Damage Near The Geysers Power Plant Units. Pacific Gas and Electric Company, Department of Engineering Research Report 420-79.3, San Ramon, CA.

Martin, A.C., Zim, H.S., Nelson, A.L. 1951. American Wildlife and Plants. Dover Publications, Inc., NY. ix +500 pp.

McLaughlin, R.J. and Stanley, W.D. 1975. Pre-Tertiary Geology and Structural Control of Geothermal Resources, The Geysers Steam Field, California. Proc. from 2nd UN Symposium on the Development and Use of Geothermal Resources Vol. I. San Francisco, CA, May 1975.

Meneghin. G.R., Hall, D.J., Malloch, B.S., Choteau, N.C. 1978. The Geysers 18 Leasehold and Site Specific Studies Terrestrial Ecology. Pacific Gas and Electric Company, Department of Engineering Research Report 411-78.194. San Ramon, CA.

Northern California Power Agency. 1978. Notice of Intention for the NCPA Geothermal Project No. 2 (NCPA/Shell Project). NCPA, Santa Clara, CA.

Northern California Power Agency. 1979. Notice of Intention for the NCPA 66 MW Geothermal Power Plant. Santa Clara, CA.

Ornduff, R. 1976. Introduction to Calffornia Plant Life. University of California Press. Berkeley, CA.

Pacific Gas and Electric Company. 1977a. Environmental Data Statement, Geysers Unit 17. San Francisco, CA.

Pacific Gas and Electric Company. 1977b. The Geysers Known Geothermal Resource Area Wildlife Study. The Distribution and Abundance of Wildlife Populations in Relation to Geothermal Development: Interim Report. San Ramon, CA.

Pacific Gas and Electric Company. 1978. Notice of Intention, Geysers Unit 17. San Francisco, CA.

Pacific Gas and Electric Company. 1979a. Application for Certification, Geysers Unit 17. San Francisco, CA. 
Pacific Gas and Electric Company. 1979b. Application for Certification, Geysers Unit 18. San Francisco, CA.

Pacific Gas and Electric Company. 1979c. San Francisco, CA. Letter to R. Therkelsen, California Energy Commission, Sacramento, CA.

PImentel, K.D. 1978. An Environmental Overview of Geothermal Development: The Geysers-Calistoga KGRA. Volume 6: Water Quality. Lawrence Liverwore Laboratories, LIvermore, CA.

Pimentel, K.D. 1978. Lawrence Livermore Laboratory, Livermore, California, letter to L. A. Enriquez. Pacific Gas and Electric Company, San Ramon, CA. November 17,1978 .

Price, D.G. 1975. KGRA Fishery Investigations. PGandE Co. Department of Engineering Research Report. 7784-75. San Ramon, CA.

Price, D.G. 1976a. An Inventory of F1shery Resources in the Kelsey Creek Drainage. The Geysers KGRA Fishery Investigations. PGandE Co. Dept. of Engineering Research. Report 7784.6-76. San Ramon, CA.

Price, D.G. 1976b. An Inventory of Fishery Resources in the Cole Creek Drainage. The Geysers KGRA Fishery Investigations. PGandE Co. Dept. of Engineering Research. Report 7784.6-76. San Ramon, CA.

Price, D.G. 1977a. An Investigation of Unique Water Quality Conditions in The Big Sulphur Creek Watershed Related to Natural Geothermal Activity, Streamflow, and Geothermal Development. PGandE Co. Department of Engineering Research. Report 420-77.1. San Ramon, CA.

Price, D.G. 1977b. Protecting Fishery Resources During Geothermal Development. Ecosystem Quality Workshop, October 25-27, 1977. Pacific Gas and Electric Company, San Ramon, CA.

Price, D.G., Geary, R.E., and Longenecher, D.R. 1980. Upper Putah Creek Monitoring Studies: Fishery Resources, Stream Sedimentation and Water Temperature Characteristics. PGandE Co. Dept. of Engineering Research. Report 420-80.94. San Ramon, CA.

Price, D.G. and Griffin, D.P. 1975. An Evaluation of Stream Water Quality Monitoring Data Collected from May 1968 through May 1975 at the Geysers and Its Implications to the Blological, Chemical, and Physical Environment. PGandE Co. Department of Engineering Research. Report 7784.2.-75. San Ramon, CA.

Price, D.G. and Kublcek, P.F. 1975. An Inventory of Fishery Resources on the Upper Putah Creek Drainage. The Geysers KGRA Fishery Investigation. PGandE Co. Department of Englneering Research. Report 7784.3-75. San Ramon, CA.

Ramey, H.J., Jr. Testimony before the California Energy Commission in relation to PGandE Geysers Unit 16 lotice of Intention. December 8, 1978. Sacramento, $\mathrm{CA}$. 
Reed, J.J., and Campbell, G.E. 1975. Environmental impact of development in The Geysers geothermal field, USA. In: Proc. 2nd U.N. Symposium on the Development and Use of Geothermal Resources. ed. Lawrence Berkeley Laboratory. pp. 1399-1410.

Rosen L.C., and Molenkamp, C.R. 1978. Air Quality, An Environmental Overview of Geothermal Development: The Geysers-Calistoga KGRA. Volume 2.

Stager, K.E. 1976. Report of Survey of the Status of the Peregrine Falcon in the Vicinity of Geysers Unit 13. Pacific Gas and Electric Company, San Ramon, CA.

Stanford Research Institute, International. 1977a. Consultant Report on Environmental Analysis for Geothermal Energy Development in The Geysers Region. Volume II. Master Environmental Assessment. Menlo Park, CA.

Stanford Research Institute, International. 1977b. Environmental Analysis for Geothermal Energy Development in The Geysers Region--Executive Summary. Prepared for the Californla Energy Commission. SRI, Menlo Park, CA.

Sacramento Municipal Utility District. 1980. Application for Certification. SMUDGEO 1. Sacramento, CA.

State of California. 1978. Guidelines for Implementation of the California Environmental Quality Act. California Administrative Code, title 14 division 6, chapter 3. Secretary of State, Sacramento, CA.

Steele, J.A. 1977a. Streambed Sedimentation in Drainages of the Clear LakeGeysers KGRA. Department of Fish and Game, Environmental Services, Region 3, Yountville, CA.

Steele, J.A. 1977b. Effects of Geothermal Development on Blood Physiology of Salmonids. California Department of Fish and Game, Environmental Services, Region 3, Yountville, CA.

Stockton, D. June 1979. Personal communication. Division of $0 i 1$ and Gas. Sacramento, CA.

Suter, G.W. 1978. Geothermal Development and Wildlife Behavior, Trans. Geo. Res. Council. pp. 627-629.

Temple, P.J., and Linzon, S.N. 1976. Boron as a phtotoxic air pollutant. J. Air Pollut. Control Assoc. 26(5):498-499.

Temple, P.J., and Smith, M.L. 1978. Fluoride and boron effects on vegetation in the vicinity of a flberglass plant. Water, Air, and Soil Pollution. $10(2): 163$.

Thompson, C.R., and Kats, G. 1978. Effects of Continuous $\mathrm{H}_{2} \mathrm{~S}$ Fumigation on Crop and Forest Plants. Env. Sce. Tech. 2(5):550-553.

Thompson, C.R. 1978. Behavior of $\mathrm{H}_{2} \mathrm{~S}$ in the atmosphere and 1 ts effects on vegetation. Testimony for the State Geothermal Task Force, Apri1 14 $15,1977$. 
United States Environmental Protection Agency. 1977. Western Energy Resources and the Environment: Geothermal Energy. Prepared by Resource Planning Assoc., Inc. For Office of Research and Development, Washington, DC.

United States Geological Survey. 1979. Assessment of Geothermal Resources of the United States-1978 (Geological Survey Circular 790).

United States Fish and Wildlife Service. 1978. Effects of Geothermal Energy Development on Fish and Wildilfe. Blological Services Program, United States Department of the Interior.

VTN Consolidated, Inc. 1976. Draft EIR, Thurston Lake Exploratory Project, prepared for Lake County Planning Department. Lake County, CA.

Weinberg, C.J. 1978. Environmental Aspects of Geysers Geothermal Operations. Pacific Gas and Electric Company, San Francisco, CA.

Weres, 0. 1978. The dynamics of steam producting geothermal reservoirs. In: Geothermal Environmental Seminar -78. May 9-11, 1978, sponsored by Environmental Systems and Services, held in Kelseyville, CA and Lake County Air Pollution Control District, Lake County, CA. Sacramento, CA.

Winner, W.E. 1981. The effect of $\mathrm{SO}_{2}$ on photosynthesis and stomatal behavior of Mediterranean-Climate shrubs. In: Components of Productivity of Mediterranean Regions--Basic and Applied Aspects. Margaris, N.S., and H. A. Monney (eds). W. Junk Publ., The Hague. 


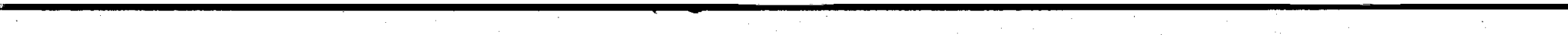




\section{APPENDICES}





\section{CONTENTS}

Page

Appendix A Plant Communities of the KGRA and Their

Characteristic Species...........

Appendix B Rare and Endangered Vascular Plants of The

Geysers KGRA, Status, and Blooming Time ... 102

Appendix C Vertebrate Animals of The Geysers KGRA . . . . 132

Appendix D Listing of Pollution Incidents at The

Geysers Geothermal Field ......... 141 
Appendix A

PIANT COMMUNITIES OF THE KGRA

AND THETR CHARACTERISTIC SPECIES

$92 / 93$ 



\section{GRASSIAND \\ Introduced Species: \\ Soft chess \\ Ripgut \\ Red brome \\ Western cheatgrass \\ wild oats \\ Slender wldoats \\ Hairgrass \\ Foxtail fescue \\ Iittle quakinggrass \\ Dog-tail \\ Golden top \\ Filaree \\ Bur clover \\ Bull thistle \\ Napa thistle \\ Vernal Whitlow grass}

Native Species:

Popcorn flower.

Tricolored gilia

Blue-field gilia

Valparaiso clover

Indian clover

Sour clover

Common linanthus

Yellow owl's clover

Napa cryptantha

Fringe pod

Dwarf athysanus

clarkia
Bromus mollis

Bromus diandrus

Bromus mubens

Bromus tectorum

Avena fatua

Avena barbata

Aira caryophyllea

Festuca megalura

Briza minor

Cynosurus echinatus

Lamarckia aurea

Erodium botrys, E. cicutarium,

Medicago polymorpha

Cirsium vulgare

Centaurea melitensis

Draba verna

Plagiobothrys nothofulvus

Gilia tricolor

Gilia capitata

Trifolium microdon

Trifolium dichotomum

Trifolium fucatum

Iinanthus androsaceus

Orthocarpus attenuatus

Cryptantha hispidula

Thysanocarpus laciniatus

Athysanus pusillus

Clarkia gracilis 
OAK SAVANNAH

Big leaf maple

Blue oak

Oregon oak

Califormia black oak

Valley oak

Digger pine

Elderberry

Hajr grass

Whitlow grass

Wild oats

Small quaking grass

Brome grasses

Dogtail grass

Foxtails

Fescue grasses

Tall stephanomeria
Acer macrophyllum

Quercus jouglasii

Quercus garryana

Quercus kelloggii

Quercus lobata

Pinus sabiniana

Sambucus mexicana

Aira caryophyllea

Athysanus pusillus

Avena barbata, A. fatua

Briza minor

Bromus diandrus, B. inermis, B. molits

Cymosurus echinatus

Festuce dertonensis, F. erects F. Idahoensis

Stephanomeria virgata

\section{OAK WOODLAND}

Valley oak

Interior live oak

Garry oak

Canyon oak

Buckeye

Yellow pine

Digger pine

Douglas Fir

Madrone

Big-leaf maple

California bay

Yerba santa

California coffeeberry

Poison oak

Gum plant

Bird's foot fern
Quercus lobata

Quercus wislizenii

Quercus garryana

Quercus chrysolepis

Aesculus califormica

Pinus ponderosa

Pinus sabiniana

Pseudotsuga menziesii

Arbutus menziesii

Acer macrophyllum

Umbellularia califormica

Eriodictyon californicum

Rhamnus californica

Rhus diversiloba

Grindelia hirsutula

Pellaea mucronata 
Bracken fern

\section{CHAPARRAI}

Mixed Chaparral

Chamise

Manzanitas

Ceanothus

Mountain mahogany

- Yerba santa

California fescue

Silk tassel

Small willow herb

Toyon

Gold wire

Iomatium

Mountain monardella

Chaparral pea

Scrub oak

Dwarf interior live oak

Coffeeberry

Poison oak

Squaw bush

Canyon gooseberry

Gooseberry

California bay

Star Iily

Serpentine Chaparral

Chamise

Whiteleaf manzanita

Jepsons ceanothus
Pteridium aquilinum

Adenostoma fasciculatum

Arctost aphylos-A. canescens,

A. glandulosa, A. manzanita,

A. stanfordiana, A. viscida

Ceanothus cuneatus, C. foliosus

Cercocarpus betulojies

Eriodictyon californicum

Festuca californica

Garrya elliptica

Gayophytum nuttalli

Heteromeles erbutifolia

Hypericum concinnum

Iomatium marginatum

Monardella odoratissima

ssp. pinetorum

Plckeringia montana

Quercus dumosa

Quercus wislizinil var. frustescens

Rhamnus califormica

Rhus (Toxicodendron) diversilobum

Rhus trilobata

Ribes menziesi1 var. leptosmum

Ribes quercetorum

Umbellularia californica

Zigadenus fremontit

Adenostoma fasciculatum

Arctostaphylos viscida

Ceanothus jepsonii. 
Sargent cypress

Willow herb

Cliffrake

Bird's foot fern

Digger pine

Leather oak

Chamise Chaparral

Chamise

Buckbrush

Wavyleaf ceanothus

Mountain mahogany

Horehound

Green monaradella

Virgate phacelia

Star lily

-

MIXXD EVERGREFN FOREST

Bigleaf maple

Buckeye

Madrone

Hoary manzanita,

Deer bush

California fescue

Bluegrass

Douglas fir

Bracken fern

Canyon oak

Scrub oak

Oregon oak

California black oak

California coffeeberry
Cupressus sargenti1

Epilobium minutum

Onychium densum

Pellaea mucronata

Pinus sabiniana

Quercus durata

Adenostoma fasciculatum

Ceanothus cuneatus

Ceanothus foliosus

Cercocarpus betuloides

Marrubium vulgare

Monardella viridis

Phacelia heterophylla

Zigadenus fremontii

Acer macrophyllum

Aesculus californica

Arbutus menziesii

Arctostaphylos canescens

Ceanothus integerrimus

Festuca californica

Poa sp.

Pseudotsuga menziesii

Pteridium gquilinum var. lanuginosum

Quercus chrysolepis

Quercus dumosa

Quercus garryana

Quercus kelloggii

Rhamnus californica 
Poison oak

Califormia rose

California nutmeg

California bay

YEILOW PINE FOREST

Chamise

Manzanita

Deer brush

Mountain mahogany

Dogwood

Mountain ash

Bedstraw

Sugar pine

Ponderosa pine

Douglas $f$ ir

Canyon oak

Black oak

Canyon live oak

Coffeeberry

KNOBCOIE PINE FOREST

Chamise

Manzanita

California lilac

silk-tassel bush

Knobcone pine

Leather oak

Interior live oak

DOUGIAS FIR FOREST

Douglas fir

Black oak
Rhus (=Toxicodendron) diversilobum

Rosa californica

Torreya ralifornica

Umbellularia califormica

Adenostoma fasciculatum

Arctostaphylos spp.

Ceanothus integerrimus

Cercocarpus betuloides

Cornus sp.

Fraxinus dipetala

Galium californicum

Pinus lambertiana

Pinus ponderosa

Pseudotsuga menziesii

Quercus hhrysolepis

Quercus kelloggi1

Quercus wislizeni1

Rhamnus californica

Adenostoma fasciculatum

Arctostaphylos spp.

Ceanothus spp.

Garrya elliptica

Pinus sttenuata

Quercus durata (on serpentine soils)

Quercus wislizenif

Pseudotsuga menziesii

Quercus kelloggii 
Canyon oak

Madrone

Dogwood

Big leaf maple

Califormia bay

Giant chinquapin

Snowberry

Deer brush

Coffeeberry

Shrub interior live oak

Gooseberry

Bracken fern

Iupines

Leafless wintergreen

Sugarstick saprophyte

Yellow-flowered groundsel

White-flowered hawkweed
Quercus chrysolepis

Arbutus menziesii

Cornus nuttallii

Acer macrophyllum

Umbellularia califormica

Castanopsis chrysophylla

Symphoricarpos albus

Ceanothus integerrimus

Rhamnus californica

Quercus wislizenii var. frutescens

Ribes spp.

Pteridium aquilinum var lanuginosum

Iupinue latifolius,

L. andersonii

Pyrola aphylla

Allotropa virgata

- Senecio aronicoides

Hieracium albiflorum

\title{
CYPRESS FOREST
}

Chamise

Hoary manzanita

Parry manzanita

Macnab cypress

Yerba santa

Bedstraw

Interior live oak

Knobcone pine

\section{RIPARIAN}

White alder

Alnus rhombifolia

Mugwort

\author{
Adenostoma fasciculatum \\ Arctostaphylos canescens \\ Arctostaphylos manzanita \\ Cupressus macnabiana \\ Eriodictyon californicum \\ Galium andrewsii \\ Quercus wislizenii \\ Pinus attenuata
}

Artemisia vulgaris 
Sedge

Perennial rye grass

Horsetail

Rush

Wood rush

Pellitory

Californie polypody

Rabbitsfoot grass

Callfornia fern

Western sword fern

Fremont cottonwood

Willows

Squirreltail

Western verbena

Grape

AQUATIC VEGETATION

Ponds

Cattails

Common smartweed

Duckweed

Marsh pennywort

Curly dock

Wood rush

Blue eyed grass

Slender rush

Sedge
Cyperus arlstatus, C. eragrost1s

Elymus glaucus, Eo triticoides

Equisetum arvense

Juncus tenuis, var. congestus

Lazula subsessilis

Parietaria pensylvanica

Polypodium californicum

Polypogon monspeliensis

Polystichum californicum

Polystichum munitum

Populus fremontii

Salix laevigata, S. lasiandra

Sitanion hystrix

Verbena lastostachys var.

septentrionalis

Vitis californice

Typha latifolia

Polygonum hydropiper

Lemna minima

Hydrocotyle ranunculoides

Rumex crispus

Luzula parviflora

Sisyrinchium bellum

Juncus tenius

Carex dudlevi 
Springs

Yellow willow

Horsetails

Pinnate-leaved hosakia

Yellow monkey-flower.

Panicled willow herb

Redtops

Junegrass

Sweet vernal grass

Bracken fern

Hot Springs

Yellow sedge bluestem

Centaury

Penicum gress

WEEDY VEGETATION

Athysanus

Foxtail chess

Centaury

Hairgrass

Rye grass

Rye grass

Turkey mullein

Filaree

Cranesbill

Dwarf flex

Bird's foot trefoil

Tall stephanomeria

Turpentine weed

Vetch

\section{Equisetum arvense}

Iotus pinnatus

Mimulus guttatus

Epilobium paniculatum

Agrostis ampla

Koelerie cristata

Anthoxanthum odoratum

Pteridium aquilinum var. lanuginosum

Andropogon virginicus

Centarium umbellatum

Panicum thermale

Athysanus pusillus -

Bromus mbens

Centaurium muehlenbergii

Deschampsia caespitosa

Elymus caput-medusae

Elymus glaucus

Eremocarpus setigerus

Erodium spp.

Geranium spp.

Hesperolinon sp.

Iotus spp.

Stephanomeria virgata

Trichostema laxun

Vicia spp.

SOURCE: S.R.I. 1977, Meneghin, et al. 1978, P.G\&E. 1978 
Append IX B

RARE AND ENDANGERED VASCULAR PLANTS

OF THE GEYSERS KGRA, STATUS, AND BLOOMING TIMES 
EE-23 RPS 
Table 1. Known Occurrence of Very Rare, Rare and

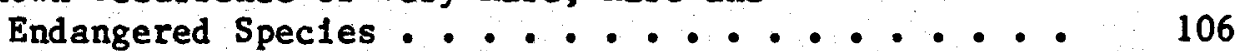

Table 2. Known Occurrence of Rare But Not Endangered Plants . $\quad 110$

Table 3.. Known Occurrence of Plants Rare In Cal Ifornla But Common El sewhere . . . . . . . . . 114

Table 4. Officlal Status of Very Rare, Rare and Endangered Plant Specles (CNPS List 2). ..........

Table 5. Official Status of Rare But Not Endangered Plants (CNPS List 3).................

Table 6. Official Status of Plants Rare in California But Common El sewhere ................

Table 7. Blooming Times of Rare Plants in the KGRA. . . . 126 References .......................... 
TABLE 1

RNOWN OCCURRENCE OF VERY RARE, RARE AND ENDANGERED PLANT SPECIES

Habitat/Species

County

Lake Napa Sonoma Mendocino

Known Occurrence

Within the KGRA

SPECIES ON WET SITES

Bl ennosperma baker1

Heiser

$\mathrm{X}$

No

Carex albida Balley

$\mathrm{X}$

No

*Dicanthel ium acuminatum

(SW) Gould \& Clark

var. acuminatum

$\mathrm{x}$

$\mathrm{X}$

Yes

Gratiola heterosepala

Mason and Bacig.

$\mathrm{X}$

Yes

Lasthenta burke1

(Greene) Greene

$\mathrm{X}$

$x$

$\mathrm{x}$

Yes

Lasthenia conjugens

Greene

$\mathrm{X}$

$\mathrm{X}$

Yes

Legenere 11mosa (Greene)

McVaugh

$\mathrm{X} \quad \mathrm{X} \quad \mathrm{X}$

Yes

Navarretia pauciflora

Mason

$x$

Yes

Navarretia pl leantha

Mason

$x$

Yes

Orcuttia tenuis Hitchc.

$\mathrm{x}$

$\mathbf{x}$

Yes

Parvisedum lelocarpum

(H.K. Sharsm.)

Clausen

$\mathrm{X}$

Yes

Perideridia galrdneri

(H.\&A.) Math. ssp. galrdner1

X

Yes

*=Panicum thermale Bolander sp. emend. Schmol1. Taxonomic changes are acknowledged; species remalns listed pending confirmation of its rarity status. 
County

Habitat/Species

Plagiobothrys strictus

(Greene) Jtn.

Poa napens1s Beetle

Pogogyne douglasil Benth ssp. parviflora (Benth.)

J.T. Howel1

Sidalcea oregana (Nutt.)

Gray. ssp. hydrophila

(Hel ler) Hitche.
Lake Napa Sonoma Mendocino

X $\quad \mathrm{X}$

$x$

$\mathrm{x}$

$\mathrm{x}$

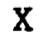

Yes

X $\quad \mathrm{X}$

Yes

SPECIES ON DRY OR MOIST SITES

(nonserpentine)

Astragalus clarlanus

Jeps.

$\mathrm{X} \quad \mathrm{X}$

Yes

Brodiaea coronaria (Salisb.)

Engler ssp. rosea (Greene)

Niehaus

$\mathrm{X}$

Ceanothus confusus

Howell

X $\mathrm{X} \quad \mathrm{X}$

Yes

Ceanothus divergens

Parry

X $\quad \mathrm{X} \quad \mathrm{X}$

Yes

Eriastrum brandegeae

Mason

$x$

Yes

Eryngium constance1

Sheikh, Ined.

Yes

Hesperol inon drymarioides

(Curran) Small

$\mathrm{x}$

No

Parvisedum lelocarpum

(H.K. Sharsm.) Clausen

Tracyina rostrata Blake $X$

$x$

Yes

No

SPECIES ON SERPENTINE SITES

Antirrhinum subcordatum

Gray 
Cordylanthus tenuis Gray

ssp. cap11laris

(Pennel1) Chuang and

Heckard

$\mathrm{X}$

Yes

Erlogonum nervulosum

(Stokes) Reveal

X

$\mathbf{X}$

Yes

Hellanthus exilis Gray

Hesperolinon adenophy1lum (Gray) Smal1

Hesperolinon brewer 1 (Gray) Sma11

Hesperolinon didymocarpum H.K. Sharsm.

Streptanthus brachiatus Hoffm.

Streptanthus morrisoni1 complex Hoffm.
$\mathrm{X}$

$\mathbf{X}$

Yes

X $\quad \mathrm{X}$

$\mathrm{X}$

Yes

Yes

$\mathrm{X}$

Yes

$\mathrm{x} \quad \mathrm{x} \quad \mathrm{x}$

Yes 


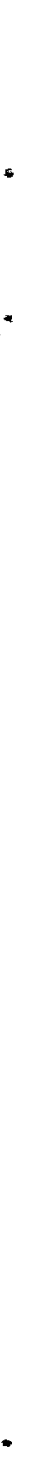

$\leftarrow$

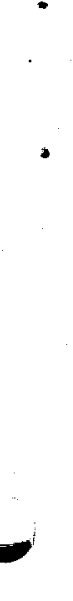


TABLE 2

RNOWN OCCURRENCE OF RARE BUT NOT ENDANGERED PLANTS*

County

Known Occurrence

Habitat/Species

Lake Napa Sonoma Mendocino

Within the KGRA

SPECIES ON WET SITES

Cuscuta howelliana

Rubtzoff

$\cdot \mathrm{X}$

Yes

Delphinium uliginosum

Curran

X $\quad \mathrm{X}$

Yes

Lepidium latipes Hook

$\mathrm{X}$

Yes

Ranunculus lobbil (Hiern.)

Gray

$\mathrm{X} \quad \mathrm{X} \quad \mathrm{x}$

Yes

SPECIES ON DRY OR MOIST SITES -

(nonserpentine)

Amsinckia lunaris Macbr. X X

Antirrhinum virga Eastw. .

Arabis modesta Roll.

Astragalus breweri Gray

X $\quad x \quad x$

Yes

Astragalus cleveland 1 Gray

X $\quad \mathrm{X}$

Yes

Calochortus pulchellus

Doug1 ex. Benth

$\mathrm{x} \quad \mathrm{x} \quad \mathrm{x}$

Yes

Calyptridium quadripetal um Wats

X $\quad \mathrm{X}$

Ceanothus purpureus Jeps.

$\mathrm{X}$

Yes

Coll1nsia greene1 Gray

$\mathrm{X} \quad \mathrm{x} \quad \mathrm{X}$

Yes

Erlogeron petrophilus (Greene)

$x \quad x \quad x$

$x$

Yes

Eriogonum caninum (Greene) Munz

$\mathrm{x} \quad \mathrm{x}: \mathrm{x}$

Yes 
Euphorbia ocellata Dur. \& Hilg. var. rattani1

Fritillaria pluriflora

Torrey ex Bentham

$\mathrm{x} \quad \mathrm{X}$

$\mathrm{x} \quad \mathrm{x}$

$x$

No

Lilium rubescens Wats.

Lomatium c1liolatum Jeps. var. hoover1 Math \& Const.

Lomatium repostum (Jeps.) Math.

Lupinus sericatus Kel.

Mimulus nudatus Curran ex. Greene

Monardella viridis Jeps. ssp. viridis

Pityopus californicus

(Eastw.) Copel.

Ribes victoris Greene

SPECIES ON SERPENTINE SITES

Asclepias solanoana Wood son$$
\text { X } \quad \mathrm{X}
$$

X $\quad \mathrm{X} \quad \mathrm{X}$

Yes

$\mathrm{X} \quad \mathrm{X}$

Yes

X $\quad \mathrm{x}$

Yes

Calamagrostis ophitidis

(Howe11) Nygren

Collomia diversifolia

Greene

Cryptantha hispidula

Greene ex. Brand

Fritillaria purdyi

Eastw.

Hesperol 1non adenophyllum (Gray) Smal 1
$\mathrm{X}$

$\mathrm{X}$

Yes

$\mathrm{X} \quad \mathrm{X}$

Yes

X X

Yes

X $\quad x$

Yes

Yes

Yes

X $x$

Yes

$\mathrm{X}$

$\mathrm{X}$

Yes 
Habitat/Species

Hesperolinon

blcarpellatum

(H.K. Sharsm.) H.K.

Sharms.

Navarettia jepsonil

Balley ex. Jeps.'

Nemacladus montanus Greene

Senecio cleveland11 Greene
County

Lake Napa Sonoma Mendocino
Known Occurrence

Within the RGRA $\mathrm{x} x \mathrm{x}$

X $\quad \mathrm{X}$

$\mathrm{X} \quad \mathrm{X} \quad \mathrm{X}$

$\mathrm{X} \cdot \mathrm{X}$
Yes

Yes

Yes

Yes

$112 / 113$ 

TABLE 3

KNOWN OCCURRENCE OF PLANTS RARE

IN CALIFORNIA BUT COMMON ELSEWHERE

Habitat/Species

SPECIES ON WET SITES

Calochortus uniflorus
County

Lake Napa Sonoma Mendocino
Known Occurrence

W1thin the KGRA 

TABLE 4

OFFICIAL STATUS OF VERY RARE, RARE

AND ENDANGERED PLANT SPECIES (CNPS LIST 2)

Rare P1ant Status

Habitat/Species

CNPS $^{1}$ R-E-V-D

USFWS $^{2}$

State $^{3}$

SPECIES ON WET SITES

Blennosperma bakeri

Helser

Carex albida Balley

$3-2-2-3$

1

*Dicanthel ium acuminatum

(SW) Gould \& Clark

var. acuminatum

Grat1ola heterosepala

Mason and Bacig.

Lasthenla burke1

(Greene) Greene

$3-3-2-2$

1

$3-2-1-3$

1

E

Lasthenia conjugens

Greene

$3-3-2-3$

1

E

$3-3-2-3$

1

E

Legenere 11mosa (Greene) McVaugh

Navarretia pauciflora

Mason

Navarret1a plieantha

Mason

$3-2-2-3$

1

Orcuttia tenuis Hitchc.

$3-3-2-3$

1

E

Parvisedum lelocarpum

(H.K. Sharsm.)

Clausen

$2-2-2-3$

1

Perlderldia galrdneri

(H.\&A.) Math. ssp.

$3-3-3-3$

1

$2-2-1-3$

$3-2-1-3$

E gairdner1

$2-2-2-3 \quad 1$

*=Panicum thermale Bolander sp. emend. Schmoll. Taxonomic changes are acknowledged; species remains listed pending confirmation of 1 ts rarity status. 
Rare Plant Status

Habitat/Species

Plagiobothrys strictus

(Greene) Jtn.

Poa napensis Beetle

Pogogyne douglasif Benth ssp. parviflora (Benth.)

J.T. Howe11

Sidalcea oregana (Nutt.)

Gray ssp. hydrophila

(Heller) Hitchc.

SPECIES ON DRY OR MOIST SITES

(nonserpentine)

Astragalus Clarianus

Jeps.

Brodiaea coronaria (Salisb.) Engler ssp. rosea (Greene) Niehaus

Ceanothus confusus Howe 11

Ceanothus divergens Parry

Erlastrum brandegeae Mason

Eryngium constancei Sheikh, ined.

Hesperolinon drymarioldes (Curran) Small

Parvisedum leiocarpum (H.K. Sharsm.) Clausen

Tracyina rostrata Blake

$$
\text { CNPS } 1 \text { R-E-V-D }
$$$$
3-2-2-3
$$

USFWS 2

state $^{3}$

$$
3-3-2-3
$$

$2-1-1-3$

\section{1}

1

2

$2-1-1-3$

2

$3-2-3-3$

1

$\begin{array}{ll}3-3-2-3 & 1\end{array}$

$3-2-1-3$

$2-1-1-3$

$3-2-2-3$

$3-1-1-3$

$2-1-1-3$

$2-2-2-3 \quad 1$

$3-1-1-3$

$\mathbf{T}$ 
Rare Plant Status

Habitat/Species

CNPS ${ }^{1} \mathrm{R}-\mathrm{E}-\mathrm{V}-\mathrm{D} \quad \mathrm{USFWS}^{2}$

State $^{3}$

SPECIES ON SERPENTINE SITES

\begin{tabular}{|c|c|c|}
\hline$\frac{\text { Antirrhinum subcordatum }}{\text { Gray }}$ & $2-2-2-3$ & 1 . \\
\hline $\begin{array}{l}\frac{\text { Cordylanthus }}{\text { ssp. cap1liaris }} \\
\text { (Pennel1) Chuang and } \\
\text { Heckard, comb. nov. Ined. }\end{array}$ & $2-2-1-3$ & 1 \\
\hline$\frac{\text { Erlogonum }}{\text { (Stokes) }} \frac{\text { nervulosum }}{\text { Reveal }}$ & $2-1-1-3$ & 2 \\
\hline$\frac{\text { Hellanthus }}{\text { Gray }}$ ex111s & $2-2-2-3$ & 2 \\
\hline$\frac{\text { Hesperolinon }}{\text { (Gray) Sma } 11}$ & $2-1-2-3$ & 1 \\
\hline$\frac{\text { Hesperolinon didymocarpum }}{\text { H.K. Sharsm. }}$ & $3-2-2-3$ & 1 \\
\hline$\frac{\text { Streptanthus }}{\text { Hoffm. }}$ & $3-2-1-3$ & 1 \\
\hline$\frac{\text { Streptanthus morrisonit }}{\text { complex. Hoffm. }}$ & $2-2-1-3$ & 1 \\
\hline
\end{tabular}



TABLE 5

OFFICIAL STATUS OF RARE BUT NOT

ENDANGERED PLANTS (CNPS LIST 3)

Rare Plant Status

Hab1tat/Species

CNPS $^{1}$ R-E-V-D

USFWS $^{2}$

State $^{3}$

SPECIES ON WET SITES

Cuscuta Howell lana

Rubtzoff

$$
1-1-1-3
$$

Delphinium uliginosum

$1-1-1-3$

Curran

Lepid1um latipes Hook

$$
1-1-1-2
$$

Ranuncul us lobb1i

(Hiern.) Gray

$$
1-1-1-2
$$

SPECIES ON DRY OR MOIST SITES

(nonserpentine)

Amsinckia lunaris Macbr. .

$1-1-1-3$

Antirrhinum virga Eastw.

$1-1-1-3$

Arabis modesta Roll.

$2-1-1-2$

Astragalus brewer1 Gray

$1-1-1-3$

Astragalus clevelandi1

$1-1-1-3$

Calyptridium quadripetalum Wats.

$$
1-1-1-3
$$

Calochortus pulchellus

Dougl ex Benth

$$
1-1-1-3
$$

Ceanothus purpureus Jeps.

$$
1-1-1-3
$$

Collinsla greene1 Gray

$$
1-1-1-3
$$

Eriogonum caninum (Greene)

$$
1-2-1-3
$$
Munz.

Erigeron petrophilus

$$
1-1-1-2
$$

(Greene)

Euphorbla ocellata Dur. \&

$$
1-1-1-3
$$

H11g. var. Rattani1

(Wats.) Wheeler

Fritillaria pluriflora 
Rare Plant Status

Habitat/Species

Lilium rubescens

Wats.

Lomatium ciliolatum Jeps. var. hooveri Math \&

Const.

Lomatium repostum (Jeps.) Math.

Lupinus sericatus Kel.

Mimulus nudatus Curran ex. Greene

Monardella viridis Jeps. ssp. viridis

Pityopus californicus (Eastw.) Copel.

Ribes victoris Greene

SPECIES ON SERPENTINE SITES

Asclepias solanoana Woodson

Calamagrostis ophitidis (Howe11) Nyg ren

Collomia diverstfolia (Greene)

Cryptantha hispidula Greene ex. Brand

Fritillaria purdyi Eastw.

Hesperolinon adenophyllum (Gray) Smali

Hesperolinon bicarpellatum (H.K. Sharsm.) H.K. Sharsms.

Navarettia jepsonil Balley ex. Jeps.

Nemacladus montanus Greene

Senecio clevelandi1 Greene

$$
\begin{gathered}
\text { CNPS }^{1} \text { R-E-V-D } \\
1-1-1-2 \\
1-1-1-3
\end{gathered}
$$

USFWS $^{2}$

State $^{3}$

$$
1-1-1-3
$$

$1-1-1-3$

$1-1-1-3$

$1-1-1-3$

$1-2-1-2$

$$
1-1-1-3
$$

$1-1-1-3$

$1-1-1-3$

$1-1-1-3$

$1-1-1-3$

$1-1-1-3$

2

$1-1-1-3$

2

$1-1-1-3$

$1-1-1-3$

$1-1-1-3$ 
TABLE 6

OFFICIAL STATUS OF PLANTS RARE

IN CALIFORNIA BUT COMMON ELSEWHERE

\begin{tabular}{|c|c|c|c|}
\hline \multirow[b]{2}{*}{ Hab1tat/Species } & \multicolumn{3}{|c|}{ Rare Plant Status } \\
\hline & CNPS $^{1}$ R-E-V-D & USFWS $^{2}$ & State $^{3}$ \\
\hline SPECIES ON WET SITES & & & \\
\hline Calochortus uniflorus & $1-1-1-1$ & & \\
\hline
\end{tabular}


SYMBOLS FOR TABLES 4,5 , AND 6.

${ }^{1}$ California Native Plant Soclety, Rarity--Endangerment--Vigor--Distribution Code

R (Rarity)

1 - rare, but danger of extinction low

2 - several populations or one large population

3 - one or a few highly restricted populations

E (Endangerment)

1 - not endangered

2 - endangered in a portion of its range

3 - endangered throughout its range

V (Vigor)

1 - increasing or stable

2 - declining

3 - approaching extinction

D (Distribution)

1 - widespread outside California

2 - rare outside California

3 - Callfornia endemic

United States Fish and Wildife Service--Federal Register. The species noted are currently under review as Endangered or Threatened.

1 - Taxa for which the service has sufficient information to support listing as Endangered or Threatened Species.

2 - Taxa for which information indicates probable appropriateness of listing as Endangered or Threatened Species. 
${ }^{3}$ State of California - Native Plant Protection Act

\section{E - Endangered}

R - Rare, but not endangered

T - Threatened

$124 / 125$ 

TABLE 7. BLOOMING TIMES OF RARE PLANTS IN THE KGRA*

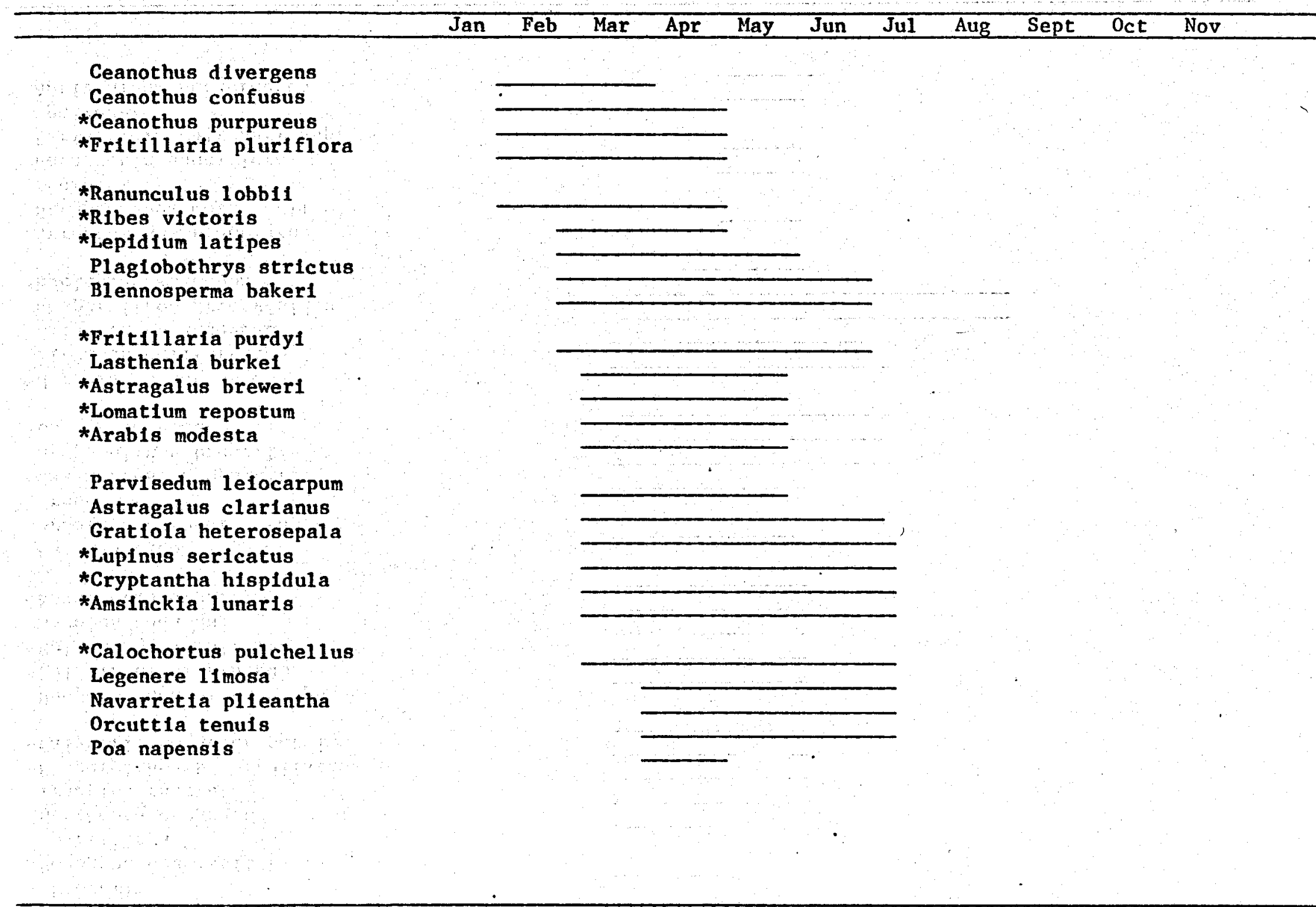




Jan Feb Mar Apr May Jun Jul Aug Sept Oct Nov

*Lomatfum c1liolatum var. hoover1

Pogogyne douglasti ssp. parviflora

Lasthenfa conjugens

Tracylna rostrata

* Hesperolinon bicarpellatum

*Calyptridium quadripetalum

Hesperolinon didymocarpon

*Delphinium uliginosum

*Collomia diversifolla

* Mimulus nudatus

* Navarretia jepsonil

Carex albida

Brodlaea coronarla ssp. rosea

*Calamagrostis ophiditis

Hesperolinon breweri

*Collinsla greene1

*Nemacladus montanus

*Pityopus californicus

Erlastrum brandegeae

Hesperolinon drymarioldes

*Asclepias soloanoa

Streptanthus brachiatus

Streptanthus morrisonil

complex

Navarretia pauciflora

Perideridia galrdneri ssp.

galrdneri

Antirrhinum subcordatum
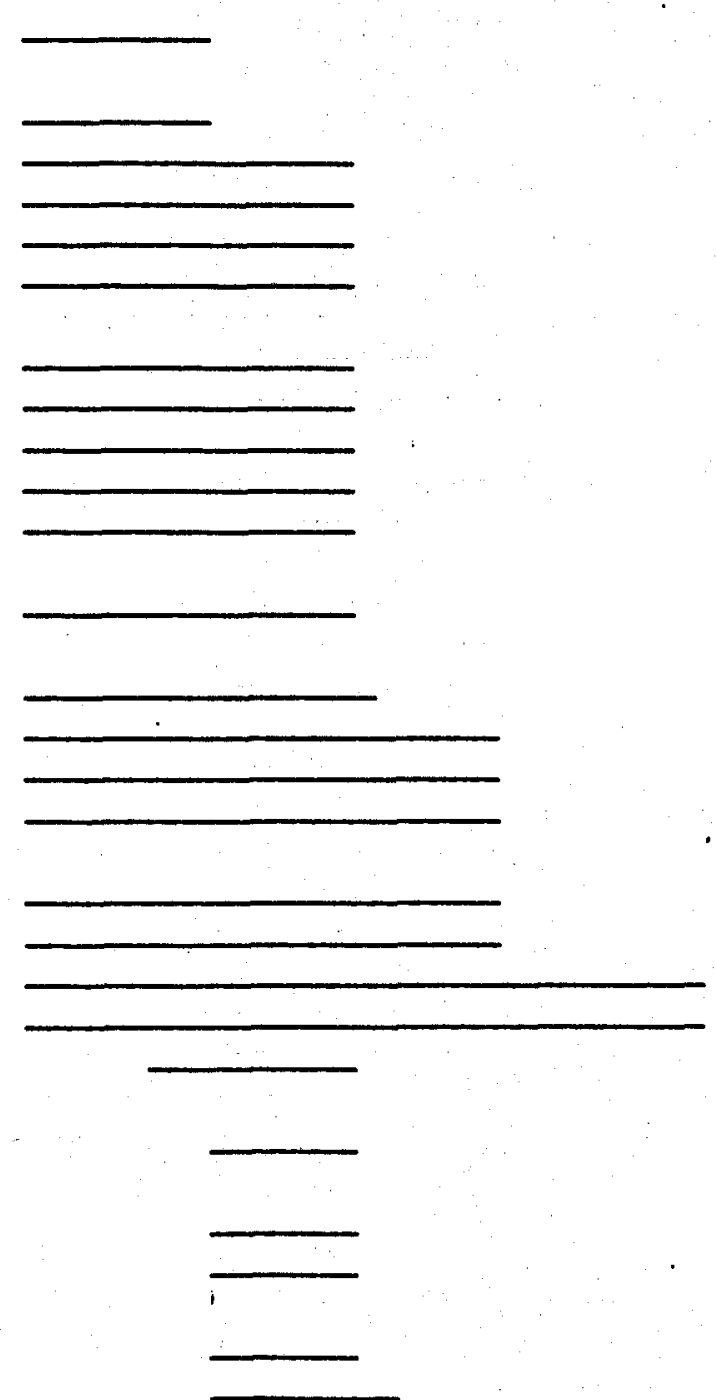
*Antirrhinom virga

Cordylanthus tenuis ssp.

capillaris

*L111um rubescens

* Senecio clevelandil

I Dicanthelium acuminatum var. acuminatum

* Hesperoilnon adenophyllum

Erlogonum nervulosum

*Cuscuta Howelliana

*Astragalus clevelandil

Sidalcea oregana

ssp. hydrophila

*Erlogeron peterophilus

*Monardella viridis ssp.

virdis

Helianthus ex111s

A11 plants are CNPS List 2 (Rare and Endangered) unless noted with (*). These plants are CNPS List 3 (Rare, but not Endangered).

1. Panicum thermale--Taxonomic changes acknowledged, species remains ilsted pending determination of its rarity status. 

REFERENCES

California Native Plant Soclety. Maps of rare and endangered vascular plants of California.

California Native Plant Soclety. Rare plant status reports.

California Natural Diversity Data Base. Map file. Callizo, J. 1979. Rare and endangered plants of Napa County.

Lacey, J. 1981. Department of Water Resources, Report of Communication.

Munz, P.A. 1959. A Callfornia Flora. In collaboration with D.D. Keck. University of California Press. Berkeley. 1681 pp.

Munz, P.A. 1968. Supplement to a California Flora. University of California Press. Berkeley. 224 pp.

Smlth, Jr., J.P., et al. 1980 Inventory of Rare and Endangered P1ants of Cal1fornia. California Native Plant Society. Berkeley. 116 pp.

Smith, J.P. Jr, et al. 1980 Inventory of Rare and Endangered Vascular Plants of California, First Suppl ement. Berkeley. 28 pp.

State of California. 1980. Inventory of the threatened flora of California.

United States Fish and Wild1ife Service. 1980. Federal Register. 
Appendix C

VERTEBRATE ANIMAIS

OF THE GEYSERS KGRA 
MAMMALS:

Opossum

Vagrant: shrew

Ornate shrew

Water shrew

Trowbridge shrew

Western mole

Shrew mole

Little brown myotis

Fringed myot is

California myotis

Hairy-winged myot is

Long-eared myotis

Yuma myotis

Silvery-haired bat

Hoary bat

Red bat

Big brown bat

$\rightarrow$ Pallid bat

$\vec{\omega}$ Townsend's b1g-

eared

tazee-

talled bat

Black-talled hare

Audubon cottontail

Brush rabbit

Beechey ground

squirrel

Sonoma ch ipmunk

Hestern gray squirre

Botta pocket gopher

Heermann kangaroo rat

Western harvest mouse

Brush mouse

Pinyon mouse

Deer mouse

Dusky-footed moodrat

California meadow

mouse

Porcupine

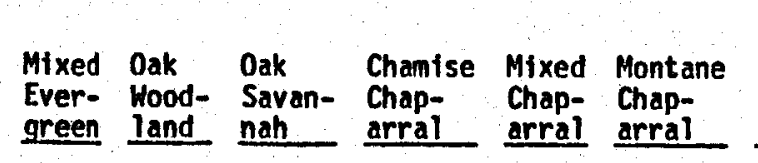

Serpen-

tine Knob-

green land nah arral arral arral arral

cone

Pine Forest Pellow

Pine forous Ripar-

ferous Ian Meadow

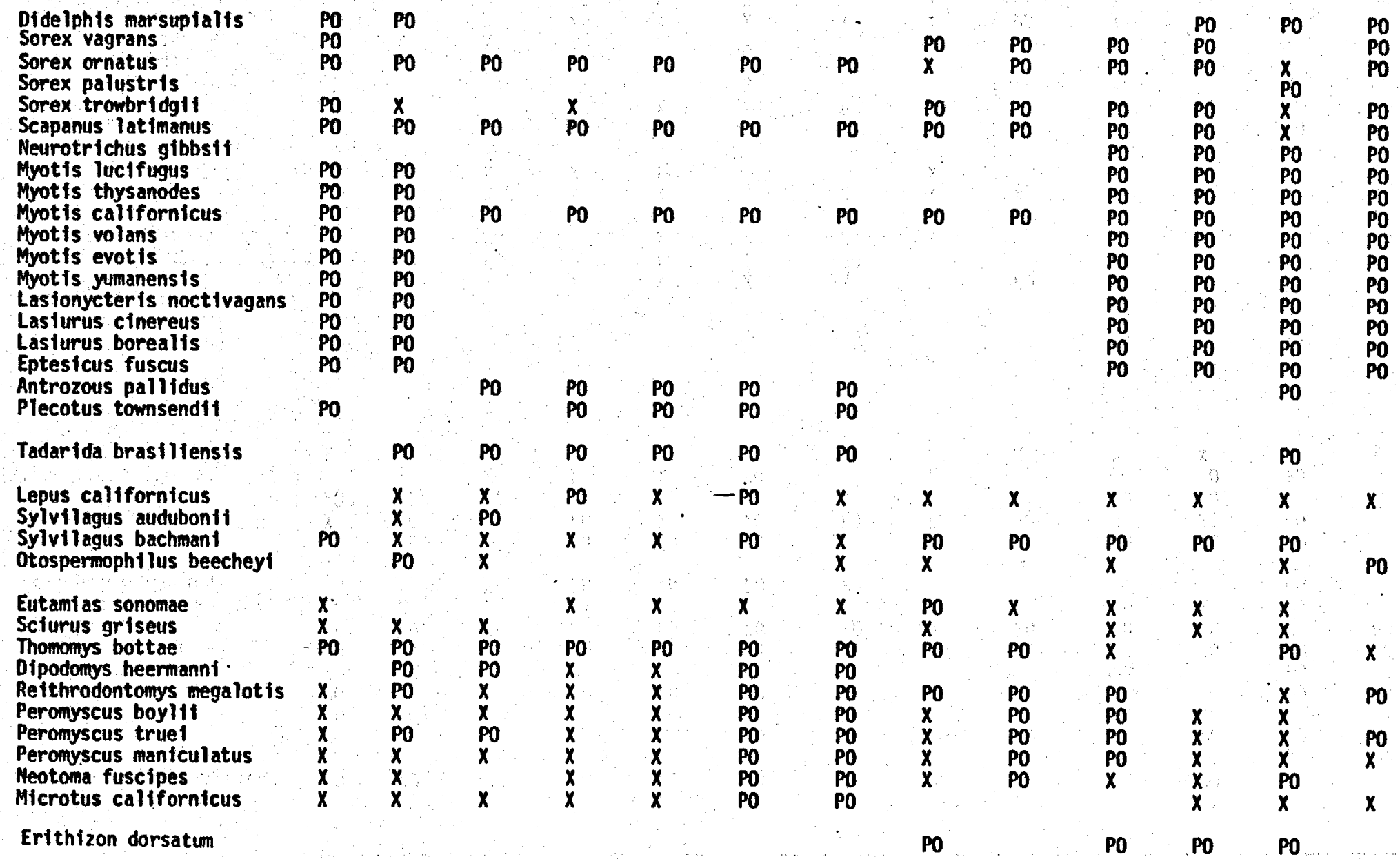


MAMMALS: - contd.

Gray fox

Black bear

Coyote

Raccoon

Mink

Long-tailed weasel

Badger

Striped skunk

Spotted skunk

River otter

Mountain lion

Feral domestic cat

Bobcat.

Wild boar

Black-talled deer

ॅू BIRDS:

Pied-billed grebe Great blue heron Mallard

Turkey vulture

White-tafled kite

Sharp-shinned hawk

Cooper's hawk

Red-tailed hawk

Red-shouldered hawk

(red bellied)

Rough-legged hawk

Golden eagle

Peregrine falcon

Pratrie falcon

American kestrel

Callfornia quail

Mountain quail

American coot

Killdeer
Mixed Oak Oak Chamise Mixed Montane Serpen-

Mixed Oak Oak Chamise Mixed Montane tine Knob- Mixed

Ever- Wood- Savan- Chap- Chap- Chap- Chap- Cone Cypress Yellow Coni- Ripar-
green land nah arral arral arral arral Pine Forest Pine ferous ian

Meadow

\section{Ursus mericanus}

Canis latrans

Procyonlotor

Bassar iscus astutus

Mustela vison

Mustela frenata

Taxidea taxus

Mephitis mephitis

Spllogale putorfus

Lutra canadensis

Felis concolor

Felis domestica

Lynx rufus

Sus scrofa

Odocoileus hemionus

\begin{tabular}{|c|c|c|c|c|c|c|}
\hline PO & PO & PO & PO & PO & PO & PO \\
\hline \multirow{2}{*}{$\begin{array}{l}\text { PO } \\
\text { PO } \\
\text { PO }\end{array}$} & \multirow{2}{*}{$\begin{array}{l}P 0 \\
P 0\end{array}$} & $P O$ & $P O$ & $x$ & $P O$ & PO \\
\hline & & $\cdot$ & PO & $P O$ & PO & PO \\
\hline \multirow{2}{*}{$\begin{array}{l}\mathrm{PO} \\
\mathrm{PO} \\
\mathrm{PO}\end{array}$} & \multirow{2}{*}{$\begin{array}{l}\text { PO } \\
\text { PO } \\
X\end{array}$} & $\begin{array}{l}P 0 \\
P O\end{array}$ & $\begin{array}{l}\text { PO } \\
\text { PO }\end{array}$ & $\begin{array}{l}P 0 \\
P O\end{array}$ & $\begin{array}{l}P 0 \\
P O\end{array}$ & $\begin{array}{l}P O \\
P O\end{array}$ \\
\hline & & $\hat{\mathrm{PO}}_{0}$ & PO & PO & PO & PO \\
\hline $\begin{array}{l}X \\
\text { PO }\end{array}$ & $\begin{array}{l}P O \\
P O \\
P O \\
X\end{array}$ & $\begin{array}{l}X \\
\text { PO } \\
X\end{array}$ & $\begin{array}{l}P 0 \\
P 0 \\
P 0 \\
X\end{array}$ & $\begin{array}{l}P 0 \\
x \\
x \\
x\end{array}$ & $\begin{array}{l}P O \\
P O \\
P O \\
P O\end{array}$ & $\begin{array}{l}P 0 \\
P O \\
X\end{array}$ \\
\hline$x$ & $\ddot{x}$ & $\ddot{x}$ & $\ddot{x}$ & $x$ & $x$ & $x$ \\
\hline
\end{tabular}

$\begin{array}{lll}P O & & P O \\ X & & X \\ P O & P O & X \\ P O & & P O \\ & & P O \\ P O & P O & P O \\ P O & P O & P O \\ P O & & P O \\ & & \\ P O & & P O \\ P O & P O & X \\ X & & P O \\ P O & & X \\ X & X & X\end{array}$

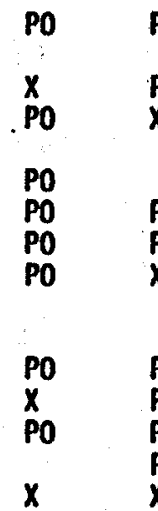

$\begin{array}{lll}P O & P O & P 0 \\ & X & P O \\ P O & P O & P O \\ X & X & \\ & P O & X \\ & P O & \\ P O & P O & P O \\ P O & P O & P O \\ X & P O & \\ & P O & \\ & X & \\ P O & P O & \\ P O & P O & \\ P O & X & \\ P O & P O & \\ X & X & X\end{array}$

Podilymbus podiceps

Ardea herodilas

Anas platyrhynchos

Cathartes aura

Elanus leucurus

Accipiter striatus

Accipiter cooperit

Buteo jamalcens is

Buteo Iineatus

Buteo lagopus

Aquila chrysaetos

Falco peregrinus

Falco mextcanus

Falco sparverius

Lophortyx californicus

Oreortyx pictus

Fullica americana

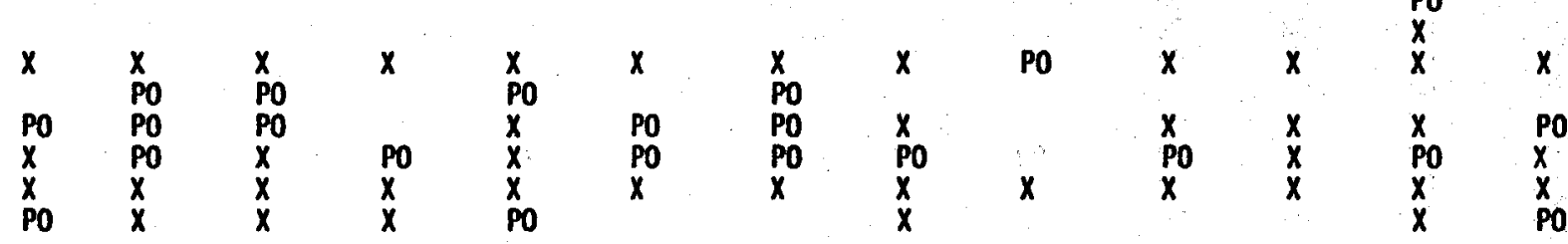

$\begin{array}{rll}X O & P O & P O\end{array}$

$\begin{array}{llllll}X & x & X & P & P O & P O\end{array}$

$\hat{x}$

$\dot{x}$

$x$
$x$
po $x$
$x$
$x$

$\mathbf{p 0}$
$\mathbf{x}$
$\mathbf{x}$
$\mathbf{x}$ 
BIROS: - contd.

Band-talled pigeon Mourning dove

Barn owl

Screech on 1.

Great-horned ow

Pygmy ow 1

Long-eared ow 1

San-whet ow 1

Poor-wtll

Black swift

Vaux's swift

Anna's humingbird

Rufous humingbird

Allen's humingbird

Call tope humingbird

Belted kingf isher

Common flicker:

Pileated woodpecker

Acorn woodpecker

Lewis' moodpecker

$\rightarrow$ Yetlow-belli

Hatry moodpecker

Downy moodpecker

Nuttall's wodpecker

Hestern kingbird

Ash-throated

flycatcher

Black phoebe

Dusky flycatcher

Willow fiycatcher

Western fiycatcher

Western wood pewee.

olive-sided flycatcher

Horned lark

Violet-green swallow

Tree swallow

Rough-winged swallow

Barn swallow
Columba fasciata

Zenaida macroura

Tyto alba

Otus asio

Bubo virginianus

Glaucidium gnoma

Asio otus

Aegollus acadicus

Phalaenoptilus nuttallit

Cypselotdes niger

Chaetura vauxi

Calypte anna

Selasphorus rufus

Selasphorus sasin

Stellula calliope

Megaceryle alcyon

Colaptes auratus

Dryocopus plleatus

Melanerpes formicivorus

Mel anerpes lewi

Sphyrapicus varius

Picpides villosus

Picpides pubescens

Picpides nutallif

Tyrannus verticalis

Mytarchus cinerascens.

Sayornts nígrtcans

Empidonax oberholser

Empidonax tralliti

Empidonax diffictlis

Contopus sordidulus

Nuttallornis borealis

Eremophila alpestris

Progne subts

Tachycineta thalassina

Iridoprocne bicolor

Ste lgidopteryx ruf icol11s

Hirundo rustica
Mixed Oak Oak

Ever- Hood- Savan- Chantse Mixed Montane

green land nah Chap-

Chap- Chap-

tine Knob-

Chap-

cone

ine Forest

Cypress Yellow

Pine

Mixed

ferous Ian

Meadow

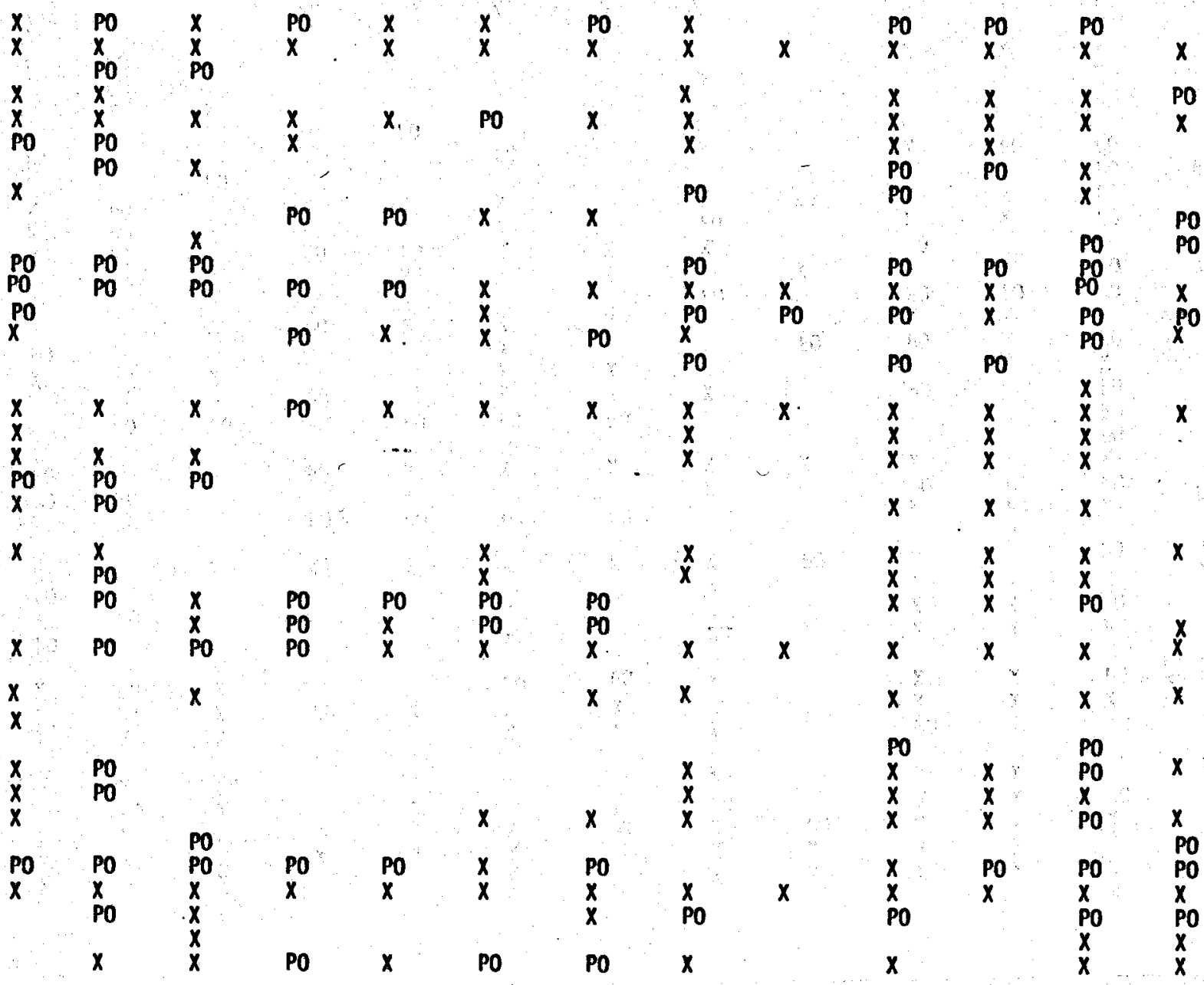


Mixed Oak Oak Chamise Mixed Montane tine Knob-
Ever- Hood- Savan- Chap- Chap- Chap- Chap- Cone Cypress Yellow Coni- Ripar-
green land nah

BIRDS: - contd.

cliff swallow

Stellar's jay

Scrub Jay

Common raven

Common crow

Chesnut-backed

chickadee

Plain titmouse

Bushtit

White-breasted

nuthatch

Red-breasted nuthatch

Pygmy nuthatch

Brown creeper.

Hrentit

Dipper (water ouzel)

House wren

$\vec{w}$ Hinter men

on Bewtck's wren

Rock wren

Mockingbird

Californta thrasher

American robin

Varied thrush

Hermit thrush

Swainson's thrush

Western bluebird

Blue-gray gnatcatcher

Ruby-crowned kinglet

Water pipit

Cedar waxwing

Loggerhead shrike

Starling

Hutton's vireo

Solitary vireo

Warbling vireo

Orange-crowned warbler

Nashville warbler

Yellow warbler

Petrochelidon pyrrhonota

Cyanocitta stelleri

Aphelocoma coerulescens

Corvus corax

Corvus brachyrhynchos

Parus rufescens

Parus Inornatus

Psaitriparus minimus

sitta caroinensis

Sitta canadensis

Sitta pygmaea

Certhia familiaris

Chamaea fasctata

Cinclus mexicanus

Troglodytes aedon

Troglodytes troglodytes

Thryomanes bewickif

Salpinctes obsoletus

Mimus polyglottos

Toxostoma redivivum

Turdus migratorius

Ixoreus naevius

Catharus guttatus .

Catharus ustulatus

Sfalia mexicana

Polioptila caerulea

Regulus satrapa

Regulus calendula

Anthus spinoletta

Bombycilla cedrorum

Lanius ludovicianus

Sturnus vulgaris

Vireo huttoni

Vireo solitarius

Vireo gilvus

Vermivora celata

Vermivora ruficapill

Dendrolca petechia

$\begin{array}{ll}X & X \\ X & X \\ P 0 & P O \\ X & P O \\ X & X\end{array}$

$\underset{x}{x}$

$x$

$x$
$x$
pO

PO

$\begin{array}{lll}x & & x \\ x & x & x \\ x & x & x \\ x & x & x \\ x & x\end{array}$

PO

$P 0$
$P$

$X$
PO
$X$

PO PO

PO

$\begin{array}{rrr}\text { PO } & \text { PO } & \text { PO } \\ \times & x & \times\end{array}$

$\stackrel{x}{\text { P0 }}$

$\begin{array}{llll}x & x & X & \\ x & p O & \end{array}$

PO $\quad \begin{aligned} & x \\ & \text { PO }\end{aligned}$

PO

$P 0 \quad X$

PO

P0

PO

PO

$\hat{x}$
PO

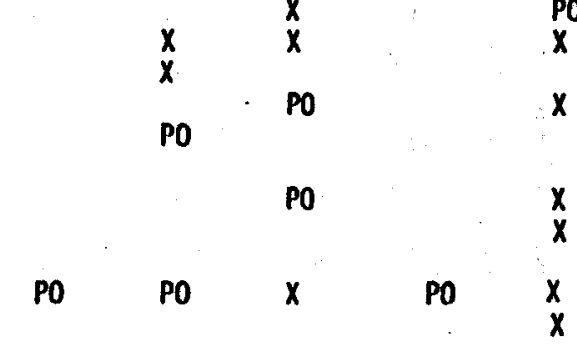

PO PO PO

PO

$P O$
$X$

$\begin{array}{ll}P 0 & x \\ x & x\end{array}$

$x \quad \begin{aligned} & x \\ & \text { PO }\end{aligned}$

$\begin{array}{lllll}x & x & x & x & x \\ x & x & x & x & x \\ p 0 & x & x & x & x \\ x & x & x & p 0 & p 0 \\ x & x & x & p 0 \\ x & p O & x & x & x \\ & x & x & x & x \\ & x & x & \text { PO } & x\end{array}$

PO

$\begin{array}{lll}x & x & P 0 \\ x & x & P 0 \\ x & x & X\end{array}$

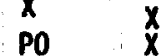

$x$

PO $x$ P $x$

$\begin{array}{lll} & X & P O \\ X & P_{0} & P 0 \\ X & P O\end{array}$

$X 0$
$P O$

PO

P0

$X$
$P 0$

$x$

$x$

Po

$x$
$P 0$
$x$

$x$
$x$

$x$

PO

PO

$x$
$x$
$x$
$x$
$x$ 


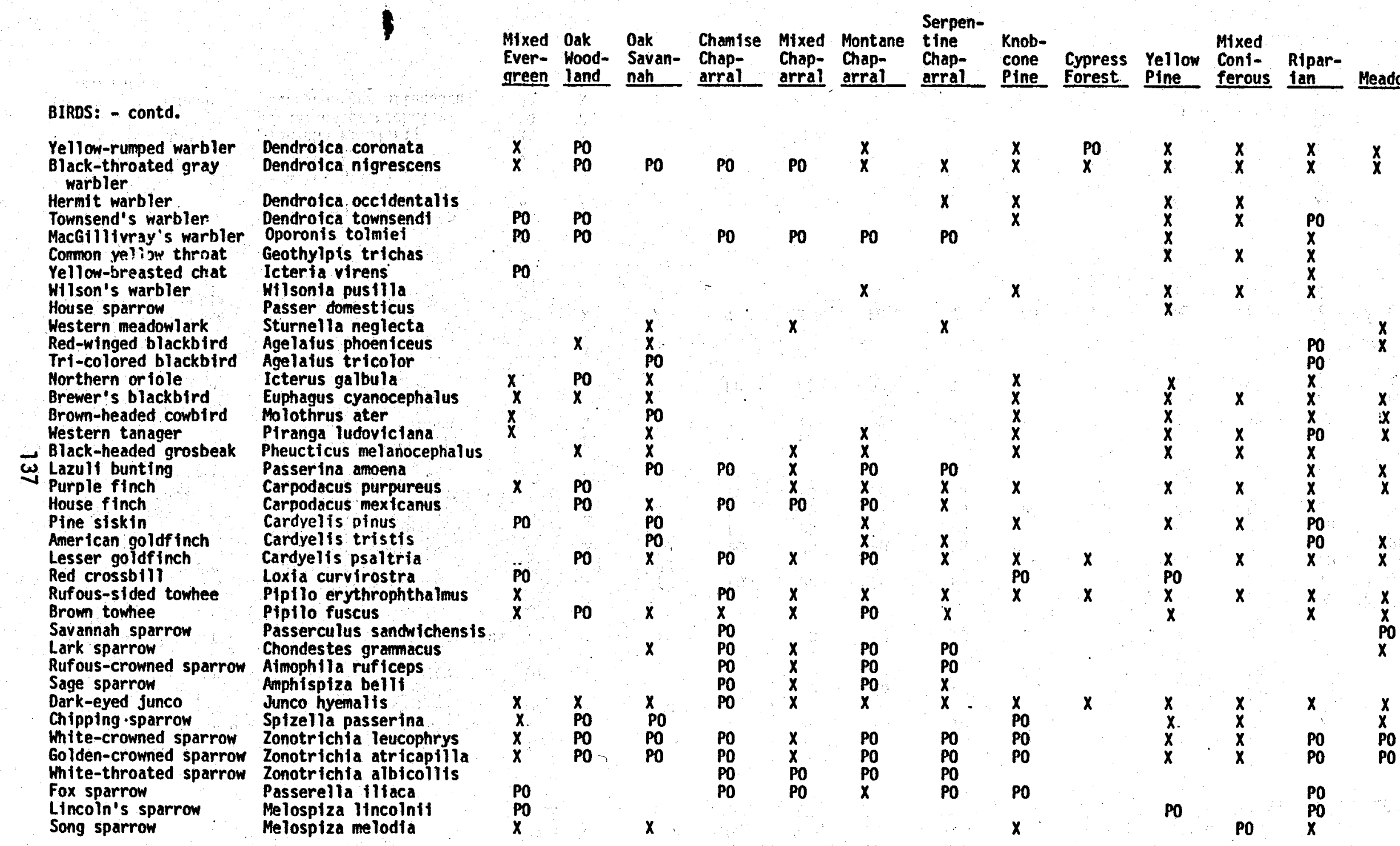


REPTILES:

Sagebrush 11zard Western fence lizard

Western skink

Western whiptail

Northern alligator lizard

Southern alligator 1 izard

Rubber boa

Racer

Sharp-tailed snake

Ringneck snake

Coachwhip

Comon kingsnake

Long-nosed snake

- California mountain

$\omega$ kingsnake

Str1ped racer

Gopher snake

Comon gopher snake

Western terrestrial

garter snake

Western aquatic

garter snake

Western rattlesnake

Western pand turtle

AMPHIBIANS:

Pacific giant

salamander

Rount-sk inned newt

California newt

Red-bellied newt

Ensatina

California siender

salamander
Mixed Oak Oak Chamise Mixed Montane
Ever- Hood- Savan- Chap- Chap- Chaparral green land nah arral

Serpen-

tine Knob-

Chap-

cone

arral

Cypress
Forest

Yellow Cont-

Pine Cont- Ripar

Pine ferous Ian Meadow

Sceloporus occidentalis

Eumeces skiltonianus

Cnemidophorus tigris

$\begin{array}{ll}x & P 0 \\ X & X \\ P 0 & P O\end{array}$

Gerrhonotus coeruleus

$x$
po

PO PO

$\begin{array}{ll}X & P O \\ \text { PO } & P O\end{array}$

PO $\quad X$

$\begin{array}{ll}x & x \\ \text { PO } & x\end{array}$

Gerrhonotus multicarinatus $x$

Charina bottae

Coluber constrictor

Contia tenuis

Diadophis punctatus

Masticoph is flagellum

Lampropeitis getulus

Rhinochellus lecontei

Lampropeitis zonata

Masticophis lateralis

Pituophis melanoleucus

Thamnophis sirtalis

Thamnophis elegans

Thamnophis coucht

Crotalus viridis

Clemys marmorata

$\begin{array}{ll}x & x \\ x & x\end{array}$

$\begin{array}{lllllll}P O & X & X & P O & P O & P O & P O\end{array}$

$\begin{array}{lllll}X & X & & & \\ X & P O & P O & P O & P O\end{array}$

$P O P O$

$\begin{array}{lllll}X & X & X & P O & P O \\ P O & P O & P O\end{array}$

POPO

PO PO

$x \quad x \quad x \quad x$

$\begin{array}{lll}X & X & X \\ P O & P O\end{array}$

$\begin{array}{ll}P O & P O \\ P O & P O\end{array}$

$x$

$x \quad x$

$\begin{array}{llllll}P 0 & P O & P O & P O & P 0 \\ X & X & X & X & P O & P 0\end{array}$

PO $x$

$x$

PO

PO

$x$

$x \quad x \quad \frac{x}{x}$

PO
PO

PO

PO

$\begin{array}{ll}P O & P O\end{array}$

PO PO $X$

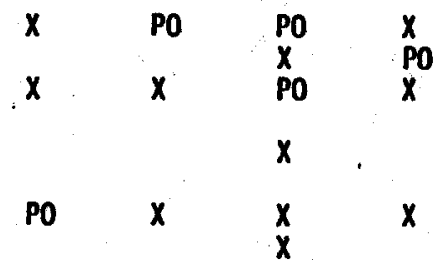

Dicamptodon ensatus

$\begin{array}{ll}x & x \\ x & x \\ x & x \\ x & x \\ \text { PO } & \text { PO } \\ \text { PO } & x\end{array}$

$x$

$x$

Taricha granulosa

Taricha torosa

Taricha rivularis

Ensat ina eschscholtzi

Batrachoseps attenuatus

PO

PO

$x$
$x$
$x$
$P 0$ $x$
$x$
0
0
0
$x$
$x$

P

PO

PO




Mixed Oak Oak Chamise Mixed Montane tine
Ever- Hood- Savan- Chap- Chap- Chap- Chap- Con-
green land nah arral arral arral arral P

Knob-

Cypress Yellow Coni- Ripar-

ine

AMPHIBIANS:

Arboreal salamander

Black salamander

Western toad

Aneides lugubris

Aneides flavipunctatus

Bufo boreas

$\begin{array}{ll}\text { PO } & \text { PO } \\ \text { PO } & \text { PO }\end{array}$

Hyla regilla

Bullfrog Rana catesbelana

Red-legged frog

Foothili yellow-

Rana aurora

Rana boylel

PO PO

PO PO PO

PO

Po $\quad \begin{array}{ll}x & p 0 \\ x & x \\ x \\ x\end{array}$

\section{$X$ - Known Occurrence (Sightings)}

P0 - Probable Occurrence (From Other Reports)

$\vec{\omega}$

Source: Meneghin, et al., 1978. 

Appendix D

IISTING OF POLLUTION INCIDENTS

AT THE GEYSERS GEOTHERMAL FIEID

$141 / 142$ 



\section{IISTING OF POLLUTION INCIDENIS AT THE \\ GEYSERS GEOTHERMAL FIEID}

11/3/65 Discharge of power generation wastewater into Big Sulphur Creek.

11/28/67 Siltation into Big Sulphur Creek from road building activities.

1/4/68 Unusual milky/soapy substance causing turbidity in Big Sulphur Creek from confluence with Squaw Creek to within $\frac{1}{4}$ mile of Russian River.

1/5-6/68 Drilling muds from Geothermal Resources Rorabaugh \#2 found spilling into Big Sulphur Creek. Samples of "Magcogel" and Magcobar Foam \#44" obtained. Bioassays indicated Magcobar 44 toxic to trout at concentration of $10 \mathrm{ppm}$.

1/11/68 Sumps for GRI wells Rorabaugh \#2 and \#3 filled, earthen dams soft. Investigators felt they presented a threat to Big Sulphur if rains continued.

10/2/68 Reduction of fish food organisms and spawning gravels in area of Union 0 il road construction (PG\&E Units 3 \& 4) (possible violation of Fish and Game Code Section 5650).

10/31/68 Silt and rock introducted to Big Sulphur as a result of road building.

11/13/68 Steelhead trout population downstream from Union Oil Company road reduced to $\frac{7}{4}$ that of July 16, 1968 levels.

$9 / 10 / 71 \quad 20,000$ gallons of cooling tower wastewater and debris discharged to Big Sulphur Creek after pipeline faulure in Union Oil waste-

- water disposal system. Iow-flow condition present in Big Sulphur creek.

7/6/72 Driliing muds and waste materials discharged to Big Sulphur Creek when an earthen sump at a Union 0 il drill site (Hoover Rig E2) broke. Test conducted with drilling mud samples (bantonite clay, tannithin and lignite) indicated these materials can be toxic to fishlife.

4/19/73 Drilling muds and waste materials discharged to squaw Creek as a result of a leaking sump at Union 011 drill site (ottoboni \#10). Seeps of drilling waste materials continued until 23 of April.

$7 / 17 / 73$ Discharge of cooling tower condensate reported and verified by DFG wildlife protection personnel. 
10/73 RWQCB cleanup on Abatement Order No. 73-101 for Geothermal Kinetics, Inc. Rorabaugh \#1 Well. Discharge of sump wastes in tributary to Big Sulphur Creek.

10/73 RWQCB and Abatement Order No. 73-102 for Pacific Energy Corp. Well No. 47. Discharge of drililing wastes to surface of dirt roads will probably result in discharge to Big Sulphur Creek.

12/11/73 Ietter from RWQGB informing PG\&E power plant supervisor of (1) sandblasting materials being discharged at power plants \#1 and \#2. These materials could pass into the waters of Big Sulphur Creek. (2) Trash and garbage dump located at power plants 9 and 10 which had not been approved by the RWQCE. (ref: 12,11,1973 letter to $W$. Pearce, PG\&E plant superintendent from D. Snetsinger RWQCB. RWQCB files).

12/21/73 Recommendations from State WRCB regarding soil erosion and waste disposal at The Geysers state that: "The commonly expedient methods used in pit or sump construction disallows for proper design considerations against potential slope failure and/or the prevention of fluid infiltration into subsurface materials. Percolation of fluids through bedrock fractures could affect the quality of local waters and promote instability of natural or manmade slopes." (ref: 12,21, 1973 Memorandum to Bob Tancreto, California Regional WQCB, Santa Rosa from State WRCB Geologist Gil Torres. RWQCB files).

2/5/74 Division of 0 il and Gas notice of violation regarding unstable and overflowing sump for Union Oil Co. Well No. GDC 20-29.

2/5/74 Division of 0 il and Gas notice of violation regarding unstable, washed out and eroded sump, natural springs draining at base for Union 0 il Co. Well No. IF State 4597.

5/74 Approximately 2,000 gallons of water from the cooling tower basin and 50,000 to 70,000 gallons from the sediment basin emergency overflow drainage system of power plant Unit 5 \& 6 discharged to the ground. Inspection of the plants also found oily discharges from stand pipes as a result of numerous spills from a waste oil and oil storage area. (ref: memorandum 5/28/74 to Tancreto, PC\&EE from D. Salisbury; 6/3/74 letter to BenKor CRWGCB, Santa Rosa from W. Pearce, PG\&E. RWQCB files).

5/15/74 Condensate Iine from Unit $7 \& 8$ pond to Unit 11 broke at the drill rig water tie-in point. The tie-in weld broke, releasing condensate at the rate of $465 \mathrm{gpm}$. The total discharge was estimated at 28,000 gallons. There was a noticeable increase in turbidity in Squaw Creek noted. Parametrix personnel reported electroshocking data show fish to be healthy and active (?) (ref: Union 76 letter 5/22/74 to CRWQCB, Santa Rosa, attn: John Hannum). 

$6 / 3 / 74 \quad 50,000$ to 75,000 gallons of steam condensate spilled from a rup- tured pipe at PG\&E plant \#7. Water from this spill reached Squaw Creek. The spill was reported approximately two months after it happened. (ref: Letter 6/3/74 to CRWQCB from W. Pearce. CRWQCB files).

7/8/74 Spill of detergents into Squaw Creek from Union 0il Co. drilling rig wash water. Tests indicated that the material was toxic to fish.

8/20/74. A discharge of condensate water occurred at cooling tower \#2. The water contained approximately $14 \mathrm{mg} / 1$ of iron in addition to the normal constituents found in the condensate. The high iron concentration was the result of an experiment by PGeE. The discharge reached Big Sulphur Creek and resulted in a red discoloration that persisted for approximately one hour (10 ppm). (ref: memo (interoffice) to Bob Tancreto and Ben Kor from D. Snetsinger 8/21/74. (CRWQCB files).

9/9/74 Mechanical failure of the fiberglass disposal line from Unit 5 \& 6 settling pond discharged 4,500 gallons of condensate into Big Sulphur Creek. A fish kill and excessive siltation was noted. (ref: Union 76 letter 9/19/74 to CRWQCB. CRWQCB files).

$9 / 16 / 74$ A unit $5 \& 6$ settling pond overflow on $9 / 15 / 74$ discharged 45,000 gallons of condensate to Big Sulphur Creek. Improper procedures in water transfer blamed. No fish kill noted, however, parametrix noted a higher than average ammonia and sulfate level present in Big Sulphur Creek. (ref: same as above).

1/6/75 Approximately 50 gallons of No. 2 diesel oil was spilled during routine fueling operations at the ottoboni state well no. 20. The diesel was contained within a berm built for that purpose. Heavy rains overflowed the berm and released the diesel to Squaw Creek. (ref: Union 76 letter explaining the delay in reporting the spill to CRWQB 1/15/75. CRWQCB files).

2/25/75 A water spill @ Horner state well \#1 in Lake Co. released approximately 8,000 gallons condensed steam which had been used for drilling water was pumped onto the ground by accident. The water percolated into the ground and there was no visable signs of contamination noted immediately after the accident. Mr. Pardini noted suds in High Valley Creek. (ref: Union 76 letter 3/17/75 to CRWQB, attn: J. Robertson, RWQCB files).

3/31/75 Blow-out of Union Oil Co. Well No. CDC 65-28. Hillsides near well covered with greenish dust which washed into stream tributary to Big Sulphur Creek.

4/9/75 Construction efforts to control blow-out of Union Oil Co. Well No. GDC 65-28 result in high turbidity and sedimentation of Big Sulphur Creek and tributary (reportedly a continuing problem). 
5/9/75 Discharge of cooling tower water from PG\&E Unit \#11 into Squaw Creek.

$6 / 4 / 75$ A flange broke at Unit 11 spilling an estimated 20,000 gallons of condensate to the ground. Of the amcunt spilled, most was contained in a basin but $10 \%$ was reported to have reached Squaw Creek. The flange is of the same type as installed at other units. (ref: PG\&E letter 6/4/75 to CRWQCB, attn: Mr. Snetsinger; Interoffice memo $6 / 5 / 75$ to B. Tancreto, B. Kor, and D. Snetsinger from D. Salisbury. CRWQCB files).

$6 / 6 / 75$ A spill of 10,000 gallons from Unit 3 consisted of steam condensate and water from a tributary of Big Sulphur Creek. A vitrified clay pipe broke, and drained the water $\frac{1}{2}$ mile down the hill carrying mud into the creek. Duration of the spill was approximately 4 hours. The clay pipe is being replaced with glass lined carbon steel pipe. (ref: PG\&E letter 6/10/75 to CRWQCB, attn. Mr. Snetsinger. CRWQCB files).

8/6/75 Discharge of material from Shell Oil Company Well U.S. Geothermal One-1 on Federal lease, Lake County, Sec. 1, T1ON, R8W, MDB\&M. Grey material discharged from well covered approximately 3-4 acres, coating ground surface; shrubs, and trees. Portion entered intermittent tributary to Dry Creek.

9/5/75 Water was discharged from a Unit 10 cooling tower header pipe flange to the ground. The flange broke during a Unit 10 shutdown releasing 148,500 gallons of steam condensate in 4 minutes. The spill ran down $\frac{1}{4}$ mile of hillside to Cobb Creek and eventually to Big Sulphur Creek. There was no visible damage to fishlife or excess siltation in Big Sulphur Creek noted. (ref. PG\&E letter 9/10/75 to CRWQCB, attn: Mr. Snetsinger. CRWQCB files).

12/75 Spill of drilling mud from PEC well near Eagle Rock Mine. Mud return line broke and discharged to tributary to Big Sulphur Creek.

3/16/76 Condensate pipeline failure at Unit 2 power plant, resulting in discharge of 4,260 gallons. The pipeline was of rebar reinforced concrete and had been badly corroded by the condensate. No extensive fish kill was observed in the stream below the discharge site.

$5 / 26 / 76$ Spill of 4,000 gallons of steam condensate at Unit 11 , with a discharge to Squaw Creek. Spill caused by failure of a check valve in the condensate return line to an injection well. A total of 54 dead steelhead trout were found in a stream section of 200 yards below the discharge.

3/28/77. Single vehicle accident involving Shell Oil Company truck delivering fuel oil to McCulloch Oil Company Geothermal rig near Glenbrook, Lake County. About 2,000 gallons of fuel oil was discharged with approximately 50 gallons entering Alder Creek. Four dead fish observed in lower Alder Creek. 
4/6/77 Spill of 2,500 gallons of steam condensate at PG\&E Geysers Unit 8. Excessive pumping of sediment pond caused low water levels, activated automatic valve which prevented usual discharge. The high water level alarm of the cooling tower basin was inoperative, which resulted in an overflow of the basin of about $250 \mathrm{gal} / \mathrm{min}$ for 10 minutes. The condensate discharged into Upper Geyser Canyon Creek, but apparently did not reach Big Sulphur Creek. The condensate soaked into ground which was dry as a result of drought conditions.

4/18/77 Fajlure of cut slope during Union 0il 1Co. road construction resulted in slide of soil, rocks, and debris entering Big Sulphur Creek above Unit 1 \& 2. Road was being Improved for access to Unit 14. Substation pool area filled, and siltation of stream. Stream was highly turbid when inspected on May 2, due to runoff from recent storm.

4/19/77 Spill of 25,500 gallons of condensate at Geysers Power Plant Unit 11. Water was discharged from the cooling tower into Squaw Creek. The cooling tower basin was being filled unatterded during the night and the overflow alarm did not provide sufficient warning. Duration of the spill was approximately 45 minutes.

5/6/77 Large landslide at site of construction of Geysers Power Plant Unit 14. Slide occurred in cut slope for cooling tower basin. Site was not as stable as had been believed. A portion of the slide entered an adjacent tributary to Big Sulphur Creek, depositing soil, rocks, debris, and trees and shrubs filled by the slide.

5/16/77 Spill of 3,750 gallons of condensate from Geysers Unit 1 \& 2 into Big Sulphur Creek. Discharge resulted from a blockage in the condensate line between the cooling tower basin and the sedimentation basin. The spill was probably related to recently-installed fine mesh screen strainers.

$6 / 2 / 77$ Discharge of 250,000 gallons of condensate from Unit 8 to Big Sulphur and Squaw Creeks, streams turbid and heavily sedimented below discharge sites. No fish kill observed, however, population sampling revealed a lack of young-of-the-year resident rainbow trout in Squaw Creek below discharge site. Young fish were found here in the previous year's survey and in the area above the discharge point.

6/28/77 Spill of 850 gallons condensate at Unit 9. Rupture in fire water system, did not reach Cobb Creek below the site.

$1 / 78$

Landslide at Unit 14 site into tributary of Big Sulphur Creek. Landslide at Geyser Canyon, tributary of Big Sulphur Creek. Landslide at Unit 14 supply well, entered Big Sulphur Creek. Sedimentation and turbidity. 
Improvement of road from Unit 14 site, through Little Geysers Area, to Unit 9 and 10 . Replacement of culvert crossing at little Geysers Creek. Repair of numerous failures of cut slopes along roadways. Big Sulphur Creek highly turbid below Iittle Geyser Creek, clear above.

$1 / 21 / 78$

$2 / 28 / 78$

Spill of 500 gallons acid ferrous sulfate into Lee Creek, Lake County. Result of tanker vehicle accident. Substance is used in $\mathrm{H}_{2} \mathrm{~S}$ abatement process. Salamanders killed in Lee Creek.

Spill of 50,000 gallons condensate at Unit 8. Tekite pipe containing condensate from cooling tower basin ruptured. Discharged to Geyser Canyon, thence Big Sulphur Creek. Turbidities increased, no fish kill observed.

$3 / 10 / 78$

Overflow pipe observed discharging petroleum/water mixture to tributary, Lake County. Aminoil Co. drilling site near PG\&E's Unit 13. Reported by J. Henno, Central Valley Regional Water Quality Control Board, Sacramento. Foreman on site requested to discontinue discharge.

4/11/78 Spill of 100,000 gellon condensate at Unit 8. Same cause as spill of $2 / 28$. No fish $\mathrm{kill}$ reported.

$5 / 1 / 78$

$5 / 28 / 78$

$6 / 1 / 78$

Discharge 2,000 gallon condensate at Unit 1 for 5 minute period. 1,000 gallons entered Big Sulphur Creek.

Spill of 200 gallon condensate to Big Sulphur Creek from Unit 1 over a 6 minute period, no assessment of stream.

At 0640 spray jets at Unit 5 and 6 cooling tower plugged, and the condensate discharged into the area around the tower in a heavy rain. The discharge continued for one hour and an estimated 10 gal/min (600 gal) collected as runoff and entered Big Sulphur Creek. Stream inspected on $6 / 2$ by Steve Miller, PG\&E; no fish kill noted.

6/25/78 At 0700 discharge 3,000 gallon condensate to Big Sulphur Creek. No dead fish. Water samples taken by PGsE.

$7 / 11 / 78$

$1 / 3 / 79$

Spill of 14,000 gallon condensate from pipe rupture at Unit 7 and 8. Spill contained on site or soaked into ground near site.

Spill of 130,000 gallon condensate from Unit 7 into Squaw Creek, little rain to date, stream at low flow conditions. High turbidity and heavy siltation occurred; just prior to steelhead spawning period.

$2 / 1 / 79$

Spill of 15 gallon caustic soda to Big Sulphur Creek. Raised pH from 7.7 to 8.2 . No damage to aquatic life noted by PG\&E personnel. 
5/8/79 Spill at PG\&E Unit 12. Steam condensate discharged into Cobb Creek at 0800 for $20 \mathrm{~min}$. Union 011 closed off too many valves on sediment pond system causing backup and overflow. Alarms at plant site and Unit 5, 6 failed to sound, but w11l be corrected. Water samples were being taken in Cobb Creek and a report will be sent to NCRWQCB. Phone call from Glen Horton, PG\&E.

6/19/79 Discharge of 400 gallons condensate at Unit 4. Stream examined 2 hours after spill; no evidence of loss of aquatic life.

$7 / 16 / 79$ Unit 3 discharged 60,000 gallons condensate to Big Sulphur Creek at $1: 55 \mathrm{a} . \mathrm{m}$.

$7 / 16 / 79$ Spill of condensate from pipeline from Units 5,6 , to Thermal 8 at 7:00 a.m.

$7 / 16 / 79$ Overflow of 1,000 gallons non-sulfide sludge from sump below Unit 11 at 9:30 p.m. No sludge reached stream.

10/79 Extensive fish kill in Big Sulphur Creek. Cause undetermined.

11/28/79 Discharge from sump by Amino1l, Anderson Creek, Lake County. Memorandum of $12 / 11 / 79$ by J.L. Pearson, CVRWQCB.

1/9/80 Discharge by sump Neashon No. 1, Republic Geothermal, Lake County. Memo of $1 / 23 / 80$ by E.E. Crawford, CVRWQCB.

6/80 Tributary from PGandE Unit 13 found to be contributing silt and turbidity to Anderson Creek, Lake County. Revegetation and restoration of sedimentation basin planned by PGandE and Aminoil. Memo of $7 / 18 / 80$ by E.E. Crawford, CVRWQCB.

12/11/80 Discharge of drilling mud from Thermogenics, Inc. sump RA-13 in Sonoma County to roads and drill pads in violation of waste discharge requirements. Memo dated 12-12-80 by B.D. Kor, NCRWQCB.

SOURCE: California Department of Fish and Game, Region III, Yountville, CA. 